Portland State University

PDXScholar

\title{
The attitudes of youth workers on delinquency and delinquency programs
}

\author{
Gary Lee Dominick \\ Portland State University \\ Carol Swartz \\ Portland State University \\ Michael Orval Taylor \\ Portland State University
}

Follow this and additional works at: https://pdxscholar.library.pdx.edu/open_access_etds

Part of the Social Work Commons

Let us know how access to this document benefits you.

\section{Recommended Citation}

Dominick, Gary Lee; Swartz, Carol; and Taylor, Michael Orval, "The attitudes of youth workers on delinquency and delinquency programs" (1977). Dissertations and Theses. Paper 1927.

https://doi.org/10.15760/etd.1926

This Thesis is brought to you for free and open access. It has been accepted for inclusion in Dissertations and Theses by an authorized administrator of PDXScholar. Please contact us if we can make this document more accessible: pdxscholar@pdx.edu. 


\title{
THE ATTITUDES OF YOUTH WORKERS ON DELINQUENCY AND DELINQUENCY PROGRAMS
}

\author{
by
}

GARY LEE DOMINICK

CAROL SWARTZ

MICHAEL O. TAYLOR

\begin{abstract}
A practicum submitted in partial fulfillment of the requirements for the degree of

MASTER Of SOCIAL WORK
\end{abstract}

Portland State University

1977 
TO THE OFFICE OF GRADUATE STUDIES AND RESEARCH:

John F. Longres, Ph. D., and Norman L. Wyers, D.S.W. approve the practicum of Gary Lee Dominick, Carol Swartz, and Michael O. Taylor presented June 1, 1977.
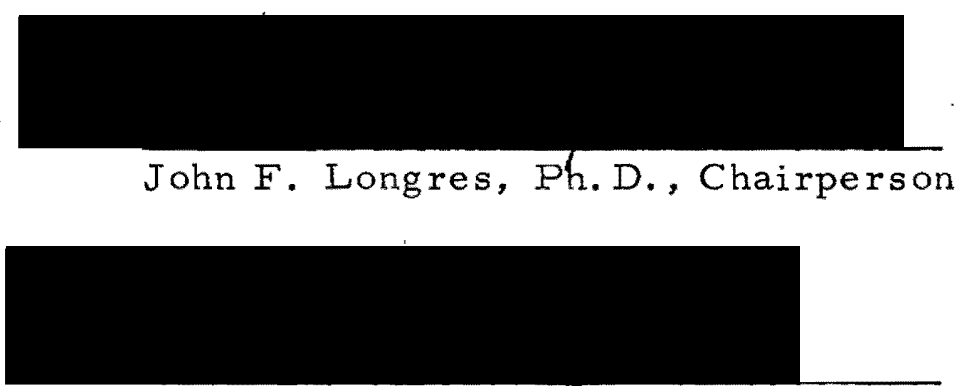

Norman L. Wyers, D. S. W. 
TABLE OF CONTENTS

PAGE

LIST OF TABLES $\ldots \ldots \ldots \ldots \ldots \ldots \ldots \ldots \ldots \ldots \ldots \ldots \ldots \ldots$ vi

LIST OF FIGURES $\ldots \ldots \ldots \ldots \ldots \ldots \ldots \ldots \ldots \ldots \ldots \ldots \ldots \ldots \ldots \ldots$ ix

CHAPTER

I INTRODUCTION AND THEORETICAL

FRAMEWORK $\ldots \ldots \ldots \ldots \ldots \ldots \ldots$

Paradigm I Conservative

Paradigm I Liberal

Paradigm I Radical

Paradigm II Conservative

Paradigm II Liberal

Paradigm II Radical

II REVIEW OF THE LITERATURE ......... 11

Delinquency Theories and Research ... 11

Introduction

Causes of Delinquency

Broad Range Theories

Middle Range Theories

Female Delinquency

Labeling

Delinquency Intervention $\ldots \ldots \ldots \ldots$

Delinquency Intervention Perspectives 
CHAPTER

PAGE

Types of Intervention Programs and

Evaluative Studies...........

Small Scale Intervention

Outreach

Services to Individuals

Group Services

Work Experience

Behavior Modification

Special Education

Adult Model

Large Scale Intervention Programs

Area Improvement

Coordination of Service

Recent Trends in Delinquency Prevention

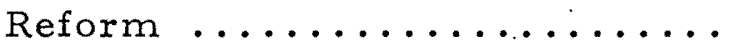

III RESEARCH DESIGN AND METHODOLOGY ...

The Collection of the Data

The Instrument

On the Causes of Delinquency

Program and Policy Considerations

On the Role of the Worker

The Sample

Limitations of the Study

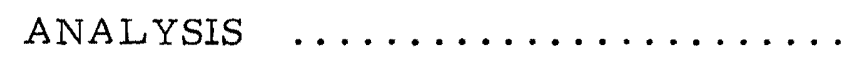

Introduction to Factor Analysis .......

Explanation of Factors $\ldots \ldots \ldots \ldots \ldots$

Factors Relating to the Causes

Factors Relating to Delinquency

Programs

Factors Relating to the Role of the Worker

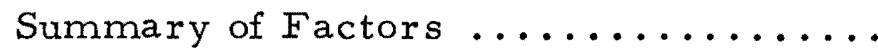


Description of Findings .......... 80

Introduction to Findings
Factors Relating to the Causes of
Delinquency
Factors Relating to Delinquency Pro-
grams
Factors Relating to the Role of the
Worker

Summary of Findings $\ldots \ldots \ldots \ldots \ldots \ldots$. 99

Feedback from Respondents ......... 100

Development of a New Questionnaire .... 100

V SUMMARY AND RECOMMENDATIONS $\ldots \ldots \ldots 102$

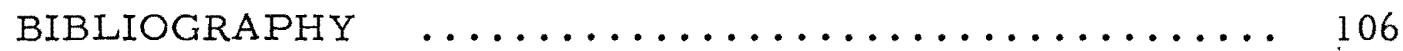

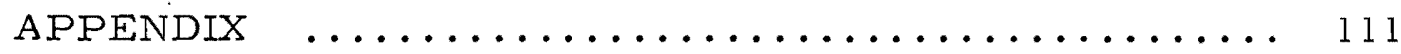

I Original Questionnaire $\ldots \ldots \ldots \ldots \ldots \ldots \ldots, 111$

II Revised Questionnaire $\ldots \ldots \ldots \ldots \ldots \ldots \ldots .135$

III Introductory Letter to Agencies .......... 145 


\section{LIST OF TABLES}

TABLE

PAGE

I Theoretical Orientation $\ldots \ldots \ldots \ldots . \ldots . \ldots . \ldots$

II A. Selected Characteristics of the Sample:

Sex, Age, Socio-Economic Status ...... 52

B. Selected Characteristics of the Sample:

Geographical Background .......... 53

C. Selected Characteristics of the Sample:

Job Satisfaction, Caseload Size,

Type of Agency. .............. 54

D. Philosophical Perspective............ 55

III Dysfunctional Social Structure ........... 59

IV $\quad$ Return to Old Values ................ 60

V Dysfunctional Families ............... 62

VI Bio-Psychological Deficiencies $\ldots \ldots \ldots \ldots 63$

VII Permissive Society ................. 64

VIII Labeling and Political Expression ......... 66

IX Need for Educational Changes $\ldots \ldots \ldots \ldots 7$

$\mathrm{X} \quad$ No Need for Changing Laws Relating to Youth .. 68

XI Direct Family Services ............... 69 
XII Positive Sentiments Toward Individuals'

Ability to Change ............. 70

XIII The Need for Individual and Organizational

Change $\ldots \ldots \ldots \ldots \ldots \ldots \ldots \ldots \ldots \ldots \ldots \ldots$

XIV Cynicism Toward Programs for Youth....... 72

XV Job Preparation $\ldots \ldots \ldots \ldots \ldots \ldots \ldots \ldots \ldots$

XVI Role as Counselors ................ 74

XVII Worker as Activist ................ 75

XVIII Agency Constraints $\ldots \ldots \ldots \ldots \ldots \ldots \ldots$

XIX Return to Old Values ............... 76

$\mathrm{XX} \quad$ Community Involvement $\ldots \ldots \ldots \ldots \ldots \ldots$

XXI Dysfunctional Social Structures $\quad \ldots \ldots \ldots \ldots 2$

XXII Return to Old Values .............. 83

XXIII Dysfunctional Families .............. 84

XXIV Bio-Psychological Deficiencies .......... 85

XXV The Permissive Society $\ldots \ldots \ldots \ldots \ldots$

XXVI Labeling and Political Expression ........ 87

XXVII Need for Educational Change .......... 88

XXVIII No Need for Changing Laws Relating to Youth.. 89

XXIX Family Services $\quad \ldots \ldots \ldots \ldots \ldots \ldots \ldots . \ldots . \ldots$ 
XXX Positive Sentiments Toward Individual's

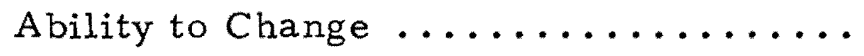

XXXI The Need for Individual and Organizational

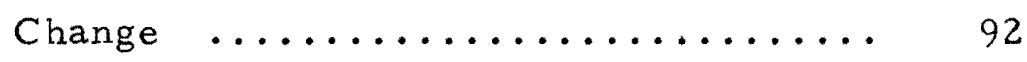

XXXII Cynicism Toward Programs for Youth ...... 93

XXXIII Job Preparation $\quad \ldots \ldots \ldots \ldots \ldots \ldots \ldots$

XXXIV Role as Counselor ................ 95

XXXV Workers As Activists ................ 96

XXXVI Agency Constraints $\ldots \ldots \ldots \ldots \ldots \ldots \ldots$

XXXVII Return to Old Values .............. 97

XXXVIII Community Involvement $\ldots \ldots \ldots \ldots \ldots$ 


\section{LIST OF FIGURES}

PAGE

Figure $1 \quad$ The Nature of Delinquency $\ldots \ldots \ldots \ldots \ldots \ldots$ 


\section{CHAPTER I}

\section{INTRODUCTION AND THEORETICAI FRAMEWORK}

This research developed from our interest in juvenile delinquency. We wished to examine how youth workers think about the causes of delinquency, the structure of delinquency programs, and their own role as workers. These perceptions will be examined by looking at workers' responses to statements dealing with 1) juvenile delinquency causation, 2) programs for treatment and prevention, and 3) the role of the worker. The responses will be examined in the light of a theoretical framework reflecting the continuum between theories and programs based on individual causation and those emphasizing societal factors.

The theoretical framework will categorize the theories which range from those emphasizing the individual to those mainly looking at societal factors. An analysis of textbooks on social problems done by C. Wright Mills in 1943 showed leading theorists emphasized interpersonal, situational determinants of social problems (Mills, 1968). Mills called this emphasis an "ideology of social pathologists" in contrast to an emphasis on the examination of social structural defects. 
This emphasis on the individual is also noted by William Ryan in Blaming the Victim. He describes the negative effect of this practice and the thinking which enables some to entirely forget the effect of normative arrangements. Ryan asserts that "victim blaming" includes theories emphasizing hereditary factors or "innate weakness" as well as:

... the new ideology (which) attributes individual inadequacy to the malignant nature of poverty, injustice, slum life, and racial difficulties. The stigma that marks the victim and accounts for his victimization is an acquired stigma, a stigma of social, rather than genetic, origin. But the stigma, the defect, the total difference - though derived in the past from environmental forces - is still located within the victim, inside his skin... (the humanitarian) can, all at the same time, concentrate his charitable interest on the defects of the victim, condemn the vague social and environmental stresses that produced the defect (some time ago), and ignore the continuing effect of victimizing social forces (right now). It is a brilliant ideology for justifying a perverse form of social action designed to change, not society, as one might expect, but rather society's victim. (Ryan, 1971)

There have been some previous studies in this area, and it was of special interest for us to follow-up a study done by John Longres and Norman Wyers on the attitudes of delinquency program administrators. Their results suggested that administrators of youth programs were overwhelmingly oriented towards theories stressing individual and interpersonal problems and programs calling for changing the individual delinquent. Two other studies 
focused on determining the theoretical perspective of personnel in delinquency programs. Douglas Knight (1972) developed a questionnaire which used statements by delinquency theorists to measure workers' theoretical perspective. This was accomplished by compiling scores of agreement/disagreement with these statements. Cheryl Ruby (1974) used Knights' questionnaire to test the difference in attitudes of workers in traditional vs. diversion programs. Our emphasis was to develop a questionnaire using some of the questions developed in these previous studies. We added statements to reflect more specific categories within the individual-societal continuum.

Roland Warren (1971), in a study on Failures with the War on Poverty, provides the language and perspective for the theoretical framework. He develops two theoretical paradigms which he believes guide the approach to social problems such as poverty and delinquency. Paradigm I assumes that the institutions of society are basically sound. Within this paradigm, the concept of a residual "problem population" is accented. Some youth become delinquent through their own failure, as everyone has the same rights and opportunities. The focus is on individual deficiency. This Paradigm I viewpoint is consistent with attitudes towards causation of other psychological or mental problems which emphasize the individual, whereas in physical illness, there is routinely a search for a causal factor in the environment (Mechanic, 1969). These Paradigm I 
assumptions grew out of our heritage of "rugged individualism," liberalism, individual freedom, competition and the right to private property. Paradigm I values are a part of the institutional foundations of the American society (James, 1972).

Paradigm II maintains that the cause of social problems, such as juvenile delinquency, lie within the structure of society and its institutions, and that structural, not individual, change is necessary to solve these problems (Warren, 1971). This is in direct opposition to the Paradigm I assumptions. In the Paradigm II framework, individual deficiencies are viewed as being systematically produced by structural inadequacies, rather than the inherent defect of the individual. High rates of car thefts among lower-class youth might be seen in the Paradigm I perspective as a lack of "impulse control" while the Paradigm II perspective might view this high rate of theft as the direct result of blocked economic opportunity (Ohlin and Cloward, 1960). Paradigm I views the solution to social problems lying chiefly in the rehabilitation of individuals or groups, whereas Paradigm II theorists view the solution in the restructuring of our major institutions, including. shifts in the balance of power and redistribution of income. The implication is that a Paradigm I perspective emphasizes patching up problems and treating symptoms, while nothing is done to change the basic causal factors; hence, the problems will recur and persist. Changing the broad societal 
determinants is only addressed by the Paradigm II radical perspective articulated by Roland Warren as they relate to juvenile delinquency. We expected to be able to measure the theoretical positions of workers by their responses to statements designed to reflect the dichotomy between Paradigm I and Paradigm II.

In examining these paradigms, it is clear that this dichotomy does not provide for all the perspectives of delinquency causation in the literature nor the variety in programs and practice. There are a number of recent programs that are moving beyong focusing treatment efforts on the individual. There is a need for further elaboration of these two paradigms to adequately reflect the ideas of contemporary line workers regarding juvenile delinquency causation, programs and their perceived role.

Richard Cloward and Frances Piven in their introduction to Radical Social Work also noted that the Paradigm I and II dichotomy does not address other options of working with individuals while maintaining a radical perspective toward social change. They propose workers advocate for individual clients within the bureaucratic systems which employ them so that the clients are not so oppressed by institutionalized social arrangements, thereby truly working for the rights and needs of their clients (Bailey, ed., 1975). Those who emphasize "radical social work practice" state that,"Individual casework does have a place as individuals continue to suffer psycho- 
logical damage from the abuse and oppression of an indifferent or hostile society." It is proposed that "individual casework should help the individual understand his alienation, promote his autonomy, and to assist radical change rather than adjustment." (Baily, 1975) Edwin Schur's work on juvenile delinquency provides us with more theory base for this elaboration of the Paradigm I and II dichotomy. Schur suggests a "radical non-intervention" policy towards juvenile delinquency. He contrasts this proposal with two other policy alternatives - "individual treatment" and "liberal reform." (Schur, 1973)

Schur's analysis of the "individual treatment" approach relates directly to Mill's "ideology of social pathologists." Ryan's "blaming the victim" and Warren's Paradigm I are additional critiques of the view of juvenile delinquency causation theories and treatment efforts which focus on the individual. Schur's discussion of "liberal reform" and "radical non-intervention" are expansions of Mills" "social structural analysis" and Warren's Paradigm II. This explication begins to expand and contrast categories of the Paradigm I/Paradigm II framework to reflect conservative, liberal, and radical socio-political orientations.

We intend to expand the Paradigm I/Paradigm II dichotomy into categories which reflect the socio-political and pragmatic orientations of line workers; to develop a questionnaire of statements 
designed to represent these categories; and then to statistically test whether our statements are perceived to represent these theoretical categories.

Paradigm I Conservative

This category within the personal problem orientation emphasizes biological, genetic or hereditary deficiencies. The intervention strategies are structured and aim to punish and control. The role of the worker is authoritarian and conservative; to use authority to enforce social expectations and teach responsibility.

$\underline{\text { Paradigm I Liberal }}$

This category emphasizes the many psychodynamic, humanistic, and behavioristic theories extant on delinquency. Examples are causation theories emphasizing poor self-image, lack of personal motivation and other personality deficiencies. Intervention strategies are individual psychotherapy, group the rapy, family therapy, adult modeling and behavior modification approaches. Counseling efforts to help clients deal with the society as it is now are emphasized. The worker is seen as teacher, surrogate parent and therapist.

$\underline{\text { Paradigm I Radical }}$

This category reflects those theories recognizing the need for social change but emphasizing a continuing need to work with the 
individual. Workers engaged in "radical social work" including consciousness raising, the formation of self-help action groups and advocacy within the system typify this stance. Programs would emphasize raising the consciousness of delinquents and their families about the ways in which social structural arrangements oppress them. The role of the worker is similar to the liberal orientation but emphasizes the client understanding economic, political, and legal dynamics rather than personal and interpersonal problems.

$\underline{\text { Paradigm II Conservative }}$

This viewpoint within the structural problem orientation emphasizes the contemporary changes in our values about the family, sub-cultures or even society in general as an important cause of delinquency. The assumption is that institutional arrangements of the past caused less delinquency than those of the present. Lack of social control is emphasized. The notion that delinquent subcultures support behavior which is negative and that delinquent behavior is patterned in lower-class cultures are further examples of the need to "return to the old values" to prevent delinquency. Programs and role of the worker are similar to Paradigm I with the worker involved with the individual and the family in an attempt to instill values and structure. 
$\underline{\text { Paradigm II Liberal }}$

Causative theories in this category emphasize dysfunction within organizations which affect youth: the community, the schools and the juvenile courts. Organizational analysis and reform is emphasized rather than broad institutional change. Liberal programs emphasize community development and organization for improvement and self-help. The role of the worker is as community organizer and advocate for the client within existing organizations. The worker involves himself in the community and strives for coordination in services for juveniles.

Paradigm. II Radical

The radical orientation places primary emphasis on the economic and political structure of the society. Following Marxist tradition, delinquency is seen as an outgrowth of the achievement and competitive ethos of capitalism. It is also seen as functional to the capitalist interests as attention is diverted from economic injustices. Delinquent behavior might also be seen in this perspective as an expression of the class conflict - a political statement of dissatisfaction with the economic system. Institutional labelling such as racism and sexism fit in this category as these derive from the values of the society. The role of the worker in the radical perspective is in economic and institutional change. This would 
include legislative effort to change society's definition of what is delinquent.

It is our intention to examine whether these categories of our theoretical framework can be observed among workers employed in a variety of delinquency programs. The following Review of the Literature will summarize theories of juvenile delinquency causation and examine current delinquency programs. These theories of causation will be also related to our Paradigm I/Paradigm II categories. 
CHAPTER II

REVIEW OF THE LITERATURE

\section{DELINQUENCY THEORIES AND RESEARCH}

\section{Introduction}

Juvenile delinquency is commonly thought of as a problem. However, there is a lack of agreement on. what juvenile delinquency is, how much of it there is, who is involved, what causes it, and what to do about it. There has been much discussion and theorizing about the causes of juvenile delinquency. These various perspectives will be examined.

To understand delinquency, it is necessary to look not only at the individual's behavior, but also at the social response. Public opinion, legal sanctions, police procedures, and correction systems all influence how delinquency is perceived and handled. Therefore, "Juvenile delinquency consists of acts or infractions which are prohibited in the statutes of the individual states. Juvenile delinquents are youths who commit one or more of these crimes" (Gibbons, $1976)$

Presently, under these statutes, there are two types of 
offenses. The first type is the offenses that are also illegal for adults. According to FBI statistics, in 1975 juveniles were responsible for 21.6 percent of the homicides, 17.6 percent of the forcible rapes, 34.3 percent of the robberies, 17.6 percent of the assaults, 52.6 percent of burglaries, 45.1 percent of the larcenies, and 54.5 percent of motor vehicle thefts (U.S. Dept. of Justice, 1976). The second type of offenses is usually referred to as status offenses: those offenses that would not be criminal if committed by an adult. Examples of status offenses include running away, truancy, drinking alcohol, breaking curfew, or being beyond parental control. Status offenses have accounted for half of the referrals for girls to juvenile courts and one-fifth of the referrals for boys (Perlman, 1970). In 1975, 28 percent of the referrals to the Juvenile Justice Department of Multnomah County were for status offenses (City Club of Portland, 1976). Status offenses are an example of labelling - a Paradigm II Liberal perspective.

Delinquent behavior may be sporadic, or it can evolve into more serious, repetitive behaviors. Delinquent behavior of both types may come to the repeated attention of police and court officials. The official delinquency statistics reflect the identification of and response to delinquent behavior by the police and courts. There is much delinquency that is not noticed in the official reports. Studies in the past have tended to ignore the vast amount of delinquent 
behavior which never becomes official delinquency (William and Gold, 1972).

There is a multitude of estimates on how many youths are involved in unrecorded delinquent acts. In one study, respondents overall reported a large number of undetected violations (Empy and Erickson, 1965). Short and Nye (1958) and Williams and Gold (1972) have conducted several studies on unobserved delinquency. They have shown that a majority of youth commit at least one delinquent act. Gibbons (1976) feels that those who come in contact with police are usually involved in more serious, repetitive offenses. However, there may be some selective observing on the part of the police, who pay more attention to high crime and low-income areas. Middle and upper class communities may have more acts of delinquency that are not observed because of less police coverage (Gibbons, 1976). Some studies have reported that middle-class respondents commit the most serious and destructive kinds of acts, while lower class respondents were involved in smoking, skipping school, fighting, and narcotics. The number of violations did not differ very much from one socioeconomic class to another (Empy, 1965).

Other researchers believe there is a relationship between social class and juvenile delinquency, and have conducted studies that are designed to explain why almost all official statistics report delinquent incidents involving mostly lower class juveniles. These 
researchers give support to a Paradigm II Radical concept of institutional labeling as lower class delinquency is reported more, not actually more prevalent. Gibbons (1976) uses the following diagram (Figure 1) to depect the nature of delinquency.

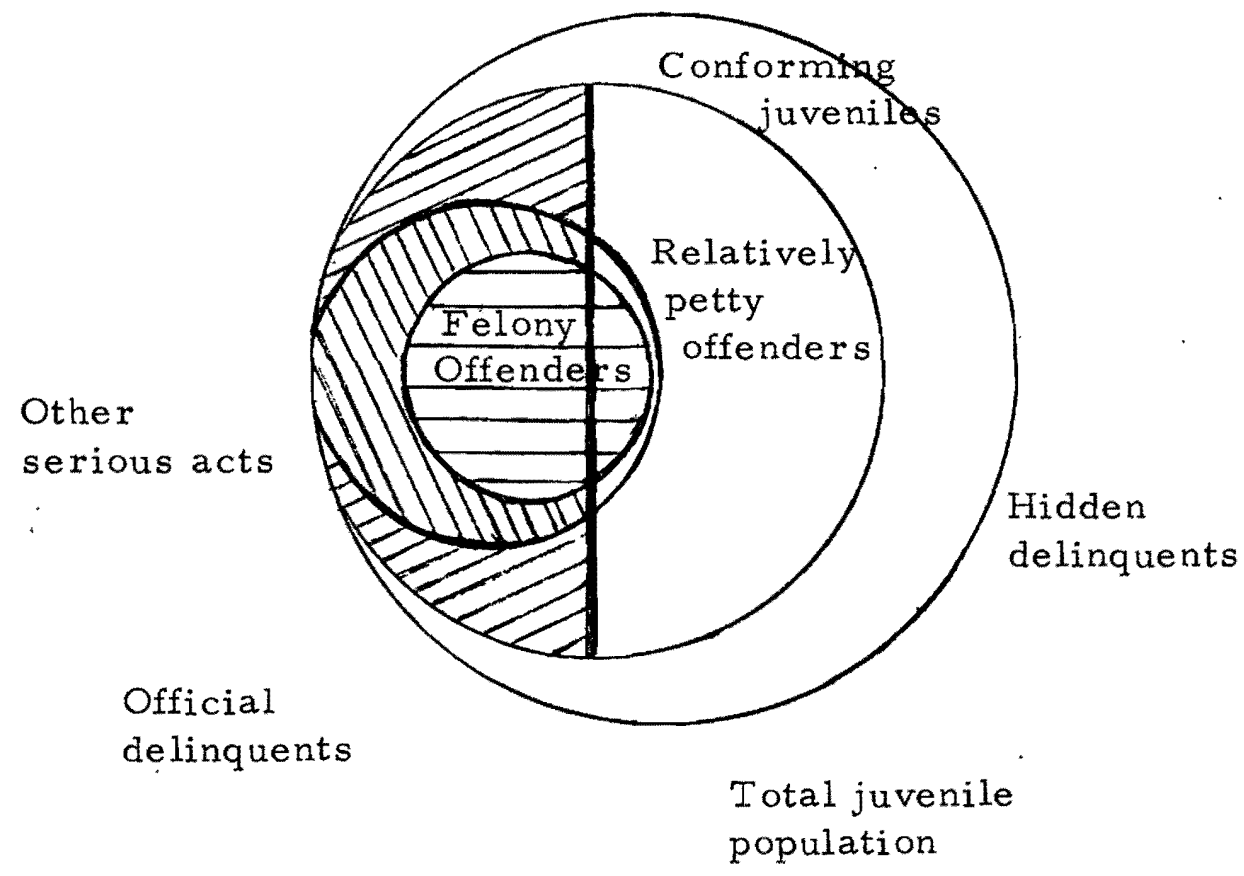

Figure 1. Nature of Delinquency

\section{Disposition of Youth}

After juveniles come in contact with the police, some are dismissed with no further action, usually with just a warning. FBI statistics for 1975 indicate that 41.6 percent of apprehended juveniles were handled this way (U.S. Dept. of Justice, 1975). There has been some evidence that the lower class youth has the lowest rate of case 
dismissals $(40 \%)$ and the highest rate of severe sanctions $(32 \%)$

(Sieverdes, 1974).

There have been numerous studies on police dispositions.

Their results are not conclusive. In most cases, the deciding factor in how the juvenile was handled was the seriousness of the offense. The juvenile's attitude was also related in the sense that more deferential youths tended to receive a warning. In some cases, racial and economic factors influenced the disposition. Consequently, whites and higher income groups received only warnings, additional support for Paradigm II Radical causation theory. Sieverdes' research also supports this perspective. Overall, the studies reflect a lack of uniformity among police departments in how they handle delinquent acts (Gibbons, 1976).

Causes of Delinquency

There are three main approaches to causation theories. One is biological, which stresses the presence of some innate or internal problem within the individual to cause him/her to act in a delinquent manner. Eleanor and Sheldon Glueck (1956) discuss the relationship of body types to delinquency. They reported a more muscular body type was more predominant among institutionalized delinquents. These biological theories are a clear example of a Paradigm I Conservative perspective. 
Biological theories have not had the influence on public policies that the psychological approach has had with its various concepts. The delinquent can be viewed as a "psychopathic personality, "and both biological and psychological explanations are used (Schur, 1973). Another, emphasizes developmental deficiency which results in an inadequate ego (Grossbard, 1962). This problem can be caused by environmental factors such as parents who give their child a poor self-image or by a basic disturbance in one's personality structure. The psychological theories fall in our Paradigm I Liberal category.

One of the difficulties in testing the se theories lies in operationalizing these concepts as the data found can be interpreted in different ways. For example, one of the main studies based on the Jesness inventory reports, states that the institutionalized delinquents were more hostile, felt more isolated, and were less mature than non-institutionalized youths. However, these feelings could be a result of the institutionalization and involvement in the correction system (Jesness, 1962).

The third approach to looking at delinquency causation emphasizes how societal structures contribute to delinquent behavior. These sociological theories can be divided into broad and middle-range theories. The broad theories look at society as a whole in trying to explain delinquency; middle-range theories deal 
with a specific area of society or kind of delinquency (Gibbons, 1976). Both fit in our Paradigm II.

\section{Broad Range Theories}

Merton's (1970) anomie theory looks at society as a whole.

This theory holds that deviance is a response to the unavailability of socially approved routes to success. This theory has been applied to a more specific middle level by Cloward and Ohlin (1960) to explain gang delinquency. These theories represent Paradigm II Liberal.

Another group of theorists believe social disorganization leads to delinquent behavior. Believed to be contributing factors are a lack of social coordination, a lack of relationship bonds, and value clashes between different groups within our society (Gibbons, 1976). The emphasis is on the disorganization in our present society, a Paradigm II Conservative view.

Furthermore, Sutherland's theory of differential association can be characterized as a broad range theory. He sees delinquency as a learned behavior. "Criminal behavior is learned in interaction with other persons in a process of communication" (Sutherland, 1970). Ball and Logan's study of delinquent girls supports this position (Ball and Logan, 1960). Criticisms of this theory have largely been by those who take a psychological perspective of delinquency causation. They find it does not adequately consider personality traits. 
A final theory which also represents our Paradigm II Conservative, stresses the lack of social control in this culture. Hirschi and Toby are main proponents of the "control theory" of delinquents. Hirschi's study showed delinquent youths as being less attached to parents, schools, peers, and conventional activities and most students as being committed to conventional values existing within the education system. The latter, therefore, have good reason to conform since deviation would jeopardize present and future perceived rewards and status (Hirschi and Toby, 1969).

Middle Range Theories

The more general theories seem logical, though they are difficult to test and apply practically. Lately, more theorists utilize "middle" range theories to explain specific types of delinquency. This latter approach does not view delinquents as a homogenous group, but rather as a diverse group of youth involved in different behaviors.

Beginning with the Chicago school in the early 1900s, there has been much attention on working class and lower class delinquency (Gibbons, 1976). The Chicago school's ecological perspective implied that socioeconomic class was at the root of the observed geographical correlation with delinquency (Kassenbaum, 1974). Shaw and McKay, Kobrin Suttles and Landers have all conducted 
studies that support this perspective. Recently, efforts have been directed towards looking at the interactional effects of environmental variables, the delinquent subculture, opportunity structure, and lower class focal concerns, which moves the focus from PII Conservative to PII Liberal.

Studies have related environmental factors to delinquent behavior. Quinney, Polk and Wollis looked at delinquency rates in three cities. They found that economic deprivation and family instability were major factors in causing delinquency (Quinney, 1964).

The concept of a delinquent subculture has been used to examine gang delinquency. "Subcultures are value patterns and behavioral systems which are shared by individual gangs and these precede and persist beyong the life span of any single group" (Gibbons, 1976). Albert Cohen's book Delinquent Boys published in 1955, stimulated a large amount of research. Cohen's thesis was that delinquent subcultures support behavior which is non-utilitarian, malicious, and negativistic (Cohen, 1955). Lower class youth become involved in the subculture because of shared problems of low self-esteem resulting from being measured by middle-clas standards for which they were not properly socialized (Cohen, 1955). This basic theme appears in the statement, "The same value system impinging upon children differently equipped to meet it, is instrumental in generating both delinquency and respectability, " (Geis; 
1965). Delinquency, therefore, is a gang member's response to his problems with status and self-respect.

The emphasis on psychological causation exemplifies PI, while Cohen's notion of a supportive delinquent subculture exemplifies PII Conservative.

Bordua (1962), as with Cohen, did not see Cloward and Ohlin giving enough weight to family, racial and other variations among lower-class groups. He also observes that "Cloward and Ohlin's delinquents seem suddenly to appear on the scene, sometime in adolescence, to look at the world and to discover, man, there's no opportunity in my structure" (Geis, 1965). Another major criticism of Ohlin and Cloward's theory surrounds the lack of empirical detail. According to Walter Miller, gang delinquency is the product of long-established, patterned traditions of lower-class life such as female-headed households, which causes the adolescent male to have anxieties about his sex role. Gang involvement is a way for one to prove his masculinity. Miller also describes "focal concerns" which are broad themes of lower class life. These include avoiding involvements with police, being "tough," being able to live by one's wits, having excitement, and being autonomous. These themes can be lived through the gang experience, further examples of the PII Conservative perspective (Gibbons, 1976).

Geis (1965) makes a distinction between three types of sub- 
cultures. The conflict subculture stresses manipulation and violence as ways to win status. Thus, one gains respect by instilling fear in others. In the criminalistic subculture, the "big score" is emphasized, and illegal means are used to obtain income. The final "type" is the retreatist subculture, which stresses drug usage. Moreover, Geis sees gang members as being individuals of four distinct subcultures of society: males, adolescents, urban residents, and youths equipped for low-skilled manual work.

Gibbons (1976) has summed up the vast amount of research done on gang behavior. The opportunity structure theory held up best under research, but the theory does not take into account the many intervening variables, such as family patterns. The evidence seems to indicate there are several explanations for gang delinquency such as social status concerns, deprivations of lower-class life, protection from other boys, etc. However, one cannot generalize about all gangs (Gibbons, 1976).

Middle-class delinquency has begun to receive much attention. The predominant theory centers around the concept of a "youth culture" which has shared concepts of values, behaviors and characteristics different than those of the prevailing adult culture. This social pattern can lead youth into delinquent behavior. The culture is based upon a pleasure principle, emphasizing immediate gratification of "hedonistic" needs. There are several viewpoints on 
middle-class delinquency. Cohen, along with Ralph England, attributes it to the lack of functional roles for the adolescent (Vaz, 1967). Cohen (1972) also discusses "the erosion of adult control" over the youth. Another perspective sees middle-class delinquency as a function of the "social marginality of the 'nouvelle bourgeoise" "; people who have recently become middle-class and have the financial resources but not the social graces for adequate social adjustment (Bohlke, 1967). Furthermore, some believe that middle-class youth are just imitating the delinquency of the lower-class youth (Kvaraceus and Miller, 1967). Josph Scott and Edmund Vaz view the behavior as exaggerations of activities encouraged by adults (Vaz, 1967). These also are theories consistent with our PII Conservative category. There is the theory that sees the youth culture as a symptom of a sociocultural crisis that results from established institutions resisting the change brought on by technological advancement. Since youth are less established in the social order, they are often the first to respond to the crisis. They respond in the form of a crisis of identity - the inability to determine the meaning of one's life and accept the adult roles offered by parents and society in general (Flacks, 1971). Finally, Lopez-Rey proposes that the delinquency is a protest against the way adults are shaping the world, a PII Radical notion of delinquency as a political statement (Kittrie, 1971). There is little research to support these theories. One 
study conducted by Nye points out family instability, parental rejection and lack of commitment to church as being correlated to delinquency. Adolescents who came from large families or families that had changed socio-economic class were also more likely to engage in delinquent acts (Nye, 1958). Gerald Pine's study supports the idea of lack of commitment to adult roles as being a factor in middleclass delinquency (Pine, 1955). However, much more research needs to be conducted before any conclusive statement can be made.

\section{Female Delinquency}

Until recently, there has been little attention paid to female delinquency. Most of the studies have centered mainly on male adolescents. Traditionally, only a minority of the court referrals were females, and they appeared to be treated differently.

Various actions taken against female juveniles are harsher than those directed at males in comparable forms of misbehavior ... the juvenile justice system operated in ways that are concerned less about the protection of the rights of youthful females than with the interests and values of other groups. (Gibbons, 1976)

Meda Chesney-Lind states that the authorities are most likely to take action against young women who are suspected of being involved in sexual behavior or in danger of becoming involved in sexual experimentation. Such action is not taken against males (ChesneyLind, 1974). The courts interpret the laws differently for delinquent 
females than for delinquent males. Cohen explains female delinquency essentially according to the subculture concept. He points out that middle-class girls tend to develop certain sexual patterns useful to them in their attempt to move up the social ladder. For the working-class girl, there is no apparent "pay-off" for such intricate sexual behavior. Therefore, the temptations and pressures to participate in sexual activities for pleasure and status reasons is not particularly strong for the working class girl since the re are not any reasons to behave so (Cohen, 1955).

Other theories on female delinquency stress the parent-child relationship and the different treatment of males and females in the home. Often, family conflict occurs when girls are more closely supervised than boys. Delinquent girls are therefore responding to the family tension. This was shown in studies on female runaways who were trying to cope with an intolerable home situation and on those picked up for sexual misbehavior. These girls were seen as trying to obtain affectional relationships outside the home (Gibbons, 1976). A study on lower-class female delinquents showed that most were white and fifteen years old. Also, 80 percent came from broken homes (Ball and Logan, 1960). Ball and Logan believe, too, that the differential association position is of importance here; peer pressure to conform to group expectations plays a large role. Again not enough research has been conducted on female juvenile delinquency 
to make any conclusive explanation. With the present changing of sex roles, changes in female delinquency and society's 'response to it may occur.

Labeling

An increasingly acceptable point of view in understanding delinquency causation is labeling theory. Based upon it and its consequences advocated by Becker, Lemert, Schur, Kitsuse and Erickson, evidence supports the notion that the official response to delinquent behavior may initiate processes that push a youth into further delinquent conduct and make it difficult for him/her to reenter the conventional society (Wheeler and Cotrell, 1966). Thus, society's reaction to deviant acts like delinquency, and the resulting labeling of the individual as a deviant, greatly effects subsequent law violations. Matza (1964) sees labeling theory as looking at the enforcer of the rules rather than the violator. The first "dramatization of evil" occurs with one's first contact with police which then sets in motion a process that will bring the juvenile again and again to official attention.

The process of making the criminal, therefore, is a process of tagging, defining, identifying, emphasizing, segregating, describing, making conscious and self-conscious; it becomes a way of stimulating, suggesting, emphasizing and evoking the very traits that are complained of. The harder parents, police, court, etc., work to reform the evil, the 
greater the evil grows under their hands. (Tannenbaum, 1938)

Schur, too, believes that the juvenile court is a major participant in the labeling process. The juvenile court stigmatizes the individual. Stigmatization is a process which implies that deviants are morally inferior. It is a form of degradation that comes out in the use of jails for detention, the dispositions that deprive children of their freedom, the location of juvenile courts within the regular court system, and the court's close relationship with the police department (Lemert, 1973). Less commitment to school, a proposed stimulus to delinquency, may be caused by negative labeling. One who is thought to be a poor worker, a behavior problem and unmotivated is likely to receive different treatment by one's peers and teachers (Kelly and Pink, 1973). Most labeling theory fits in our P II Liberal category.

In summary, there is no conclusive perspective on the cause of juvenile delinquency. The assumptions and procedures on which studies of delinquency causation depend continue to expose serious methodological weaknesses. Delinquent behaviors take a wide variety of forms with diverse and complex antecedents. Family relationships, socio-economic factors, commitment to and opportunity to fulfill adult roles, low self-esteem, and other concepts may all be considered as factors in causation. 


\section{DELINQUENCY INTERVENTION}

In 1970, about one million youths between the ages of ten and seventeen were referred to this country's courts and an additional three million experienced a police contact that year (Mech, 1975). Proections for 1977 suggest that nearly fifteen million youths and their parents will be referred to juvenile courts (Gemignani, 1972). It is conservatively estimated that it cost one hundred dollars per youth to refer him/her to juvenile court in 1970. The annual price tag is approximately one hundred million dollars (Gemignani, 1972).

In this second part of the literature review, we will discuss. delinquency intervention. Three areas will be covered: 1) Conceptual frameworks of delinquency intervention, 2) types of delinquency intervention programs and evaluative studies, and 3) recent trends in delinquency prevention forms.

\section{Delinquency Intervention Perspectives}

Basically, there are three perspectives in looking at delinquency intervention. The first perspective sees all youth as a target for delinquency prevention programs. Prevention is synonymous with promoting a healthy development for all youth. The target for prevention action is the social setting that gives rise to delinquency (Geis, 1965). Thus, delinquency is seen as a function of 
environmental and institutional weaknesses such as poor family relations and prejudice and discrimination against minority groups. These types of programs would range from P II Liberal to Radical.

The second perspective focuses on potential delinquents or those who seem to be on the road to delinquency. Here the priority is programs that would identify such youth and forestall delinquent acts. Unlike the first perspective, this approach is aimed at a limited clientele. This view stresses direct service intervention with youth, rather than improved environmental and/or institutional conditions (Mech, 1975). The individual is seen as the target for change. The kinds of direct service to be provided depend on the program planners' views of why youth become delinquent and what measures will counteract or avert delinquent tendencies. All individual intervention is consistent with our PI viewpoint.

The third way to look at delinquency intervention focuses on juvenile offenders and emphasizes reducing rates of recidivism and lessening the probability that the individual will commit more serious offenses. This perspective does not emphasize preventing the onset of delinquency. Its programs deal primarily with youth who have already participated in illegal behavior and been brought before the court. Rehabilitation through treatment is stressed. This perspective is the narrowest of the three views on delinquency intervention (Mech, 1975). The different sets of priorities they reflect, 
and thus the differences in programming they imply, make it clear that no one strategy is universally feasible for everyone (Empy, 1970).

\section{TYPES OF INTERVENTION PROGRAMS AND EVALUATIVE STUDIES}

The following will review delinquency intervention programs that have been implemented in the past and that relate to the three frameworks previously discussed. Dr. Edmund Mech, the first director of the Region $\mathrm{X}$, Regional Research Institute at Portland State University, has classified, described and critically analyzed delinquency intervention programs that have been reported by research and demonstration projects. He has divided intervention programs into small-scale and large-scale programs.

\section{Small-Scale Intervention Programs}

Essentially, small-scale programs focus on individuals and small groups such as the school, family and police. Through the programs, attempts are made to change the feelings and attitudes of the individual delinquent. There are several underlying assumptions in these programs. One is that deviancy is the result of intrapsychic malfunctioning which then requires some form of individual the rapy to rectify. This notion is reflected in a statement by Hyman Grossbard, "It is my belief that all delinquents, regardless of thic 
type of disturbance, have certain common psychological processes that operate vertically in their history and horizontally in their functioning" (Grossbard, 1962). He also maintains that delinquents have insufficient ego mechanisms and are characterized by a lessened ability to tolerate frustration, control responses to stimuli, or postpone gratification. Such treatment techniques as psychotherapy, casework, counseling, and guidance with individuals and small groups are advocated.

Mech went further and broke down small-scale intervention programs into seven sub-types: outreach, individual services, group services, work experiences, behavior modification, special. education provisions, and adult models (Mech, 1975). He selected five studies for evaluation.

\section{Outreach}

Outreach implies going out into the community and contacting youth and their families who may be unable or unwilling to come to the social agency. The aims of outreach programs usually include: 1) Providing direct services to youth or referring them to other agencies when necessary, 2) aiding youth in finding socially acceptable life styles, 3) developing community interest in youth, and 4) providing services to families unable to seek help (Mech, 1975). Of the five outreach programs reviewed by Mech, only three reported 
results: Neighborhood Youth Association, Los Angeles; Henry Street Settlement, New York; New York City Youth Board. The first project reported no significant difference and the other two claimed positive results. However, much of the evaluative information was subjective with a general lack of scientific methodology throughout the studies.

Services to Individuals

Individual service programs are the most traditional and most commonly utilized intervention approach. These programs generally assume that the individual suffers from some inner developmental disorder. Program aims usually include 1) to aid youth with problems, and 2) to assist youth with school, leisure time and employment. The five programs selected were the Boy's Club, Los Angeles; Delinquency Control Project; Greater Kansas City Mental Health Foundation; Bethel Neighborhood Services, Inc.; and the Neighborhood Youth Association in Los Angeles. Two of the se programs reported significant positive results, though the evaluative information was subjective. One did not report a significant difference. The remaining two included no evaluation material (Mech, 1975).

\section{Group Services}

A frequent approach to delinquency programming is to provide group services to youth and parents. The group creates an environ- 
ment which enables parents and youth to share their problems with others who have similar concerns. These group services are based on the assumption that parents can learn new ways to deal with their children, and thus their family situations and the behaviors of their children will improve. The program aims associated with group services usually include: 1) To aid parents in resolving youth's problems, 2) to provide casework to disadvantaged families, 3) to strengthen the family unit and aid youth in creating a wholesome milieu, and 4) to involve community agencies in treating a recidivist youth. The programs Mech selected were the Metropolitan Youth Commission in St. Louis; United Neighborhood Houses of New York; Judge Baker Guidance Center, Boston; Special Services for Groups in Los Angeles; and the Traverse Youth Center in Flint, Michigan. Only one reported an evaluation which showed significant positive results, though it was also largely based on impressionistic accounts. The other four programs reported no information on evaluation (Mech, $1975)$.

Work Experience

Work experience programs are based upon the idea that productive work activities will deter delinquent behavior. Program goals generally include: 1) Providing training and guidance, 2) rehabilitating problem youth through a work program, and 3) keeping 
youth in school through a work-study program. Each of the programs reviewed reported a significant positive impact on youth. No evaluation of the methodology was made. The programs Mech selected were the Job Upgrading Project, North Richmond, California; Youth Conservation Corps, Philadelphia; Job Placement and Work Therapy Program, Cincinnati; Carson-Pirie Scott Double EE Program, Chicago; and Boy Builders of Bloomington, Indiana.

\section{Behavior Modification}

The fifth category of small-scale intervention programs is that of behavior modification. Basically, they assume individuals behave as they do because their environment reinforces such behavior. The goals of such programs generally are: 1) To train parents in the techniques of behavior management to enable them to control youth, 2) to improve the use of positive reinforcers in the lives of youth, 3) to modify pre-delinquent youths' behavior in the natural home setting, and 4) to devise and evaluate methods of reducing predelinquent and delinquent behaviors in youth. Of the programs Mech selected in this review, e.g., Oregon Research Institute; Southwest Indian Youth Center, Tuscon; and University of Kansas "Achievement Place;" all claimed significant positive results. Moreover, the methodology used in evaluating these behavior modification programs was scientifically validated with the evaluative information being 
objective (Mech, 1975). The validity of behavior modification techniques has also been demonstrated at the Behavioral Research Project of the Southern Arizona Mental Health Center (Thorne, Thorpe, and Wetzel, 1967).

\section{$\underline{\text { Special Education }}$}

The area of special educational programs stresses efforts conducted in school settings to prevent delinquency. Program aims include: 1) Presenting employers, teachers, policemen, and parents as ordinary people with likes and dislikes, and problems; 2) acquainting parents with various school projects and academic objectives and enlisting their participation; and 3) providing tutorial services. The Metropolitan Youth Commission of St. Louis and the Columbus, Ohio Project have utilized this approach (Mech, 1975). No studies of this approach were reviewed.

\section{Adult Model}

The last category of small-scale intervention programs implies using adults as models or examples for youth. Program. aims include: 1) Keeping youth in school and then graduate; 2) preventing youth from commiting further law violations; and 3) giving fatherless youth an opportunity to see adults as husband, wife, parent, and citizen and to identify with them as total people. The Clear Lake Project in Houston; Friendly. House, D. C. ; Denver 
Boys, Inc.; and Glenville High, Philadelphia all implemented this kind of intervention approach (Mech, 1975). Again, Mech did not review any evaluations of this approach.

In summarizing the small-scale intervention programs, very little conclusive evaluative information is available to validate the effectiveness of such programs. However, those programs implementing the behavior modification approach were the most successful in validating their effectiveness because their research methodology was the most scientific. There is a definite need for more effective research in evaluating delinquency intervention programs.

Large-Scale Intervention Programs.

Large-scale programs comprise the other category of delinquency intervention programs. They denote interventions that derive from analyses of the social conditions that help to create delinquency. Thus, they represent attempts to deal with and change environmental conditions. Likewise, the programs are generally not concerned with the youth him/herself (Martin, 1961). Mech describes three types of large-scale interventions: Area improvement efforts, coordination of services', and recreational approaches (Mech, 1975). These organizational interventions mostly represent a P II Liberal perspective. 
Area Improvement

Community involvement is inherent in the area improvement programs. They aim to: 1) Develop effective methods of inducing local residents to commit themselves to preventing delinquency, 2) improve services to the clients in public bureaucracies, 3) develop self-organization and encourage disadvantaged residents to participate in public decisions influencing their lives, and 4) develop local communities so that residents could become the chief force for changing the character of their neighborhoods (Mech, 1975). Some programs that have utilized this approach are: The Chicago Area Project; Mobilization for Youth Project, Syracuse; Crusade for Opportunity and United Planning Organization; Houston Action for Youth; much "hard" data was collected to support the evaluations of the above programs. However, many discussions of these programs showed that "natural" citizen involvement was created at a local level to support delinquency prevention efforts (Mech, 1975).

\section{Coordination of Service}

Coordination of community services also acknowledges that the primary concern should not be the individual's deficiencies. This approach recognizes the difficulties facing established community services which lack the coordination necessary to have an effective impact. Program goals include: 1) Coordinating serviccs 
offered to youth in communities, 2) locating individuals in need and secure services for them, and 3) enhancing cooperation between existing agencies in a community that provides social services. Examples of coordination projects are the New York City Youth Board; Minneapolis South Central Youth Project; and the Passaic, New Jersey Children's Bureau. New Jersey is the only state that defines youth problems primarily as educational to be dealt with by the school system. It essentially achieves the goal of putting youth problems into a non-legal context (Lemert, 1971). Unfortunately, there were no formal evaluations made of the effectiveness of these programs although ties between community agencies were reported as being strengthened (Mech, 1975). The best data available for evaluation was from the New York City Youth Board where there was a mixture of praise and fault-finding (Lemert, 1971).

\section{RECENT TRENDS IN DELINQUENCY PREVENTION REFORM}

A definition of prevention is a necessary starting point. Basically, prevention has traditionally implied stopping delinquency before it occurs. Thus, delinquency prevention programs are concerned with planning and carrying out some kind of measures prior to the delinquent acts.

However, many researchers have discussed the overall ineffectiveness of past prevention programs. Logan concludes: 
We find that as far as the survey and review has been able to determine, there is not yet one single study of correctional or preventative effectiveness that will satisfy the most minimal standard of scientific design. (Logan, 1972).

He states that some of the methodological weaknesses are that the programs or techniques are not adequately defined, the techniques are generally not capable of being repeated, many lack a control group, assignment of cases to the control group are not random, and finally, a follow-up in the community does not occur.

In response to public criticism and deficiencies in the delinquency prevention programs, The President's Commission on Law Enforcement and Administration of Justice established a Task Force on Juvenile Delinquency in the mid-1960s. They concluded:

... the great hopes originally held for the juvenile court have not been fulfilled. It has not succeeded in rehabilitating delinquent youth, in reducing or even stemming the tide of juvenile criminality, or in bringing justice and compassion to the child offender. (President's Commission on Law Enforcement, 1967).

Consequently, it is necessary to consider redefining delinquency prevention. Empy supports this by contending that "prevention may be defined as the process by which young people acquire a legitimate identity, a stake in conformity, and a respect for the juvenile justice system" (Pink and White, 1973). This premise is at the root of three new concepts in delinquency prevention: diversion, 
absorption, and normalization. These concepts a re based on the recognition that individuals are often controlled by institutions over which they, have no influence (e.g., government, education, courts). Diversion is the process of channeling youth participating in status offenses out of the juvenile justice system. The need to develop non-legal alternatives for youth has been emphasized by the President's Commission. The Commission discouraged the practice of direct referral to court of "minor" delinquents or of "non-criminal law-violating" juveniles. The Report formulated a goal of handling youth outside the juvenile justice system and that non-judiciary alternatives be created by "community efforts" and that services "be local" (President's Commission on Law Enforcement, 1967). They recommended the formation of a Youth Service Bureau with a broad range of services and some mandatory functions. It would provide and coordinate programs and services for delinquents and pre-delinquents. Advantages in the use of such diversionary community agencies are that they would avoid the stigma of being handled by an official agency and raise the community's awareness of the need for recreational, employment and other youth development services. Local resident involvement could also bring greater appreciation of the complexity of delinquents' problems (President's Commission on Law Enformcement, 1967). There have been as many criticisms as praise for the Youth Service Bureaus concepts. 
The National Study of Youth Service Bureaus in 1972 noted that it is impossible to prove that a significant number of youths have been diverted from the juvenile system by Youth Service Center programs. A conflict also exists between those who view the Youth Service Bureau as a direct service agency with individual case loads and those who feel it should develop new resources to fill gaps and to respond to unmet needs (Klapmuts, 1974).

Lemert feels that diversion can be a viable process, and that it could be organized within existing police, school, welfare and community organizations (Lemert, 1971). Such programs exist in several California communities. Diversion of youth from the juvenile justice system would lower the possibility of individuals becoming involved in secondary deviance. The least contact with stigmatizing institutions, the better. It is estimated that in 1977 , 1.5 billion dollars could be saved in official court costs by adopting a diversionary policy (Gemignani, 1972). Some feel that the effectiveness of diversion has not actually been tested. Studies have been limited to a follow-up of recidivism among youths (Klapmuts, 1974).

Absorption implies the process of various institutions not reporting delinquent acts to the police but handling them themselves. This notion was first developed by Carter, who defined it as:

The attempt of parents, schools, neighborhoods, indeed communities, to address the problem of delinquent and deviant youth by minimizing 
referral to official state or county agencies designated to handle such youth, or if there has been a referral to one of these agencies, the attempt to remove the offender from the official process by offering a solution, a technique, or a method of dealing with the offender outisde the usual agency channel. (Mech, 1975).

The Southeast Youth Service Center, in Portland, Oregon has implemented this concept. A large neighborhood business refers shoplifters directly to the Center without first going through the police and court systems. Diversion and Absorption programs represent a Paradigm II Liberal perspective.

Normalization is treating behavior presently seen as deviant as if it were not. It focuses on youth not being routinely processed through the justice system. Consequently, status offenses will no longer be classification. Schur (1973) terms this "do-nothing" approach "radical non-intervention." He bases his viewpoint upon the research of "hidden" delinquency, "contol" theories, and labeling studies of the juvenile justice system. It is thought that many who participate in minor delinquent acts may eventually grow out of it. Therefore, this approach stresses the need to reassess youth problems, take youth more seriously, and narrow the jurisdiction of the juvenile court so behavior not illegal for adults is eliminated. Criticisms of this non-intervention approach have been that if the offender is ignored, he may continue the delinquent behavior for the 
same reason he began, and that the present process of official police handling may have a deterrent effect on youth (Wheeler and Cottrell, 1966). Normalization, which requires institutional change, fits in our Paradigm II Radical category.

In conclusion, this review of the literature on delinquency prevention programs demonstrates their complexity. The first section of this review summarized delinquency itself, police response to it, and the wide variety of causation theories. One most important is sue that has been continuously emphasized throughout this review is how difficult it has been for the many researchers in the field to agree on a conceptual model of delinquency. This lack of agreement carries over to delinquency prevention programs. Another theme that has been consistently highlighted throughout the literature is the necessity to develop research methodologies which provide more accurate evaluative information about programs that are devised. It is also important that people in this field learn from the mistakes of previous approaches, and develop new strategies which will not replicate these mistakes. 


\section{CHAPTER III}

\section{RESEARCH DESIGN AND METHODOLOGY}

This research follows a previous study by Longres and Wyers (1976) on the attitudes of administrators towards juvenile delinquency causation and programs. The present research is focused on the attitudes of line workers in juvenile delinquency programs. It will also test the validity of an instrument designed to reflect the theoretical paradigms and categories previously discussed.

Our intention is first to determine whether the theoretical paradigms can be observed in our sample. This will be determined through a factor analysis of the responses to a questionnaire constructed around the various dimensions of Paradigm I and Paradigm II as presented in Chapter I. The fartor analysis is a tesi of multiplo: correlations which will determine which questions are significantly related to each other by the responses of individuals in our sample.

Secondly, we will report the mean responses to significant questions and make some comparisons to the previous study of administrators. Finally, the questionnaire used is very long and we were not altogether sure if we had operationalized the dimensions of Paradigm I and II accurately. Thus, to some extent, the data 
presented here is a pre-test. Based on our analysis, we intend to design a shorter, more useful questionnaire. This will accurately reflect all the theoretical categories and could be more easily administered to a larger sample for comparison of sub-groups; perhaps testing differences in attitudes between those who work in different agencies or between those with different levels of education.

The Collection of the Data

Our sample was a representative cross-section of workers involved in juvenile delinquency programs by utilizing a balanced variety of agencies in our survey. Some agencies whose administrators were surveyed by Longres and Wyers (1976) were used in the study. Additionally, an attempt was made to represent in the sample workers in the state child welfare agency (Children's Services Division), juvenile court counselors, child care workers in residential programs and workers in "alternative" programs. The sample is not a random sample.

Many agencies were contacted and several granted the time for their staff to respond to our questionnaire. We finally surveyed a sample of 101 workers in the selected agencies. The agencies whose workers participated in this survey were: Washington County Children's Services Division; Washington County Juvenile Department; Marion County Children's Services Division; Marion County 
Juvenile Department; Columbia County Children's Services Division; The Christie School; Cordero Youth Care Center; Contact Center in Portland, Oregon: Southeast Youth Service Center, Southwest Youth Service Center, and North Portland Youth Service Center.

The researchers tried to schedule the administration of the questionnaire during the agencies' regular staff meetings to economize time. However, it became increasingly difficult to maintain this procedure. Administrators in smaller agencies were unable to allocate that large a block of time for all staff. In these instances, the questionnaires were left with the administrators to give to their staff. Although the number of questionnaires administered in this manner was small, the loss of control in the administrations of these questionnaires could affect the reliability of the responses. When the questionnaires were returned by the administrators, most stated that their workers answered them on an individual basis and did not consult others about the questionnaire.

In the largest part of the sample the instrument was administered in a group. A brief introduction of the researcher and a general overview of the research was given with an emphasis on the fact the research was an attitude survey. It was stated that the instrument was self-explanatory, but if questions arose, they would be answered. The average time for completing the questionnaire was 30-35 minutes, though the range was from 20-60 minutes. 


\section{The Instrument}

The data was collected by means of a questionnaire administered to line workers in juvenile delinquency programs. The questionnaire was developed to measure the theoretical orientations of these workers. The questionnaire consisted of a face sheet requesting personal background and three sections of statements about juvenile delinquency: causes, programs, and the role of the worker. The researchers indicated the questionnaire was intended to measure how much adjudicated delinquent behavior was explained by the statements. Each of the sections was prefaced with an explanatory paragraph regarding the ensuing questions. All sections followed the same format. A statement was presented and the respondent answered on a seven-point Likert scale, ranging from strongly agree to strongly disagree. Each statement on the questionnaire represents a category in the previously discussed theoretical framework (Paradigm I, Conservative, Liberal, Radical; and Paradigm II, Conservative, Liberal, Radical). The following Table indicated the arrangement of the questionnaire. 
TABLE I

THEORETICAL ORIENTATION

\begin{tabular}{|c|c|c|c|c|c|c|}
\hline & \multicolumn{3}{|c|}{ Paradigm I } & \multicolumn{3}{|c|}{ Paradigm II } \\
\hline & \multicolumn{3}{|c|}{$\begin{array}{c}\text { Personal Problem } \\
\text { Orientation }\end{array}$} & \multicolumn{3}{|c|}{$\begin{array}{c}\text { Structural Problem } \\
\text { Orientation }\end{array}$} \\
\hline & conservative & libe ral & radical & conservative & liberal & radical \\
\hline \multicolumn{7}{|l|}{ Cause } \\
\hline \multicolumn{7}{|l|}{ Program } \\
\hline Worker Role & & & & & & \\
\hline
\end{tabular}

The questionnaire was constructed so that the six categories were evenly distributed in the three sections of the instrument. Statements were designed to reflect these categories and examples follow.

On The Causes of Delinquency

A Paradigm I Conservative emphasizes biological or genetic factors such as lower innate intelligence. An example of this category would be: "Biological factors such as brain abnormalities and chromosomal peculiarities play an important part in causing delinquency."

A Paradigm I Liberal sees factors such as poor self-image, 
psychological and personality deficiencies as the causative factors of delinquency. An example of the category would be: "Psychological problems of youth such as a poor self-image and difficulties with selfidentity are important in causing delinquency. "

The Paradigm I Radical category is less developed than the others, especially in the area of causation. Example of this category is: "Juvenile delinquency reflects alienated youth striking back at an unjust system."

The Paradigm II Conservative argument places emphasis on the institutional arrangement or the past which are assumed to have less delinquency than the institutional arrangement of the present. An example would be: "A youth's immediate environment, especially poor family relationships and negative peer influences, are important in causing delinquent behavior."

The Paradigm II Liberal views the cause of delinquency as the breakdown in important systems which affect youth. This is a reformist point of view which focuses on disorganizational arrangements, e.g., run-down neighborhoods, poor housing, deviant subcultural values. An example would be: "Delinquency is caused by a breakdown in community relations including dysfunctional schools and neighborhoods."

The Paradigm II Radical argues that the causative factors are the result of inequitable economic and social structural arrangements. 
An example would be: "To the extent that capitalism can not function without a poverty or near poverty class, it contributes importantly to the creation of delinquency."

Program and Policy Considerations

The Paradigm I Conservative emphasized programs that are authoritarian and structured. Programs generally aim to punish, control, or keep youths busy. An example would be: "Although we should try to help all youth, many are so set in their ways that little can be done to change them."

The Paradigm I Liberal programs stress counseling and therapy. Individuals are seen as changeable through the many modalities of treatment available. An example would be: "Programs for youth should be designed to improve their inter-personal skills for communicating and getting along with others."

The Paradigm I Radical argues that the deficiency of delinquents is a lack of consciousness about the social structures that oppress them. Radical programs would de-emphasize counseling but not do away with it. An example would be: "Programs for youth should assure that the youth they serve have policy imput."

The Paradigm II Conservative would be similar to the personal problem orientation.: Aside from the concern with reactionary change, it would see youth as not possessing the virtues and values of the past 
and would attempt to instill them. An example would be: "The traditional values of family life should be supported by social service programs."

The Paradigm II Liberal programs would aim to change organizations and communities. Programs would try to involve the community in meeting its own needs and improving the conditions of the community. An example would be: "Programs should be designed to encourage the business community to increase employment opportunities for youth."

The Paradigm II Radical programs would function to change societal and institutional structures that affect the youth. An example would be: "Delinquency programs should aim to educate the public about the societal conditions negating the ability of youth to reach their full potential."

\section{On The Role of the Worker}

The Paradigm I Conservative worker is conservative, to be "tough on clients," and teach responsibility. An example would be: "Those who make delinquents 'toe the line' and keep a watchful eye on their behavior get better results than those who are lenient."

The Paradigm I Liberal worker is seen as a therapist, teacher, or surrogate parent. They would be supportive and sensitive to the psychological and interpersonal needs of the youth. An example 
would be: "The principal efforts of youth workers should be to help delinquents gain psychological, growth-producing insights into the causes of their misconduct."

The Paradigm I Radical worker would concentrate their activities oriented towards raising the consciousness of their clients towards their legal rights and the need for a change in society. An example would be: "Workers should help offenders to understand that their misconduct is not the result of neurosis and bad mental health, but rather a function of blocked opportunity. "

The Paradigm II Conservative worker is seen as working with the institutions of the family, school, and sub-cultural groups to develop a more satisfactory adjustment for the individual. An example would be: "Workers should stress the traditional values of family solidarity and responsibility since much delinquent behavior is a function of the breakdown of these values."

The Paradigm II Liberal worker would involve himself in the community working with gangs, parent groups, school personnel and others. An example would be: "Advocacy techniques should be used extensively in order to make organizations, such as schools, social. services, and correctional facilities more receptive to the needs of youth."

The Paradigm II Radical worker would be involved in the political process to change the system and to provide for more 
economic opportunity and normalization of juvenile behavior now labeled delinquent. An example would be: "Any worker should feel free to organize other workers around the issue of understanding the rights of offenders and be prepared to advocate the fulfillment of those rights."

The Sample

The sample consisted of 101 juvenile delinquency workers. These workers represented a variety of agencies including juvenile courts, the state child welfare agency, residential treatment centers, alternative programs and youth diversion centers.

Of the sample, over one-third worked for Children's Services Division, one-quarter for Juvenile courts, one-quarter in diversion programs and one-tenth in residential treatment programs. The mean age of the respondents was 30 , with a range from 19-62 years. One-half of the respondents had a bachelor's degree and one-third a master's level degree. The rest had a high school education with 8 percent of the sample reporting they had not completed high school. Most of the workers reported medium to high level of satisfaction with their jobs. Only 8 percent indicated a low level of job satisfaction. Over two-thirds described themselves as liberal while one-quarter saw themselves as conservative. Only 6 percent of the sample reported their socio-political orientation was radical. 


\section{TABLE II}

A. SELECTED CHARACTERISTICS OF THE SAMPLE:

SEX, AGE, SOCIO-ECONOMIC STATUS

$$
N=100
$$

\begin{tabular}{l|c|c|c|c}
\hline \multicolumn{1}{c|}{ Sex } & $\%$ & No. & \multicolumn{2}{c}{ Age } \\
\hline Male & .43 & 43 & Range & $19-62$ \\
\hline Female & .52 & 52 & Mean & 29.8 \\
\hline No Response & .05 & 5 & & \\
\hline \hline
\end{tabular}

\begin{tabular}{l|c|c|c|c|c}
\hline \multicolumn{2}{c|}{ Father's Occupation } & \multicolumn{4}{c}{ Father's Education } \\
\hline Category & $\%$ & No. & \multicolumn{2}{c}{ Category } & $\%$ \\
\hline Unskilled & .18 & 18 & Less than High School & .29 & 29 \\
\hline Skilled & .20 & 20 & High School & .38 & 38 \\
\hline Professional & .26 & 26 & Baccalaureate & .09 & 9 \\
\hline Business & .25 & 25 & Advanced Degree & .14 & 14 \\
\hline No Response & .11 & 11 & No Response & .10 & 10 \\
\hline
\end{tabular}


B. SELECTED CHARACTERISTICS OF THE SAMPLE:

GEOGRAPHICAL BACKGROUND

$N=100$

\begin{tabular}{l|c|c|c|c|c}
\hline \multicolumn{2}{l|}{ Area Childhood Spent In } & \multicolumn{2}{|c}{ Size Community Childhood Spent In } \\
\hline Category & $\%$ & No. & \multicolumn{2}{|c|}{ Category } & \multicolumn{2}{c}{$\%$} \\
\hline West & .78 & 78 & Less than 15,000 & .38 & 38 \\
\hline East & .08 & 8 & $15,000-50,000$ & .14 & 14 \\
\hline South & .06 & 6 & $50-100,000$ & .14 & 14 \\
\hline Midwest & .07 & 7 & $100-500,000$ & .22 & 22 \\
\hline No Response & .01 & 1 & Over 500,000 & .11 & 11 \\
\hline \hline
\end{tabular}

Where Degree Was Obtained

\begin{tabular}{l|l|l|l}
\hline & \multicolumn{3}{c}{$\%$} \\
\hline Category & .75 & 75 & \\
\hline West & .06 & 6 & \\
\hline East & .08 & 8 & \\
\hline South & .11 & 11 & \\
\hline
\end{tabular}


C. SELECTED CHARACTERISTICS OF THE SAMPLE:

JOB SATISFACTION, CASELOAD SIZE,

TYPE OF AGENCY

$$
N=100
$$

\begin{tabular}{l|c|c|c|c|c}
\hline \multicolumn{2}{l|}{ Level of Satisfaction with Job } & \multicolumn{2}{|c}{ No. of Clients on Caseload } \\
\hline Category & $\%$ & No & \multicolumn{1}{c|}{ Category } & .44 & 44 \\
\hline High & .41 & 41 & $0-15$ & .24 & 24 \\
\hline Medium & .49 & 49 & $15-30$ & .13 & 13 \\
\hline Low & .08 & 8 & $30-45$ & .15 & 15 \\
\hline NoResponse & .02 & 2 & Over 45 & .04 & 4 \\
\hline
\end{tabular}

Type of Agency

\begin{tabular}{c|c|c|c} 
Agency & $\%$ & \multicolumn{2}{c}{ No. } \\
\hline Children's Services Division & .38 & 38 & \\
\hline Juvenile Court & .23 & 23 & \\
\hline Residential Centers & .10 & 10 & \\
\hline "Alternative" Programs & .27 & 27 & \\
\hline Other & .02 & 2 & \\
\hline
\end{tabular}



D. PHILOSOPHICAL PERSPECTIVE
$N=100$

\begin{tabular}{c|c|c|c}
\hline \hline Category & \multicolumn{2}{c}{$\%$} & \multicolumn{2}{c}{ No. } \\
\hline Conservative & .22 & 22 & \\
\hline Liberal & .67 & 67 & \\
\hline Radical & .06 & 6 & \\
\hline No Response & .05 & 5 & \\
\hline
\end{tabular}

Sample of question in which type is based on:

Conservative - The breakdown of traditional family and social values is an important reason for the rise in delinquency.

Liberal - A poorly formed super-ego is a frequent cause of delinquency.

Radical - The causes of delinquency are ultimately to be found in the competitive norms and values of our economic institutions.

\section{Limitations of the Study}

A major limitation of this study was that the sample was not random. Consequently, its results cannot be applied to line workers in general.

There were some limitations inherent in the questionnaire. It was too lengthy, and many questions were repetitive and ambiguous. The arrangement of the questions could have been improved also.

The study's degree of subjectiveness was also a limitation. The questions were categorized according to which theoretical con- 
structs they corresponded. In many instances, there was only a slight distinction between the radical and liberal perspective.

Finally, the field of study itself, was limited. There has previously been little research on the theoretical constructs themselves and on line workers ${ }^{\prime}$ attitudes in general. 
CHAPTER IV

\section{DATA ANALYSIS}

\section{INTRODUCTION TO FACTOR ANALYYSIS}

The research instrument was a questionnaire with items designed to reflect our hypothesized categories. As mentioned in the Methodology section, the questionnaire was developed around the Warren concepts of Paradigm I, personal deficiency perspective, and Paradigm II, dysfunctional social structure perspective. We further refined these concepts to include the categories of Conservative, Liberal, and Radical within each perspective. The questionnaire was separated into three content areas: causes of delinquency, programs to prevent delinquency, and what the role of the worker should be. The questionnaire contained one hundred items.

A factor analysis was applied to the data collected. This statistical technique is appropriate for our major purpose; to determine whether the theoretical categories were perceived as real categories among the workers sampled. The analysis was expected to be helpful in the further refinement of the questionnaire.

The factors were extracted by the principle components 
method and varimax orthogonal rotation was performed. We expected six factors to be extracted to fulfill our hypothesized framework of Paradigm I, Conservative, Liberal, Radical; and Paradigm II, Conservative, Liberal, Radical.

All loadings greater than .5 were considered to belong to a particular factor. All of the attitude statements proved to load highly on only one factor, except for one item that loaded on two factors. Thus, the categories uncovered are distinct, largely independent of each other.

Although six factors were extracted, they did not completely conform to our predicted categories. It seems that the respondents did not isolate their constructs as we had originally thought.

The six factors extracted will now be discussed in relation to our theoretical categories.

\section{EXPLANATION OF FACTORS}

\section{Factors Relating to the Causes}

Factor 1: Dysfunctional Social System. The items in this factor place primary emphasis on the economic and social structure of society as the causes of social problems like delinquency. The items suggest that the institutions of society, e.g., the economic and political systems of capitalism, are essentially causes of 
delinquency. Items such as the "competitive norms and values of the economic system leads to delinquency" and "capitalism cannot function without a poverty class" are examples of the Paradigm II Radical category.

TABLE III

DYSFUNCTIONAL SOCIAL STRUCTURE

\begin{tabular}{|c|c|c|}
\hline Item & $\begin{array}{r}\text { Factor } \\
\text { Loading } \\
\end{array}$ & $\begin{array}{c}\text { Hypothetical } \\
\text { Category }\end{array}$ \\
\hline Society provides few meaningful roles... & .65504 & I I R \\
\hline Impersonality of schools foster delinquency & .64622 & II R \\
\hline Lack of job opportunities............ & .75234 & IIL \\
\hline \multicolumn{3}{|l|}{$\begin{array}{c}\text { Police and justice systems create delin- } \\
\text { quents instead of preventing }\end{array}$} \\
\hline delinquency $\ldots \ldots \ldots \ldots \ldots \ldots$ & .67010 & II R \\
\hline \multicolumn{3}{|l|}{ Competitive norms and values of economic } \\
\hline system.................. & .70303 & I I R \\
\hline \multicolumn{3}{|l|}{$\begin{array}{l}\text { Until the social system provides employ- } \\
\text { ment, we can expect delinquency... }\end{array}$} \\
\hline \multicolumn{3}{|l|}{$\begin{array}{l}\text { Capitalism cannot function without a } \\
\text { poverty class that contributes }\end{array}$} \\
\hline to delinquency $\ldots \ldots \ldots \ldots \ldots$ & .67145 & II R \\
\hline
\end{tabular}

The factor analysis indicates that the sample's responses matched highly the items of the dysfunctional social structure category. However, other items that had been designed Paradigm II 
Liberal were also correlated in this factor. It seems that the sample did not make the distinction between the Radical and Liberal categories within Paradigm II and as operationalized here, although all items did match the structural dysfunction orientation.

Factor 2: Return to Old Values. Items in this factor represent a clear example of Paradigm II Conservative. The items making up the factor emphasize that changes in "old values" of the family institution lead to delinquent behavior. A lack of social control is also emphasized in the items. The items implicitly suggest that return to the traditional value system will help eliminate delinquency.

TABLE IV

RETURN TO OLD VALUES

\begin{tabular}{llc}
\hline Item & $\begin{array}{l}\text { Factor } \\
\text { Loading }\end{array}$ & $\begin{array}{c}\text { Hypothetical } \\
\text { Category }\end{array}$ \\
\hline
\end{tabular}

Youth with free time are more likely to contribute to delinquent behavior than those kept occupied ...... $\quad .67017$ IIC

Lack of firm parental discipline is a factor ................ . 56805 IIC

A morally permissive society sets the stage for delinquency ....... .50001 IIC

Peer group pressure frequently causes delinquent behavior ......... .63003 IIC 
The analysis indicates a clean grouping of the statements which we designated to represent the "return to old values" category. The sample tended to respond to the built-in category in an exclusive manner. There was no cros-over in categories in this factor. The respondents answered in a like fashion to the items in this factor.

Factor 3: Dysfunctional Families. The items making up this factor emphasize that causes of delinquency are to be found within one's immediate social environment, especially the family. The deficiencies within the family could be from a poor self-image or identity, or the result of an unstable family environment or inadequate family socialization.

Of the seven items in this factor, four relate to the influence of ysfunctional family environments in causing delinquency. This grouping indicates a high correlation of statements that we formulated to represent the Paradigm I Liberal category. However, one item that we categorized as Paradigm II Conservative, correlated highly with these other items. The item stresses "negative peer influences." However, it could be regarded as falling into our definition of "immediate social environment." Another item that we categorized as Paradigm II Liberal was included in this factor. The item focused on "breakdown in community relations." Evidently, the respondents also felt this item fit into the "social 
TABLE V

DYSFUNCTIONAL FAMILIES

\begin{tabular}{|c|c|c|}
\hline Item & $\begin{array}{l}\text { Factor } \\
\text { Loading }\end{array}$ & $\begin{array}{l}\text { Hypothetical } \\
\text { Category }\end{array}$ \\
\hline $\begin{array}{l}\text { Delinquency is caused by a breakdown } \\
\text { in community relations } \ldots . . . .\end{array}$ & .58470 & IIL \\
\hline $\begin{array}{l}\text { A youth's immediate environment } \\
\text { especially poor family relation- } \\
\text { ships and negative peer influences.. }\end{array}$ & .67618 & I I C \\
\hline $\begin{array}{l}\text { Psychological problems as poor self- } \\
\text { image and self-identity .......... }\end{array}$ & .52691 & IL \\
\hline $\begin{array}{l}\text { Unstable dysfunctional family environ- } \\
\qquad \text { ments } \ldots \ldots \ldots \ldots \ldots \ldots \ldots\end{array}$ & .71615 & IL \\
\hline Lack of good parenting skills ......... & .60495 & IL \\
\hline 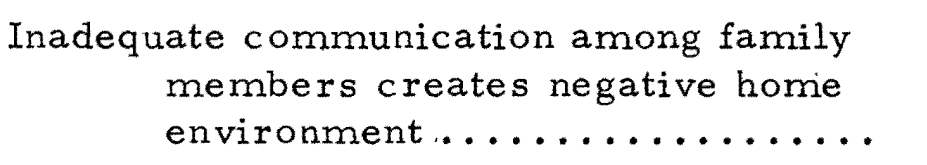 & .73967 & IL \\
\hline $\begin{array}{l}\text { Behaviors learned through inadequate } \\
\qquad \text { family socialization ........... }\end{array}$ & .69043 & IL \\
\hline
\end{tabular}

environment." The third item included in this factor, but not dealing with the dysfunctional family orientation, dealt with "psychological problems such as poor self-image and self-identity." However, the item does fit into our dysfunctional family category as we have formulated it. 
Factor 4: Bio-Psychological Deficiencies. This factor is made up of items which view psychological and biological deficiencies such as poor self-image, lack of personal motivation, or personality disorders, as the causes of delinquency. This deficiency sets the delinquent apart from the non-delinquent. Examples of items in this factor are: "poor sense of morality," which suggests a religious perspective, "poorly formed super-egos," which suggests very early life internalization, and "lack of ability to control anti-social impulses, which suggests biological or mysterious controls.

TABLE VI

BIO-PSYCHOLOGICAL DEFICIENCIES

\begin{tabular}{|c|c|c|}
\hline Item & $\begin{array}{l}\text { Factor } \\
\text { Loading }\end{array}$ & $\begin{array}{l}\text { Hypothetical } \\
\text { Category }\end{array}$ \\
\hline 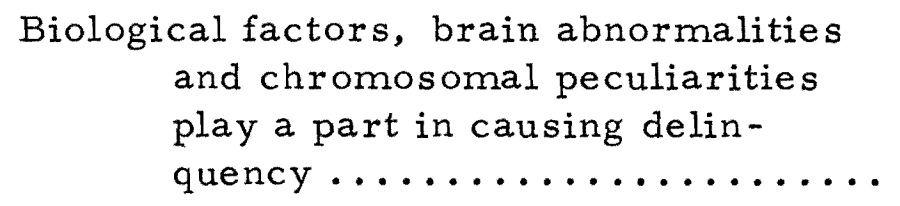 & .52334 & I C \\
\hline $\begin{array}{l}\text { Innate aggression is likely to manifest } \\
\text { itself in delinquency } \ldots \ldots \ldots . . .\end{array}$ & .58332 & IC \\
\hline Lower innate intelligence .......... & .53607 & IC \\
\hline Poor sense of morality ............ & .59780 & IL \\
\hline Poorly formed super-egos .......... & .61720 & IL \\
\hline $\begin{array}{l}\text { Lack of ability to control anti-social } \\
\text { impulses .................. }\end{array}$ & .60984 & IL \\
\hline
\end{tabular}


The analysis indicates that this factor is a mixture of conservative and liberal items. Whereas we distinguished a difference between the biological and psychological factors, i. e., between Paradigm I Conservative and Paradigm I Liberal categories, the respondents did not.

Factor 5: The Permissive Society. The items in this factor represent the permissive society category. The items stress the causes of delinquency to lie within the structural problem orientation, especially the breakdown of traditional institutions. Some examples of the factor items are "a morally permissive society," and "too much questionning of social institutions - lead to delinquency." This factor deals with items of organizational dysfunction, whereas Factor 2 stresses the importance of a reactionary "return to the old values."

TABLE VII

PERMISSIVE SOCIETY

\begin{tabular}{|c|c|c|}
\hline Item & $\begin{array}{l}\text { Factor } \\
\text { Loading }\end{array}$ & $\begin{array}{l}\text { Hypothetical } \\
\text { Category }\end{array}$ \\
\hline \multicolumn{3}{|l|}{ Too much questionning of social } \\
\hline institutions $\ldots \ldots \ldots \ldots \ldots \ldots$ & .74031 & II \\
\hline A morally permissive society $\ldots \ldots \ldots \ldots$ & .59977 & IIC \\
\hline $\begin{array}{l}\text { Values of Ethnic and racial groups pre- } \\
\text { dispose youth to delinquency ..... }\end{array}$ & .61025 & IIC \\
\hline
\end{tabular}


All of the items in the factor represent our organizational dysfunctions category. The respondents indicated agreement with the category that we developed as Paradigm II Conservative. The analysis indicates a close grouping of the items. There was no contamination of the exclusive Paradigm II Conservative category. There was a clear agreement between our category and the respondents.

Factor 6: Labeling and Political Expression. The items in this factor stress the dysfunctional social structure as the cause of delinquency. The items in the factor represent a radical alternative to the traditional approach of describing delinquency. One of the items is "there are no psychological differences between delinquent and non-delinquent youth." Inherent in this statement is the idea that society has set up the distinction between delinquent and non-delinquent individuals, and that causation is due to labeling rather than psychological factors. Another item states "delinquency reflects healthy youth making us aware of problems in the social system." This statement reflects the Marxist idea of delinquency as a political statement of class conflict. 
TABLE VIII

LABELING AND POLITICAL EXPRESSION

\begin{tabular}{|c|c|c|}
\hline Item & $\begin{array}{l}\text { Factor } \\
\text { Loading }\end{array}$ & $\begin{array}{c}\text { Hypothetical } \\
\text { Category }\end{array}$ \\
\hline $\begin{array}{l}\text { No psychological differences between } \\
\text { delinquent and non-delinquent } \\
\text { youth } \ldots \ldots \ldots \ldots \ldots \ldots \ldots \ldots \ldots \ldots \ldots\end{array}$ & .75930 & I I R \\
\hline $\begin{array}{c}\text { Delinquency reflects healthy youth making } \\
\text { us aware of problems in social } \\
\text { system } \ldots \ldots \ldots \ldots \ldots \ldots \ldots \ldots \ldots\end{array}$ & .71256 & I I R \\
\hline
\end{tabular}

Factors Relating to Delinquency Programs

Factor 1: Need for Educational Changes. The items in this factor reflect liberal views that see certain dysfunctions in the system which creates delinquency. However, this view does not see the need for a basic institutional change. Liberal programs aim to change organizations and communities.

All of the items in this factor fit into our Liberal category. Seven of the items represent the Paradigm II Liberal category and one fits the Paradigm I Liberal category. Whereas the Paradigm II Liberal items indicate the need for organizational change, the Paradigm I Liberal item stresses the need for "practical methods for competing in the world." The items reveal a high correlation 
TABLE IX

NEED FOR EDUCATIONAL CHANGES

\begin{tabular}{lll}
\hline Item & $\begin{array}{l}\text { Factor } \\
\text { Loading }\end{array}$ & $\begin{array}{c}\text { Hypothetical } \\
\text { Category }\end{array}$ \\
\hline
\end{tabular}

Educate public about societal conditions negating the ability of youth to reach potential ................. . 59096

IIL

Encourage business community to increase employment ...............69639 IIL

Create meaningful work and educational opportunities .............. . 54519

Address breakdown in socializing influences............... .62830 IIL

Stress practical methods for competition

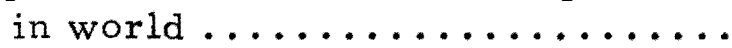
.63954

Programs should work closely with schools to detect potential delinquencies ... . .63887 IIL

Provide means to assure status of youth ................... .64679 IIL

Work closely with schools to make them more receptive to youth ....... . . 58444 II L

among the seven items in the Paradigm II Liberal category. They reflect community, organizational and educational tasks for delinquency prevention. 
Factor 2: No Need for Changing Laws Relating to Youth. The items in this category represent a conservative perspective to programs of delinquency prevention. These items stress the need for not changing the institutions of the societal structure.

TABLE X

NO NEED FOR CHANGING LAWS RELATING TO YOUTH

\begin{tabular}{|c|c|c|}
\hline Item & $\begin{array}{l}\text { Factor } \\
\text { Loading }\end{array}$ & $\begin{array}{l}\text { Hypothetical } \\
\text { Category }\end{array}$ \\
\hline $\begin{array}{c}\text { Traditional values should be supported } \\
\text { by programs } \ldots \ldots \ldots \ldots \ldots \ldots\end{array}$ & .57040 & IIC \\
\hline $\begin{array}{l}\text { Adopt policies of greater diversity in } \\
\text { youth behavior } \ldots \ldots \ldots \ldots \ldots \ldots\end{array}$ & -.50074 & I I R \\
\hline $\begin{array}{l}\text { Conduct illegal only for minor should } \\
\text { be eliminated } \ldots \ldots \ldots \ldots \ldots \ldots\end{array}$ & -.67870 & I I R \\
\hline $\begin{aligned} \text { Every child should have right to } \\
\text { refuse treatment } \ldots \ldots \ldots \ldots\end{aligned}$ & -.65936 & I I R \\
\hline
\end{tabular}

The analysis indicates that three of four items in the factor fit into our Radical category. While the respondents disagreed with the Radical category, they included an item which we had designated a Conservative statement. However, the items of the Radical category and the Conservative item, were negatively correlated. In other words, while they tended to agree with the Conservative item, they disagreed with the Radical items. This suggests a conservative 
inclination on the part of the respondents.

Factor 3: Direct Family Services. The items in this factor represent the category of direct family services. The emphasis of the items is on the importance of psychological counseling for the individual and family.

TABLE XI

DIRECT FAMILY SERVICES

\begin{tabular}{lll}
\hline \hline Item & $\begin{array}{l}\text { Factor } \\
\text { Loading }\end{array}$ & $\begin{array}{c}\text { Hypothetical } \\
\text { Category }\end{array}$ \\
\hline
\end{tabular}

Heart of problem is good individual and family counseling .......... .58668 IL

We should apply family counseling and the rapy techniques ......... .6. .69266 II

The items in this factor all fit into our direct family service category. The respondents agreed with our category and clearly placed the items into it. There was no cross-over in categories in this factor, as all respondents answered in an exclusive manner.

Factor 4: Positive Sentiments Towards Individual's Ability to Change. The items in this factor indicate that programs should emphasize assisting the individual. The program should concentrate on the emotional needs of youth. The items fall into our personal 
deficiency perspectives.

TABLE XII

POSITIVE SENTIMENTS TOWARD INDIVIDUALS' ABILITY

TO CHANGE

\begin{tabular}{|c|c|c|}
\hline Item & $\begin{array}{l}\text { Factor } \\
\text { Loading }\end{array}$ & $\begin{array}{c}\text { Hypothetical } \\
\text { Category }\end{array}$ \\
\hline $\begin{array}{l}\text { Some youth are so set in their ways that } \\
\text { little can be done to change them.. }\end{array}$ & -.55261 & I C \\
\hline $\begin{array}{l}\text { Programs should support the emotional } \\
\text { needs of youth } \ldots \ldots \ldots \ldots\end{array}$ & .55428 & I L \\
\hline
\end{tabular}

The items illustrate a negative correlation between a conservative item and a liberal one. This negative correlation reveals an internal consistency in the questionnaire and support for the distinction between our Conservative and Liberal categories.

Factor 5: The Need For Individual and Organizational Change. The items in this factor reflect the liberal view that programs should stress both individual and organizational change. The view does not see the need for basic institutional change.

All the items reflect the liberal perspective. The respondents combined three Paradigm I Liberal items and two Paradigm II Liberal items. There was a high agreement with the Liberal items which emphasized individual and family counseling. However, the 
TABLE XIII

THE NEED FOR INDIVIDUAL AND

ORGANIZATIONAL CHANGE

\begin{tabular}{|c|c|c|}
\hline Item & $\begin{array}{l}\text { Factor } \\
\text { Loading }\end{array}$ & $\begin{array}{l}\text { Hypothetical } \\
\text { Category }\end{array}$ \\
\hline $\begin{array}{l}\text { When programs fail, it is an indication } \\
\text { to improve counseling and case- } \\
\text { work techniques } \ldots \ldots \ldots \ldots \ldots \ldots\end{array}$ & .62250 & IL \\
\hline $\begin{array}{l}\text { When programs fail, it is because of a } \\
\text { lack of community resources .... }\end{array}$ & .59298 & I I L \\
\hline $\begin{array}{l}\text { Programs should attempt to create } \\
\text { meaningful work ............ }\end{array}$ & .55210 & IIL \\
\hline $\begin{array}{r}\text { Programs should support emotional } \\
\text { needs of youth } \ldots \ldots \ldots \ldots \ldots \ldots\end{array}$ & .55428 & IL \\
\hline $\begin{array}{l}\text { Programs should stimulate better family } \\
\text { functioning } \ldots \ldots \ldots \ldots \ldots \ldots \ldots\end{array}$ & .56167 & I L \\
\hline
\end{tabular}

respondents included liberal items which stressed programs involving an organizational change. The factor did not clearly distinguish the Paradigm I Liberal and Paradigm II Liberal categories. Perhaps, the paradigms are not thought of as separate constructs to the respondents.

Factor 6: Cynicism Toward Programs for Youth. The items in this factor reflect the necessity of a basic institutional change orientation for programs. 
TABLE XIV

CYNICISM TOWARD PROGRAMS FOR YOUTH

\begin{tabular}{|c|c|c|}
\hline Item & $\begin{array}{l}\text { Factor } \\
\text { Loading } \\
\end{array}$ & $\begin{array}{c}\text { Hypothetical } \\
\text { Category } \\
\end{array}$ \\
\hline $\begin{array}{l}\text { Programs have failed to demonstrate } \\
\text { effectiveness } \ldots \ldots \ldots \ldots \ldots \ldots\end{array}$ & .70216 & I I R \\
\hline $\begin{array}{l}\text { It is unlikely that any program can really } \\
\text { eliminate delinquency } \ldots \ldots \ldots . .\end{array}$ & .59689 & I I R \\
\hline
\end{tabular}

The items in this factor indicate a high correlation with cynicism toward programs for youth. The underlying assumption is that delinquency is caused by institutional variables and no program can stop delinquency until the society is changed.

Factors Relating to the Role of the Worker

Factor 1: Job Preparation. The items in this factor emphasize the Liberal perspective. They stress the importance of changing the individual or organization, but not the institutions.

The factor contains two items, one which has a positive loading and one with a negative loading. The positive statement fits the Paradigm I Liberal category, while the negative statement corresponds to the Paradigm II Liberal category. The respondents indicated that they should refer clients to other agencies, but that 
TABLE XV

JOB PREPARATION

\begin{tabular}{|c|c|c|}
\hline Item & $\begin{array}{l}\text { Factor } \\
\text { Loading }\end{array}$ & $\begin{array}{l}\text { Hypothetical } \\
\text { Category }\end{array}$ \\
\hline $\begin{array}{l}\text { Workers should know the resources of } \\
\text { community and refer clients } \\
\text { there when worker cannot offer } \\
\text { the service } \ldots \ldots \ldots \ldots \ldots \ldots \ldots\end{array}$ & .55192 & I L \\
\hline $\begin{array}{l}\text { Prepare youth for locating jobs rather } \\
\text { than counseling .............. }\end{array}$ & -.67889 & II L \\
\hline
\end{tabular}

they should counsel clients rather than develop jobs for them.

Factor 2: Role as Counselors. This factor emphasizes the worker's role as counselor. The items in the factor stress the responsibility of the individual and the assisting of youth in developing inter-personal, communication, educational and training experiences. The items all fit into the category of "role as counselor." The loadings are all positively correlated to one another. The items clearly indicate that the respondents agree with our category. All the items stressed the person-centered, psychologically-based interventions. There were no cross-overs of categories in this factor. The respondents answered in an exclusive manner the items in this factor. 
TABLE XVI

ROLE AS COUNSELORS

\begin{tabular}{|c|c|c|}
\hline Item & $\begin{array}{l}\text { Factor } \\
\text { Loading }\end{array}$ & $\begin{array}{l}\text { Hypothetical } \\
\text { Category }\end{array}$ \\
\hline $\begin{array}{l}\text { Obtain assistance of offender's } \\
\qquad \text { family and friends ........... }\end{array}$ & .68197 & IL \\
\hline Self responsibility is good to stress .... & .59533 & II \\
\hline $\begin{array}{l}\text { Stress importance of educational/ } \\
\text { training experiences ........... }\end{array}$ & .60886 & IL \\
\hline $\begin{array}{l}\text { Assist youth in developing interpersonal } \\
\text { and communication skills ....... }\end{array}$ & .52916 & IL \\
\hline $\begin{array}{l}\text { Professional practice to work with } \\
\qquad \begin{array}{l}\text { offenders in schools and } \\
\text { neighborhoods } \ldots \ldots \ldots \ldots \ldots \ldots\end{array}\end{array}$ & .62898 & I I \\
\hline
\end{tabular}

Factor 3: Worker as Activist. The items in this factor stress an activist, change-oriented role for the worker. The items call for a change in the basic institutional arrangements of society. All the items fit into the Radical category; four items were Paradigm II Radical and one item was Paradigm I Liberal. All the items stressed the need for institutional change. The respondents indicated agreement with the built-in category. The four Paradigm II Radical items emphasized the need for institutional change while Paradigm I Radical statement stressed the need for 
TABLE XVII

WORKER AS ACTIVIST

\begin{tabular}{|c|c|c|}
\hline Item & $\begin{array}{l}\text { Factor } \\
\text { Loading }\end{array}$ & $\begin{array}{l}\text { Hypothetical } \\
\text { Category }\end{array}$ \\
\hline $\begin{array}{l}\text { Workers should involve themselves } \\
\text { in political process } \ldots \ldots \ldots \ldots\end{array}$ & .61393 & II R \\
\hline Organize other workers around issues .. & .61393 & II $\mathrm{R}$ \\
\hline $\begin{array}{c}\text { Workers should help offenders understand } \\
\text { their behavior is a function of } \\
\text { blocked opportunity } \ldots \ldots \ldots \ldots\end{array}$ & .58596 & I I $R$ \\
\hline Reform of agency $\ldots \ldots \ldots \ldots \ldots \ldots$ & .62734 & II $\mathrm{R}$ \\
\hline $\begin{array}{c}\text { Disseminate information on injustices of } \\
\text { justice system } \ldots \ldots \ldots \ldots \ldots \ldots\end{array}$ & .64919 & I I $R$ \\
\hline
\end{tabular}

raising the consciousness of the client. However, the items do indicate a clear Paradigm II Radical category.

Factor 4: Agency Constraints. The items in this factor deal with the attitudes regarding agency guidelines.

This factor contains two items negatively correlated with each other. The Conservative and Radical items tend to indicate an internal consistency of the se categories. 
TABLE XVIII

AGENCY CONSTRAINTS

\begin{tabular}{|c|c|c|}
\hline Item & $\begin{array}{l}\text { Factor } \\
\text { Loading }\end{array}$ & $\begin{array}{c}\text { Hypothetical } \\
\text { Category }\end{array}$ \\
\hline Stay within agency guidelines ........ & .68269 & I C \\
\hline "Bend" agency policies ............ & -.65961 & II R \\
\hline
\end{tabular}

Factor 5: "Return to Old Values." The items in this factor fit into our "return to old values" category. They stress the traditional values of society. The items indicate the role of the worker to be to stress a return to those "old" values. Some examples are "stress the 'old' values since they represent the backbone of society," and "stress the traditional values of family solidarity."

TABLE XIX

RETURN TO OLD VALUES

\begin{tabular}{|c|c|c|}
\hline Item & $\begin{array}{l}\text { Factor } \\
\text { Loading } \\
\end{array}$ & $\begin{array}{l}\text { Hypothetical } \\
\text { Category } \\
\end{array}$ \\
\hline $\begin{array}{l}\text { Stress traditional values of family } \\
\text { solidarity } \ldots \ldots \ldots \ldots \ldots \ldots \ldots\end{array}$ & .69712 & I I C \\
\hline $\begin{array}{c}\text { Stress "old" values since they represent } \\
\text { the backbone of society } \ldots \ldots \ldots\end{array}$ & .74197 & I I C \\
\hline
\end{tabular}


This factor contains two "return to old values" items. Both are positively correlated in this factor. The respondents tended to agree with this built-in category. They answered in an exlusive manner the items in this factor.

Factor 6: Community Involvement. The items in this factor emphasize the role of the worker as linking clients with organizations, developing job opportunities, and involving communities in change. The items stress an organizational change but not any institutional change. Examples are "develop job opportunities for youth," "link clients to organizationa," and "develop community resources."

TABLE XX

COMMUNITY INVOLVEMENT

\begin{tabular}{|c|c|c|}
\hline Item & $\begin{array}{l}\text { Factor } \\
\text { Loading }\end{array}$ & $\begin{array}{l}\text { Hypothetical } \\
\text { Category }\end{array}$ \\
\hline $\begin{array}{l}\text { Speak to leaders of community about } \\
\text { their responsibility in the } \\
\text { solution of delinquency } \ldots \ldots \ldots \ldots\end{array}$ & .60184 & II L \\
\hline $\begin{array}{l}\text { Talk with business people about the role } \\
\text { of business in helping delinquents.. }\end{array}$ & .67281 & IIL \\
\hline Develop job opportunities for youth ...... & .70688 & IIL \\
\hline Develop community resources ......... & .57480 & IIL \\
\hline $\begin{array}{l}\text { Advocacy techniques should be used } \\
\text { extensively } \ldots \ldots \ldots \ldots \ldots \ldots \ldots\end{array}$ & .54828 & IIL \\
\hline Link clients to organizations . . . . . . . & .82461 & II L \\
\hline
\end{tabular}


All the items fit our Community Involvement category. The factor contains six items positively correlated with each other. The respondents tended to agree with this built-in category. This factor is a clear indicator of the category of Paradigm II Liberal.

\section{SUMMARY OF FACTORS}

Our questionnaire was developed within the framework of Warren's Paradigm I and Paradigm II. We further elaborated the two main Paradigms with categories of Conservative, Liberal, and Radical. Each item in the questionnaire fit one of the six theoretical categories. The full description of each category appears in the Methodology chapter.

The questionnaire was divided into three content sections. Each section contained items eliciting the attitudes of the workers about: 1) Causes of delinquency, 2) programs of juvenile prevention, and 3) the Role of the Worker with delinquents. All six categories were represented in items within the three content areas.

We then applied a factor analysis to our collected date. We expected that six distinct categories would be extracted. For the most part, the extracted factors matched our hypothetical categories. However, we did not find six exclusive categories. In addition, there was overlap in some factors of the categories.

The section, "Causes of Delinquency," revealed four distinct 
factors containing items of an exclusive category. Two factors contained only Paradigm II Radical items (Dysfunctional Social Structure and Labeling and Political Expression). Two factors contained only Paradigm II Conservative items (Return to Old Values and Permissive Society). The other two factors contained an overlap of categories. However, both factors contained one category that was dominant in that factor.

The section relating to factors on delinquency programs contained two factors that were exclusively represented by a single category, Direct Family Services (Paradigm I Liberal) and Cynicism toward programs for youth (Paradigm II Radical). One factor, Need for Educational Changes, contained all Liberal items: seven Paradigm II Liberal, and one Paradigm I Liberal. Another factor, The Need for Individual and Organizational change, also contained all Liberal items: two Paradigm II Liberal and three Paradigm I Liberal. Two factors, No Need for Changing Laws Relating to Youth and Positive Sentiments toward Individual's Ability to Change, contained items that were negatively correlated with one another. This relationship indicated that while the sample tended to agree with one item they disagreed with the other. The items which they agreed with were of the Conservative categories, thus giving the two factors a Conservative character.

The section relating to the Role of the Worker yielded four 
factors that contained items of an exclusive category. They were:

1) Role as Counselor - Paradigm I Liberal, 2) Worker as Activist Paradigm II Radical, 3) Return to Old Values - Paradigm II Conservative, and 4) Community Involvement - Paradigm II Liberal. The other two factors contained items that were negatively correlated. One factor, Job Preparation, contained Liberal items but the sample agreed with the item of Paradigm I and disagreed with the Paradigm II thus indicating an individual change but not an institutional change. The last factor, Agency Constraints, also contained items negatively correlated. This factor tended to support a Conservative stance as well.

Overall, most of our hypothetical categories were validated by the factor analysis. However, more research needs to be done around the factors that contained more than one category.

\section{DESCRIPTION OF FINDINGS}

Introduction to Findings

The previous section described the comparison between the hypothesized categories and the actual categories that were extracted by the factor analysis.

This section will describe the factors in relation to the agreement/disagreement of the respondents to our perceived categories. The mean response of the sample to each item will indicate 
agreement/disagreement with the item. The variance in response will be shown by the standard deviation.

A Likert-type scale was used to measure the response of each item. The scale ranged from a "1", meaning strongly agree, to a "7", meaning strongly disagree. A "4" divided the scale by meaning neither agree nor disagree.

As the following description will show, the sample tends to respond in our Paradigm I Liberal category. That is, they tend to view the individual as deficient, either psychologically or behaviorally. They see the mode of treatment to be one of changing the individual through therapy and counseling.

Factors Relating to the Causes of Delinquency

Factor 1: Dysfunctional Social Structure. In examining the responses of the sample to this factor, a Radical perspective to the organization of the social structure, we find a slight agreement to the items. However, as the items reflect a more radical perspective, the mean approaches the 4.0 rating - neither agree nor disagree; the midpoint of the scale. This could reflect a refusal to commit oneself, a middle of the road attitude rather than no opinion to the statement. We think it is the former explanation. It is interesting to note that the respondents on the average would not indicate an opinion on Radical statements, though the standard deviation of 1.5 
TABLE XXI

DYSFUNCTIONAL SOCIAL STRUCTURES

\begin{tabular}{|c|c|c|c|}
\hline Item & $\begin{array}{l}\text { Hypothesized } \\
\text { Category }\end{array}$ & $\begin{array}{l}\text { Mean } \\
\text { Response }\end{array}$ & $\begin{array}{l}\text { Standard } \\
\text { Deviation }\end{array}$ \\
\hline $\begin{array}{l}\text { Society provides few meaning }- \\
\quad \text { ful roles for youth } \ldots \ldots \ldots \ldots\end{array}$ & IIR & 3.06 & 1.70 \\
\hline $\begin{array}{l}\text { Police and Justice system } \\
\quad \text { create delinquents ......... }\end{array}$ & IIR & 3.37 & 1.56 \\
\hline $\begin{array}{l}\text { Competitive norms and values } \\
\text { of economic system } \ldots \ldots \ldots\end{array}$ & IIR & 3.82 & 1.33 \\
\hline $\begin{array}{l}\text { Until the social system employ- } \\
\text { ment, we can expect } \\
\text { delinquency } \ldots \ldots \ldots \ldots \ldots \ldots\end{array}$ & IIR & 4.01 & 1.52 \\
\hline $\begin{array}{l}\text { Capitalism cannot function without } \\
\text { a poverty class that contributes } \\
\text { to delinquency } \ldots \ldots \ldots \ldots \ldots\end{array}$ & IIR & 3.72 & 1. 58. \\
\hline
\end{tabular}

suggests a wider variance around the mean. The fact that there was not the expected disagreement with the Radical statements, perhaps indicates a lack of understanding of these issues among delinquency workers.

Factor 2: Return to Old Values. This factor shows a clear grouping of Conservative statements and general agreement with all of the statements. There is fairly strong agreement with statements expressing a "return to old values" (lack of firm parental discipline, 
TABLE XXII

RETURN TO OLD VALUES

\begin{tabular}{|c|c|c|c|}
\hline Item & $\begin{array}{l}\text { Hypothesized } \\
\text { Category }\end{array}$ & $\begin{array}{l}\text { Mean } \\
\text { Response } \\
\end{array}$ & $\begin{array}{l}\text { Standard } \\
\text { Deviation } \\
\end{array}$ \\
\hline 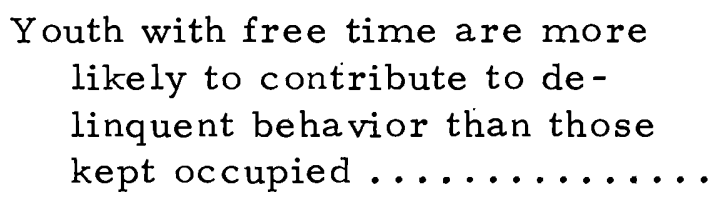 & IIC & 3.17 & 1.49 \\
\hline $\begin{array}{l}\text { Lack of firm parental discipline } \\
\text { is a factor } \ldots \ldots \ldots \ldots \ldots \ldots\end{array}$ & IIC & 2.72 & 1.27 \\
\hline $\begin{array}{l}\text { A morally permissive society sets } \\
\text { the stage for delinquency ..... }\end{array}$ & IIC & 3.87 & 1.57 \\
\hline $\begin{array}{l}\text { Peer Group pressure frequently } \\
\text { causes delinquent behavior ... }\end{array}$ & IIC & 2.35 & .90 \\
\hline
\end{tabular}

$\bar{x}=2.72$ ), and with a statement relating to the peer group (peer group pressure causes delinquent behavior, $\bar{x}=2.35$ ). This factor indicates that the sample felt that a return to the traditional values would result in less delinquency.

Factor 3: Dysfunctional Families. There is a grouping of five statements in this factor. Four of these statements relate to the influence of dysfunctional family environment in causing delinquency.

There was generally high agreement indicated by low mean scores and small standard deviations with statements dealing with 
TABLE XXIII

DYSFUNCTIONAL FAMILIES

\begin{tabular}{llll}
\hline Item & $\begin{array}{l}\text { Hypothesized } \\
\text { Category }\end{array}$ & $\begin{array}{l}\text { Mean } \\
\text { Response }\end{array}$ & $\begin{array}{l}\text { Standard } \\
\text { Ceviation }\end{array}$ \\
\hline
\end{tabular}

Delinquency is caused by a breakdown in community relations .............. IIL $2.68 \quad 1.21$

A youth's immediate environment, especially poor family relationships and negative peer influence. IIC

Psychological problems as poor selfimage and self-identity ..... IL $\quad$ IL $1.86 \quad .80$

Unstable dysfunctional family environments .......... IL IL $2.46 \quad 1.17$

Lack of good parenting skills .... IL IL $\quad 2.53 \quad 1.29$

Inadequate communication among family members creates negative home environment .......

Behaviors learned through inadequate family socialization.. II $\quad 3.28 \quad 1.33$

the influences of family and peers (a youth's immediate environment, especially peer family relationships and negative peer influences, $\bar{x}=1.68$, S.D. $=.87$ ). This statement was categorized as representing the Paradigm I Liberal perspective which emphasizes the effect of the youth's immediate environment. Overall, this factor relates to the causative influence of immediate environment. Overall, 
this factor relates to the causative influence of immediate environmental influences, especially the family. There was a consistently strong pattern of agreement with the se Paradigm I Liberal statements (average mean $=2.0)$.

TABLE XXIV

BIO-PSYCHOLOGICAL DEFICIENCIES

\begin{tabular}{llll}
\hline Item & $\begin{array}{l}\text { Hypothesized } \\
\text { Category }\end{array}$ & $\begin{array}{l}\text { Mean } \\
\text { Responses }\end{array}$ & $\begin{array}{l}\text { Standard } \\
\text { Deviation }\end{array}$ \\
\hline
\end{tabular}

Biological factors, brain abnormalities and chromosomal peculiarities play a part in causing delinquency ...... IC $\quad$ IC $\quad 4.68 \quad 1.58$

Innate aggression is likely to manifest itself in delinquency .. IC IC $\quad 3.33 \quad 1.51$

Lower innate intelligence ...... IC IC $\quad 4.54 \quad 1.55$

Poor sense of morality ........ IL IL $3.12 \quad 1.30$

Poorly formed superegos ....... II I $\quad 2.93 \quad 1.38$

Lack of ability to control antisocial impulses.......... II $\quad 3.00$ IL 1.43

Factor 4: Bio-Psychological Deficiencies. There is fairly strong agreement with these statements reflecting psychological influences (poor sense of morality, $\bar{x}=3.12$; poor superego, $\bar{x}=2.93$; lack of control of anti-social impulses, $\bar{x}=3.0$ ). The responses to these psychological factors reveals a preference for psychological 
terms such as "superego."

There is an interesting trend towards disagreement with the bio-psychological deficiencies statements which indicates hereditary predisposition to delinquency (biological factors, $\overline{\mathrm{x}}=4.68$; lower innate intelligence, $\vec{x}=4.54$ ). The mean response of the sample showed disagreement with the most conservative causation theories.

\section{TABLE XXV}

THE PERMISSIVE SOCIETY

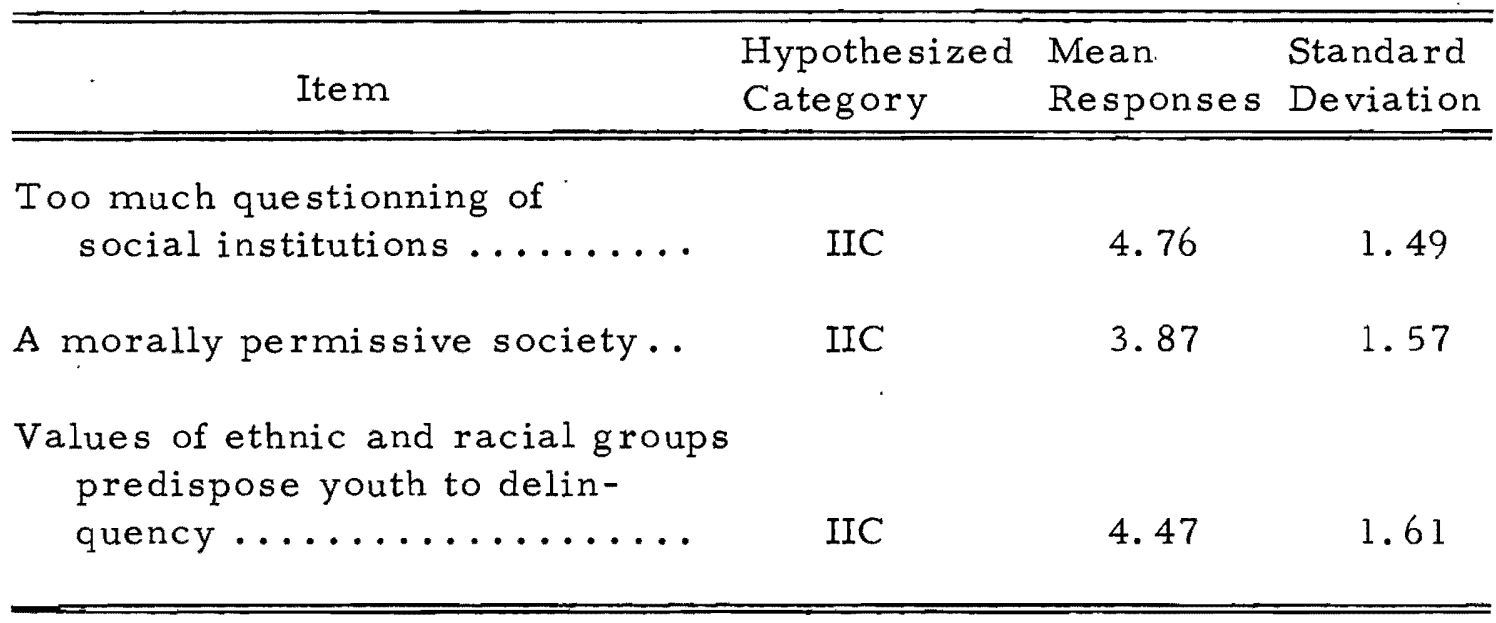

Factor 5: The Permissive Society. Our sample showed a slight trend towards disagreement with the se statements which reflected the breakdown and negative influence of organization. This is in contrast to the general agreement with statements in Factor 2 which deal more directly with the breakdown in the family (values of ethnic and racial groups predispose youth to delinquency, $\bar{x}=4.47$ ). This might be interpreted as another example of our respondents 
tending to disagree with the most conservative and most radical statements. In this case, perhaps there was an inclination not to agree with a statement which might be construed as racist. There was slight agreement with another conservative statement (a morally permissive society sets the stage for delinquency, $\bar{x}=3.81$ ). Here there is a willingness to look at the social structural effects from a conservative perspective.

TABLE XXVI

LABELING AND POLITICAL EXPRESSION

\begin{tabular}{llll}
\hline Item & $\begin{array}{l}\text { Hypothesized } \\
\text { Category }\end{array}$ & $\begin{array}{l}\text { Mean } \\
\text { Responses }\end{array}$ & $\begin{array}{l}\text { Standard } \\
\text { Deviation }\end{array}$ \\
\hline
\end{tabular}

No psychological differences delinquent and nondelinquent youth ......... IIR $\quad 4.75 \quad 1.51$

Delinquency reflects healthy youth making us aware of problems in social system ......... IIR IR $4.24 \quad 1.51$

Factor 6: Labeling.and Political Expression. Our sample showed the highest disagreement with the two statements in this factor (there are no psychological differences between delinquent and non-delinquent youth, $(\bar{x}=4.75$; delinquency reflects healthy youth making us aware of problems in the social system, $\vec{x}=4.24$ ).

The respondents disagreed with these two radical statements 
which emphasized labeling and political expression. It is interesting to note this disagreement with statements that imply the delinquent is entitled to an opinion about her/his own problems.

TABLE XXVII

NEED FOR EDUCATIONAL CHANGE

\begin{tabular}{llll}
\hline Item & $\begin{array}{l}\text { Hypothesized } \\
\text { Category }\end{array}$ & $\begin{array}{l}\text { Mean } \\
\text { Responses }\end{array}$ & Standard \\
& Deviation \\
\hline
\end{tabular}

Educate public about societal conditions negating the ability of youth to reach their po-

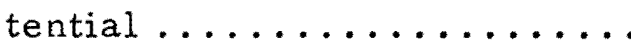

IIL 2.88 1.26

Encourage business community to increase employment ......

Create meaningful work and educational opportunities ......

Address the breakdown in socializing influences .......

Stress practical methods for competition in world ....... IIL

Programs should work closely with schools to detect potential

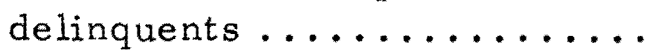

Provide means to restore status

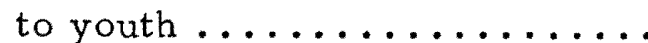

Work closely with schools to make them more receptive to youth.. IIL 2.73 1.15 
Factors Relating to Delinquency Programs

Factor 1: Need for Educational Change. There was strong agreement with these statements which emphasize educational programs and organizational tasks. This trend of agreement (average mean $=2.5)$ shows a commitment on the part of our respondents to working with schools and emphasizing practical, work-related activities. These statements are categorized because of the emphasis on organization in the community to prevent delinquency. In this area of organizational change, our sample agreed that programs should be involved.

TABLE XXVIII

NO NEED FOR CHANGING LAWS RELATING TO YOUTH

\begin{tabular}{clll}
\hline Item & $\begin{array}{l}\text { Hypothesized } \\
\text { Category }\end{array}$ & $\begin{array}{l}\text { Mean } \\
\text { Responses }\end{array}$ & $\begin{array}{l}\text { Standard } \\
\text { Deviation }\end{array}$ \\
\hline \hline
\end{tabular}

Traditional values should be supported by programs ..... IIC $\quad 3.55 \quad 1.25$

Adopt policies of greater diversity in youth behavior ....... IIR $\quad 3.53 \quad 1.50$

Conduct illegal only for minor should be eliminated ....... IIR $\quad 4.08 \quad 1.89$

Every child should have right to re fuse treatment ........... IIR $\quad 4.20 \quad 1.95$ 
Factor 2: No Need for Changing Laws Relating to Youth. This factor showed our sample disagreed with accepting a greater range of behavior from juveniles. This indicates a disappointing lack of support among workers for changes in legislation to remove status offenses and uphold children's rights. There was slight agreement with Conservative statement (traditional values should be supported, $\bar{x}=3.55)$ in contrast to disagreement with statements encouraging social reform and legislative action (conduct illegal only for minors should be eliminated, $\bar{x}=4.08)$.

TABLE XXIX

FAMILY SERVICES

\begin{tabular}{llcc}
\hline \hline \multicolumn{1}{c}{ Item } & $\begin{array}{l}\text { Hypothesized } \\
\text { Category }\end{array}$ & $\begin{array}{l}\text { Mean } \\
\text { Responses }\end{array}$ & $\begin{array}{c}\text { Standard } \\
\text { Deviation }\end{array}$ \\
$\begin{array}{c}\text { Heart of program is good family } \\
\text { and individual counseling .... }\end{array}$ & IL & 2.96 & 1.36 \\
$\begin{array}{l}\text { We should apply family counseling } \\
\text { and the rapy techniques ...... }\end{array}$ & IL & 2.46 & 1.11 \\
$\begin{array}{l}\text { We should apply psychological } \\
\text { counseling and the rapy ...... }\end{array}$ & IL & 3.18 & 1.24 \\
\hline
\end{tabular}

Factor 3: Family Services. There was overall agreement (average mean $=3.0)$ with those statements emphasizing individual and family therapy. The sample again showed consistent agreement 
with Family Service statements emphasizing individual casework services.

TABLE XXX

POSITIVE SENTIMENTS TOWARD INDIVIDUAL'S

ABILITY TO CHANGE

\begin{tabular}{llll}
\hline Item & $\begin{array}{l}\text { Hypothesized } \\
\text { Category }\end{array}$ & $\begin{array}{l}\text { Mean } \\
\text { Responses }\end{array}$ & Deviatadion \\
\hline
\end{tabular}

Some youth are so set in their ways that little can be done to change them............. IC $4.41 \quad 1.62$

Programs should support emotional needs of youth $\ldots \ldots \ldots \ldots \ldots$ II $\quad 1.77 \quad .82$

Factor 4: Positive Sentiments Toward Individual's Ability

to Change. There is high agreement with the notion that programs should support the emotional needs of youth $(\bar{x}=1.77)$. There was, in contrast, disagreement with the Conservative statement that many youth are so set in their ways that little can be done to change them $(\bar{x}=4.41)$.

Factor 5: The Need For Individual and Organizational Change. There was a progressively higher rate agreement with statements indicating programs should support the emotional needs of youth $(\bar{x}=1.77)$. There was a lower agreement score with "when programs 
TABLE XXXI

THE NEED FOR INDIVIDUAL AND

ORGANIZATIONAL CHANGE

\begin{tabular}{llll}
\hline Item & $\begin{array}{l}\text { Hypothesized } \\
\text { Category }\end{array}$ & $\begin{array}{l}\text { Mean } \\
\text { Responses }\end{array}$ & Seviandard \\
\hline
\end{tabular}

When programs fail it is an

indication to improve coun-

seling and casework

techniques ............... II $\quad 3.60 \quad 1.37$

When programs fail, it is because

of a lack of community resources. IIL $\quad 3.08 \quad 1.28$

Programs should attempt to create

meaningful work ...........IIL $2.34 \quad 1.08$

Programs should support

emotional needs of youth ....... IL $\quad 1.77 \quad 82$

Programs should stimulate better

family functioning .......... IL IL 1.56 . 75

fail, it is because of a lack of community resources, " ( $\bar{x}=3.08)$.

Again, this pattern shows an emphasis on casework services

and counseling in juvenile delinquency programs.

Factor 6: Cynicism Towards Programs For Youth. The

sample showed slight agreement with these two statements critical

of delinquency programs (programs have failed, $\bar{x}=3.28$; no pro-

grams can eliminate delinquency, $\bar{x}=2.7$ ). The underlying 
TABLE XXXII

CYNICISM TOWARDS PROGRAMS FOR YOUTH'

\begin{tabular}{|c|c|c|c|}
\hline Item & $\begin{array}{l}\text { Hypothesized } \\
\text { Category }\end{array}$ & $\begin{array}{l}\text { Mean } \\
\text { Responses }\end{array}$ & $\begin{array}{l}\text { Standard } \\
\text { Deviation }\end{array}$ \\
\hline $\begin{array}{l}\text { Programs have failed to } \\
\text { demonstrate effectiveness .... }\end{array}$ & IIR & 3.20 & 1.44 \\
\hline $\begin{array}{l}\text { It is unlikely that any program } \\
\text { can eliminate delinquency .... }\end{array}$ & IIR & 2.77 & 1.51 \\
\hline
\end{tabular}

assumption of these statements is that delinquency is caused by institutional variables and no program can stop delinquency until the society is changed. The responses show a realistic pessimism among workers regarding program effectiveness. However, analysis of previous responses does not suggest a conscious radical perspective towards social change among our respondents. Our sample may disagree as an indication of their dissatisfaction with their own job or program, rather than a focus on institutional change.

Factors Relating to the Role of the Worker

Factor 1: Job Preparation. Workers agreed that they should know the resources of the community $(\bar{x}=1.40)$. However, they were quite reluctant to work on preparing youth for locating jobs rather than providing counseling $(\bar{x}=4.79)$. Workers continue to 


\section{TABLE XXXIII}

JOB PREPARATION

\begin{tabular}{llll}
\hline Item & $\begin{array}{l}\text { Hypothesized } \\
\text { Category }\end{array}$ & $\begin{array}{l}\text { Mean } \\
\text { Response }\end{array}$ & $\begin{array}{l}\text { Standard } \\
\text { Deviation }\end{array}$ \\
\hline
\end{tabular}

Workers should know resources of community and refer clients when worker cannot offer services ............. IL 1.40 .60

Prepare youth for locating jobs rather than counseling ...... IIL 4. 79 1. 10

show a preference for Liberal activities of casework and counseling, though the activities do include knowing community resources and referring clients to them.

Factor 2: Role as Counselor. There is an overall strong agreement with those statements stressing person-centered, psychologically-based interventions. This factor clearly represents the Liberal category with its emphasis on the individual and assisting youth with communication and educational experiences. 
TABLE XXXIV

ROLE AS COUNSELOR

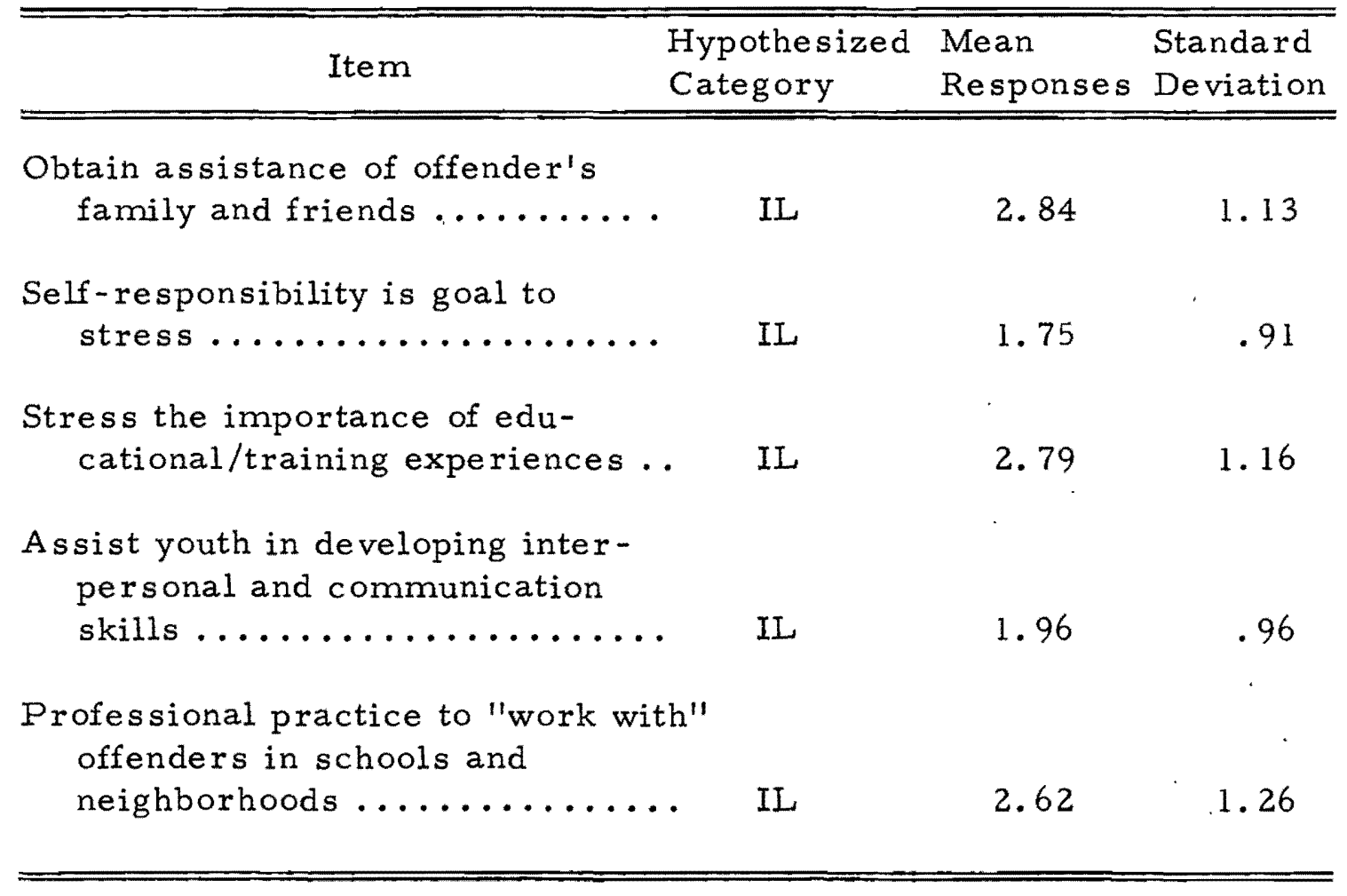

Factor 3: Workers as Activists. There was disagreement with statements reflecting political activity and increasing the critical understanding of clients. There was a trend towards disagreement with items having more to do with impacting on the society (workers should involve themselves in political process, $\bar{x}=4.36$; help youth understand their behavior as a function of blocked opportunity, $\vec{x}=4.28$; disseminate information on injustices of juvenile justice system, $\bar{x}=4.26$ ). 
TABLE XXXV

WORKERS AS ACTIVISTS

\begin{tabular}{|c|c|c|c|}
\hline Item & $\begin{array}{l}\text { Hypothesized } \\
\text { Category }\end{array}$ & $\begin{array}{l}\text { Mean } \\
\text { Responses }\end{array}$ & $\begin{array}{l}\text { Standard } \\
\text { Deviation }\end{array}$ \\
\hline $\begin{array}{l}\text { Workers should involve them- } \\
\text { selves in political process ... }\end{array}$ & IIR & 4.36 & 1.48 \\
\hline $\begin{array}{l}\text { Organize other workers around } \\
\text { issues } \ldots \ldots \ldots \ldots \ldots \ldots \ldots\end{array}$ & IIR & 3.13 & 1.34 \\
\hline $\begin{array}{l}\text { Workers should help offenders } \\
\text { to understand their behavior is } \\
\text { a function of blocked oppor- } \\
\text { tunity } \ldots \ldots \ldots \ldots \ldots \ldots \ldots \ldots\end{array}$ & IR & 4.28 & 1.26 \\
\hline Reform of agency $\ldots \ldots \ldots \ldots \ldots$ & IIR & 3.34 & 1.51 \\
\hline $\begin{array}{l}\text { Disseminate information on in- } \\
\text { justice of justice system ..... }\end{array}$ & IIR & 4.26 & 1.34 \\
\hline
\end{tabular}

There was slight agreement with statements dealing with organizing within the agency (organize other workers, $\bar{x}=3.13$; reform agency, $\bar{x}=3.34$ ). This shows an unwillingness of workers to engage in activities which affect social institutions, but this energy for reform can be "safely" utilized in changing the agency. The responses to these statements show clearly an unwillingness to engage in activities toward societal change.

Factor 4: Agency Constraints. Most workers tended to agree with the statement that workers should bend agency policies 
TABLE XXXVI

AGENCY CONSTRAINTS

\begin{tabular}{cccc}
\hline Item & $\begin{array}{l}\text { Hypothesized } \\
\text { Category }\end{array}$ & $\begin{array}{l}\text { Mean } \\
\text { Responses }\end{array}$ & $\begin{array}{c}\text { Standard } \\
\text { Deviation }\end{array}$ \\
\hline Stay within agency guidelines ... & IC & 4.49 & 1.33 \\
"Bend" agency policies ....... & IIR & 3.70 & 1.43 \\
\hline
\end{tabular}

if necessary to help their clients. They disagreed with the statement that workers should stay within agency guidelines. Again, this indicates energy for reform within the agency, but not in society.

$$
\text { TABLE XXXVII }
$$

RETURN TO OLD VALUES

\begin{tabular}{|c|c|c|c|}
\hline Item & $\begin{array}{l}\text { Hypothesized } \\
\text { Category }\end{array}$ & $\begin{array}{l}\text { Mean } \\
\text { Responses }\end{array}$ & $\begin{array}{l}\text { Standard } \\
\text { Deviation }\end{array}$ \\
\hline $\begin{array}{l}\text { Stress traditional values of } \\
\quad \text { family solidarity .......... }\end{array}$ & IIC & 4.49 & 1.33 \\
\hline $\begin{array}{l}\text { Stress "old" values since they } \\
\text { represent the backbone of } \\
\text { society } \ldots \ldots \ldots \ldots \ldots \ldots \ldots \ldots\end{array}$ & IIC & 4.73 & 1.19 \\
\hline
\end{tabular}

Factor 5: Return to Old Values. There was consistent agreement with the statement of stressing family solidarity $(\bar{x}=3.58)$. However, there was disagreement with stressing the old values of 
society $(\bar{x}=4.73)$. This is a confusing trend and perhaps indicates some confusion with this statement about old values.

TABLE XXXVIII

COMMUNITY INVOLVEMENT

\begin{tabular}{|c|c|c|c|}
\hline Item & $\begin{array}{l}\text { Hypothesized } \\
\text { Category }\end{array}$ & $\begin{array}{l}\text { Mean } \\
\text { Responses }\end{array}$ & $\begin{array}{l}\text { Standard } \\
\text { Deviation }\end{array}$ \\
\hline $\begin{array}{l}\text { Speak to leaders of the com- } \\
\text { munity about their responsi- } \\
\text { bility in the solution of } \\
\text { delinquency } \ldots \ldots \ldots \ldots \ldots \ldots\end{array}$ & IIL & 2.61 & 1.00 \\
\hline $\begin{array}{l}\text { Talk with business people about } \\
\text { the role of business in helping } \\
\text { delinquents } \ldots \ldots \ldots \ldots \ldots \ldots\end{array}$ & IIL & 3.34 & 1.22 \\
\hline $\begin{array}{l}\text { Develop job opportunities for } \\
\quad \text { youth } \ldots \ldots \ldots \ldots \ldots \ldots \ldots \ldots\end{array}$ & IIL & 2.87 & 1.16 \\
\hline Develop community resources... & IIL & 2.88 & 1.35 \\
\hline $\begin{array}{l}\text { Advocacy techniques should be } \\
\text { used extensively ............ }\end{array}$ & IIL & 2.59 & 1.29 \\
\hline Link clients to organizations ..... & IIL & 2.74 & 1.30 \\
\hline
\end{tabular}

Factor 6: Community Involvement. This factor shows a strong pattern of agreement with activities in the community and developing job opportunities (average mean $=3.0$ ). The role of the worker is stressed as linking clients with organizations, developing job opportunities for youth and talking with the business community about their roles in helping youth. Again, this validates a consictent 
pattern of agreement with activities involving organizations and individuals in the community.

\section{SUMMARY OF FINDINGS}

The overall findings of our study tend to support the research done by Longres and Wyers (1976) on the Administrators of Delinquency Intervention programs. As in the previous research, our sample tended to be overwhelmingly oriented towards theories stressing the personal deficiency perspective. The respondents generally regarded delinquency to be caused by a psychological impairment and not the result of a social structure problem. The goal of delinquency programs should be to integrate the individual back into the existing system, but not to change the system. The role of the worker should be that of a counselor, therapist, broker of services; but not to engage in systemic social changes. Our findings indicate that the workers, at best, are incrementalists in their attitudes.

It must also be pointed out that in the present analysis, there are subcategories that are not sufficiently developed. There appears to be no Paradigm I Radical in the "Causes" of delinquency. Also, there is a weak relationship of Paradigm I Radical categories in the "Programs" and "Roles." It appears that the Paradigm I Radical category exists only in the "Roles" - raising the consciousness of 
youth. Therefore, these categories are deleted in the revised questionnaire.

\section{FEEDBACK FROM RESPONDENTS}

It is important in conducting a study to know how the instrument used was perceived by the respondents. Several respondents provided written feedback on their questionnaires. Some of the comments dealt with the complexity and generality of various questions. While some were in agreement with only part of the statement, others felt several phrases should have been operationally defined (i.e., "delinquency programs," "gainful dignified employment," "treatment," "old values"). In other cases, many respondents qualified their answers. The most frequent comment was, "Depending on the situation." Furthermore, several members of the sample felt the need to modify statements so as to make them consistent with their personal beliefs.

Though there was no feedback given on the specific issues studied, the various criticisms of the questionnaire are useful in designing future studies in this area.

\section{DEVELOPMENT OF A NEW QUESTIONNAIRE}

A revised questionnaire is enclosed in the Appendix of this study in expectation that the new instrument will lead to a further 
refining of the theoretical framework.

The questions included in the new instrument are those that had the highest factor loadings and reflected most closely the hypothetical categories in their respective factors.

The advantages of the revised instrument are that it has been pre-tested and validated, and that it asks highly focused questions. 


\section{CHAPTER V}

\section{SUMMARY AND RECOMMENDATIONS}

This study was undertaken as a result of our interest in the field of juvenile delinquency. The purpose of the research was to examine the attitudes of line workers concerning their perceptions of the causes of delinquency, the programs of delinquency prevention, and their role as juvenile workers. In addition, we felt a need to conduct research in this area where little has been done.

Chapter II presents a review of the relevant literature in our field of study. Although numerous studies have been conducted, it was found that there is no conclusive perspective on the cause of juvenile delinquency. Family relationships, socio-economic factors, low self-esteem, labeling, and other concepts may be considered as factors in causation. Also, there has been little agreement on delinquency prevention programs. It is necessary to develop rosearch methodologies which will provide more accurate evaluative information about prevention programs. An attempt was made to relate the delinquency causation and intervention theories to our theoretical framework.

Our theoretical framework was based on the models of 
Warren's constructs of the personal problem orientation, Paradigm I, and dysfunctional social structure orientation, Paradigm II. We further elaborated the two Paradigms to include the Conservative, Liberal, and Radical categories.

The questionnaire was developed to reflect these categories. It was hypothesized that the sample's attitudes would fit into our categories. It was administered to a sample of 101 line workers. The resulting data was then coded and a factor analysis conducted.

\section{SUMMARY OF DATA}

In general, the analysis of the factors validated our hypothosized categories. In the three sections of our questionnaire, the causes, the programs, the roles of the worker, there was a clear distinction between Paradigm I and Paradigm II concepts. In several factors, however, there was not clear discrimination between the categories of Conservative, Liberal, and Radical. For our purposes, Conservative was defined as a "return to traditional values of society," a Liberal as "individual change, and Radical as "social institutional change."

The sample tended to strongly agree with Liberal items especially those emphasizing the family in causation of delinquency and the method of family therapy as a desired intervention strategy. There was also agreement with some significant statements which 
emphasized dysfunctions in organizations as causes of delinquency. It was emphasized that the worker should involve herself/himself with the se organizations in order to reduce the incidence of delinquency.

There was also a strong trend towards statements stressing a need to "return to old values"|- especially tighter family control. The sample did show disagreement with those statements emphasizing hereditary factors as causative of delinquency.

Overall, there was disagreement with statements emphasizing the present social structure as causative of delinquency.

\section{Recommendations}

The present research focused on the development of a questionnaire that would measure the hypothesized categories. Also, generalizations about the responses of our sample of 101 . line workers were made.

It is apparent from the data, that there continues to be an overall emphasis on the situation-centered Paradigm I approach with a particular emphasis on the family. There was a trend towards agreement with some Paradigm II Liberal statements which stressed working with community organizations which affect youth.

There does seem to be a trend among contemporary line workers to examine some environmental influences that might be 
causative of delinquency and to begin to address these influences. There is a reluctance among our sample to look at broad institutional causation factors or to work towards social change. There 'was, however, agreement that organizations should be modified and agency rules "bent" if necessary to benefit youths.

This research adds to the developing body of knowledge about workers' attitudes and can be used for further educational efforts. Future research could focus on comparisons of groups of workers related to places of employment and educational achievement. This would generate data about what factors are most important in developing a worker's attitude.

With the validation of this questionnaire and our development of a revised one, further research could be easily conducted on a larger random sample with good, viable results. 


\section{BIBLIOGRAPHY}

Bailey, Roy and Mike Brake, Eds. Radical Social Work (New York: Pantheon Books, 1975).

Ball, John and Nell Logan. "Early Sexual Behavior of Lower-Class Delinquent Girls, " Journal of Criminal Law, Criminology and Police Science, 51(July-August, 1960):201-214.

Bohlke, Robert. "Social Mobility, Stratification, Inconsistency, and Middle-Class Juvenile Delinquency," in Edmund Vaz, ed., Middle-Class Juvenile Delinquency (New York: Harper \& Row, 1967).

Bordua, David. "Some Comments on Theories of Group Delinquency," Sociological Inquiry, 32(Spring, 1962):249-256.

Braeutigan, Bonnie, Charlotte Wellman, Carol Arden, and Dennis Schilling. Specialized Out-of-Home Care Project, practicum (Portland State University, School of Social Work, I976).

Chesney-Lind, Meda. "Juvenile Delinquency: The Sexualization of Female Crime," Psychology Today, 8(July, 1974): 43-46.

City Club of Portland. Report on Juvenile Justice System in Multnomah County, 57:23 (November, 1976).

Clarke, Steven. "Juvenile Offender Programs and Delinquency Prevention," Crime and Delinquency Literature, 6:3 (September, 1974).

Cloward, Richard and Lloyd Ohlin. Delinquency and Opportunity, (New York: The Free Press, 1960).

Cohen, Albert K. Delinquent Boys (New York: The Free Press, 1955).

Cohen, Albert K. "Middle-Class Delinquency and the Social Structure, " in Edmund Vaz, ed., Middle-Class Juvenile Delinquency, (New York: Harper \& Row, 1967). 
Cohen, Albert K. "Social Control and Subcultural Change," Youth and Society, 3:3 (March, 1972): 259-276.

Comrey, Andrew L. A First Course in Factor Analysis (Los Angeles, Academic Press, 1973).

Empy, LaMar T., and Steven Lubeck. Delinquency Prevention Strategies (Washington, D. C.: U.S. Government Printing Office, 1970).

Empy, LaMar, and Maynard Erickson. "Hidden Delinquency and Social Status," Social Forces, 44 (June, 1965-1966): 546-554.

England, Ralph. "A Theory of Middle-Class Delinquency," in Edmund Vaz, ed., Middle-Class Juvenile Delinquency (New York: Harper \& Row, 1967).

Flacks, Richard. Youth and Social Change (Chicago: Markham Co., 1971).

Geis, Gilbert. Juvenile Gangs (Washington, D.C.: U.S. Government Printing Office, June, 1965).

Gemigname, Robert J. "Youth Service System," Federal Probation, 36 (December, 1972): 48-53.

Gibbons, Don. Delinquent Behavior (Englewood Cliffs, New Jersey: Prentice-Hall, 1975).

Gibbs, Jack. "Conceptions of Deviant Behavior, The Old and The New," Pacific Sociological Review, 9(1966): 9-14.

Glueck, Sheldon and Eleanor. Physique and Behavior (New York: Harper \& Row, 1956).

Gordon, David M. "Class and the Economics of Crime," Review of Radical Political Economics, 1971.

Grossbard, Hyman. "Ego Deficiency in Delinquents," Social Casework, 43:4 (April, 1962): 171-179.

Hirschi, Travis. Causes of Juvenile Delinquency (Berkeley: University of California Press, 1961). 
Hussmann, Trudy. Social Workers Attitudes About Poverty (Portland, Oregon, 1976).

James, Dorothy. "Reflection of American Values in Attitudes and Procedures of the Profession," Poverty, Politics and Change (Englewood Cliffs, N.J.: Prentice-Hall, 1972): 72-103.

Jesness, Carl. The Jesness Inventory, 35 (Sacramento, California: 1963).

Kelly, Delos H., and William Pink. "School Commitment, Youth Rebellion, and Delinquency, "Criminology, 10 (February, 1973): $473-486$.

Kitsuse, John. "Summary Statements of Labeling Theory, Societal Reactions to Deviant Behavior: Problem of Theory and Methods," Pacific Sociological Review, 9(1963): 246-256.

Kitsuse, John, and William Dietrick. "Delinquent Boys: A Critique," American Sociological Review, 24 (April, 1959): 208-215.

Kittrie, Nicholas. The Right to be Different (Maryland: John Hopkins Press, 1971).

Klapmuts, Nora. "Diversion From the Justice System," Crime and Delinquency Literature (March, 1974): 108-131.

Knight, Douglas. Delinquency Causes and Remedies (California Youth Authority: Division of Research and Development, 1972).

Kvaraceus, William, and Walter Miller. Delinquent Behavior, Culture and the Individual (Washington, D.C., National Educational Association of U.S., 1959).

Kvaraceus, William, and Walter Miller. "Norm Violating Behavior in Middle-Class Culture," in Edmund Vaz, ed., Middle-Class Juvenile Delinquency (New York: Harper \& Row, 1967).

Lemert, Edwin. Human Deviance, Social Problems and Sucial Contract (Englewood Cliffs, New Jersey: Prentice-Hall, 1967).

Lemert, Edwin. Instead of Court-Diversion in Juvenile Justice (Maryland: National Institute of Mental Health, 1971). 
Logan, Charles. "Evaluative Research in Crime and Delinquency A Reappraisal," The Journal of Criminal Law, Criminology and Police Science, 3(1972): 380.

Longres, John and Norman Wyers. Towards the Future of Delinquency Programs: The Thinking of Administrators (National Criminal Justice Education Development Project, 1976).

Martin, John. "Three Approaches to Delinquency Prevention," Crime and Delinquency, 7:1 (January, 1961).

Matza, David. Delinquency and Drift (New York: John Wiley and Sons, 1964).

Mech, Edmund. Delinquency Prevention: A Program Review of Intervention Approaches (Portland, Oregon: Regional Research Institute for Human Services, 1975).

Mechanic, David. Mental Health and Social Policy (Englewood Cliffs, New Jersey: Prentice-Hall, 1969).

Merton, Robert. "Social Structure and Anomie," in Harwin Voss, ed. , Society, Delinquency, and Delinquent Behavior (Boston: Little, Brown, and Co., 1970).

Merton, Robert. Social Theory and Social Structure (Glencoe, Illinois: The Free Press, 1957).

Miller, Walter. "Lower Class Culture as a Generating Milieu of Group Delinquency," The Journal of Social Issues, 14(1958): $5-19$.

Mills, C. Wright. "The Professional Ideology of Social Pathologists," in Irving Horowitz, ed., Power, Politics, and People (New York: Ballatine Books, 1968).

National Institute of Mental Health. Government Based Correctional Programs-Models and Practice (Maryland, U.S. Government Printing Office, 1971).

Nye, F. Ivan. Family Relations and Delinquency (New York: John Wiley and Sons, 1958). 
Perlman, Richard I. "Antisocial Behavior of the Minor in the U.S.," in Harwin Voss, ed., Society, Delinquency, and Delinquent Behavior (Boston: Little, Brown, and Co., 1970).

Pine, Gerald. "Social Class, Social Mobility, and Delinquent Behavior," The Personnel and Guidance Journal, 43 (April, 1965): 770-774.

Pink, William, and Marvin F. White. Delinquency Prevention: A Conference Perspective on Issues and Directions (Portland, Oregon: Regional Research Institute on Youth Development and Delinquency Prevention, 1973).

Quinney, Richard. "Crime, Delinquency, and Social Areas, " Journal of Research in Crime and Delinquency, I (July, 1964).

Ruby, Cheryl. Theoretical Orientation of Diversion Staff (University of Oregon, Ph.D. Dissertation, 1974).

Ryan, William. Blaming the Victim (New York: Vintage Books, 1971).

Schildernick, J.H.F. Factor Analysis Applied (Netherlands, Rotterdam Press, 1969).

Schur, Edwin M. Labeling Deviant Behaviox (New York: Harper \& Row, 1971).

Schur, Edwin M. Radical Non-Intervention, Rethinking the Delinquency Problem (Englewood Cliffs, New Jersey: PrenticeHall, 1973).

Scott, Joseph and Edmund Vaz. "A Perspective on Middle-Class Delinquency," in Edmund Vaz, ed., Middle-Class Juvenile Delinquency (New York: Harper \& Row, 1967).

Short, James, and Ivan Nye. "Extent of Unrecorded Juvenile Delinquency: Tentative Conclusions," Journal of Criminal Law, Criminology, and Political Science, 49 (November-December, 1958): 296-302.

Sieverdes, Christopher. "Differential Disposition of Juvenile Offenders: A Study of Juvenile Court Labeling, "Crime and Delinquency Literature, 6:1 (March, 1954): 15-17. 
Sutherland, Edwin, and Donald Cresy. in Harwin Voss, ed., Society, Delinquency, and Delinquent Behavior (Boston: Little and Brown Co., 1970).

Tannenbaum, Frank. Crime and the Community (New York: Columbia University Press, 1938).

Task Force Report. Juvenile Delinquency and Crime (Washington, D. C.: U.S. Government Printing Office, 1967).

Thorne, Gaylord; Roland Thorpe; and Ralph Wetzel. "Behavior Modification Techniques: New Tools for Probation Officers," Federal Probation, 31:2 (June, 1967).

Toby, Jackson, and Larry Karacki. "The Uncommitted Adolescent: Candidate for Gang Socialization," Sociological Inquiry, Vol. 32, Spring, 1962.

U.S. Department of Justice. Uniform Crime Report for the U.S. (Washington, D.C.: U.S. Government Printing Office, 1976): 177 .

Warren, Roland. "The Sociology of Knowledge and the Problems of the Inner Cities, "Social Science Quarterly, 52:3 (December, 1971): 469-492.

Wheeler, Stanley, and Leonard Cottrell. Juvenile Delinguency, Its Prevention and Control (New York: Russell Sage Foundation, 1966): $22-27$.

Williams, Jay, and Martin Gold. "From Delinquent Behavior to Official Delinquency," Social Problems, 20 (Fall, 1972): 209-229. 
ON THE CAUSES OF DELINQUENCY, ITS ERADICATION, AND THE ROLE OF THE WORKER

\section{Respondent's Personal Background:}

1. Sex

2. Age

3. Academic Degree (Name and Level)

4. Where Obtained

5. When completed

6. Father's Occupation

7. Father's Educational Attainment

8. Size of Community in which you spent your childhood and adolescence.

$$
\begin{aligned}
& 15,000 \text { and under } \\
& 15,000-50,000 \\
& 50,000-100,000 \\
& 100,000-500,000 \\
& 500,000 \text { and over }
\end{aligned}
$$

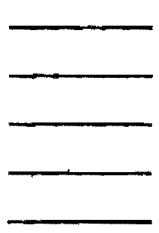

9. Geographical area in which you spent your childhood and adolescence.

West

East South Midwest

10. How would you describe your philosophical perspective?

Conservative

Liberal

Radical 
11. Number of clients on your present caseload.

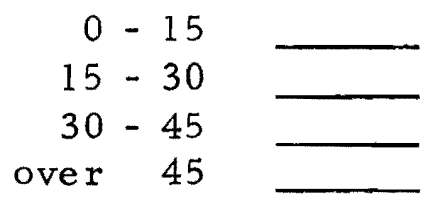

12. Level of satisfaction with current job.

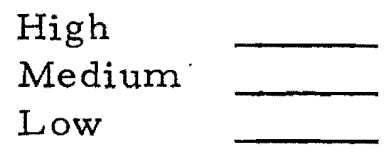

Although we want to know something about your personal background, we are also very interested in your attitudes and beliefs about youth, and especially about delinquent youth. In paricular, we are interested in your own personal views about the causes of delinquency, and the types of programs needed to prevent delinquency, also the kinds of services which should be given to youth.

Let's take each of these one by one.

On the following pages is a series of statements related to the causes of delinquency. They are accompanied by an attitude scale ranging from 1 through 7 . The statements are intended to measure how much adjudicated delinquent behavior is at least partially explained by the statement. Notice that a one (1) means that you feel that you strongly agree with the statement, while a seven (7) means that you strongly disagree. Read each statement and then select which number best describes your position. Please circle your choice.

\section{THE CAUSES OF DELINQUENCY}

1. Biological factors such as brain abnormalities and chromosonal peculiarities play an important part in causing delinquency.

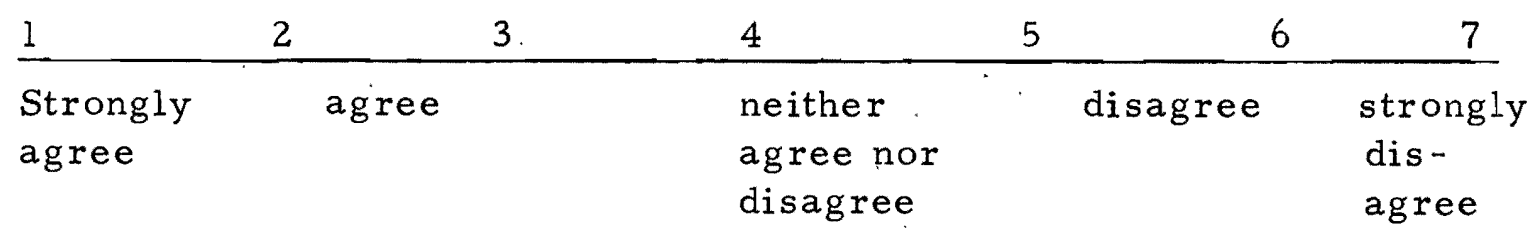


2. Innate agression, if not channeled in a constructive way, is likely to manifest itself in delinquent behavior.

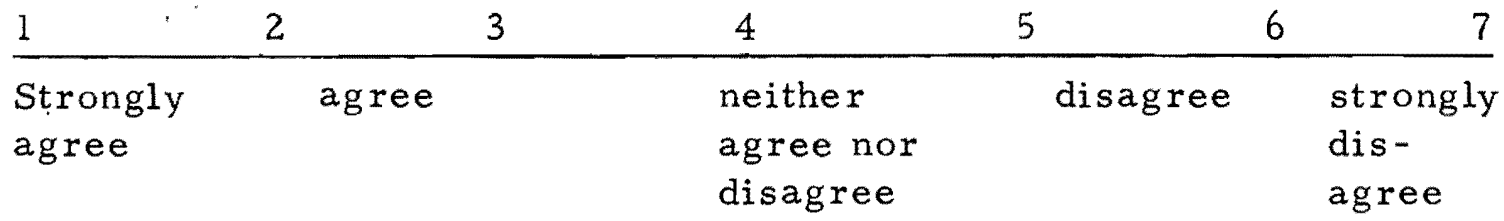

3. Youth who are given a lot of free time are more likely to engage in delinquent behavior than those kept occupied.

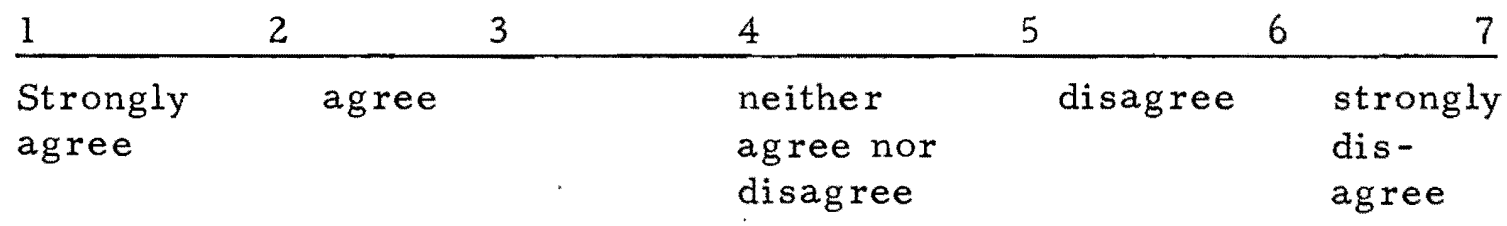

4. Lower innate intelligence is an important factor in understanding delinquent behavior.

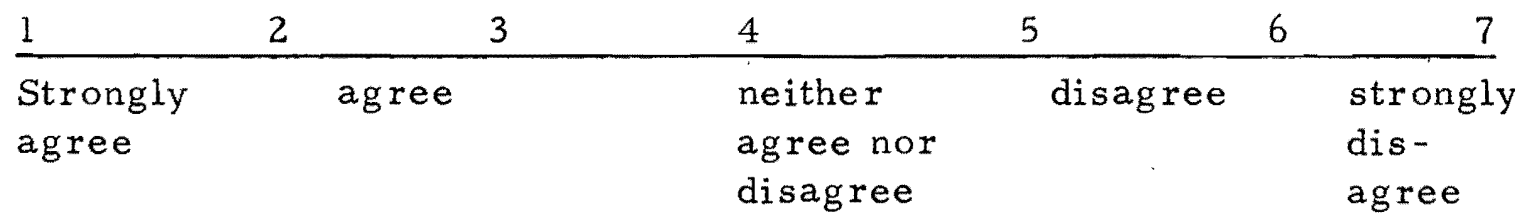

5. A lack of firm parental discipline is an important factor in generating delinquency.

\begin{tabular}{lllllll}
1 & 2 & 3 & 4 & 5 & 6 & 7 \\
\hline $\begin{array}{l}\text { Strongly } \\
\text { agree }\end{array}$ & agree & & neither & disagree & strongly \\
& & agree nor & & dis - \\
& & & & agree
\end{tabular}

6. A poor sense of morality leads to delinquent behavior.

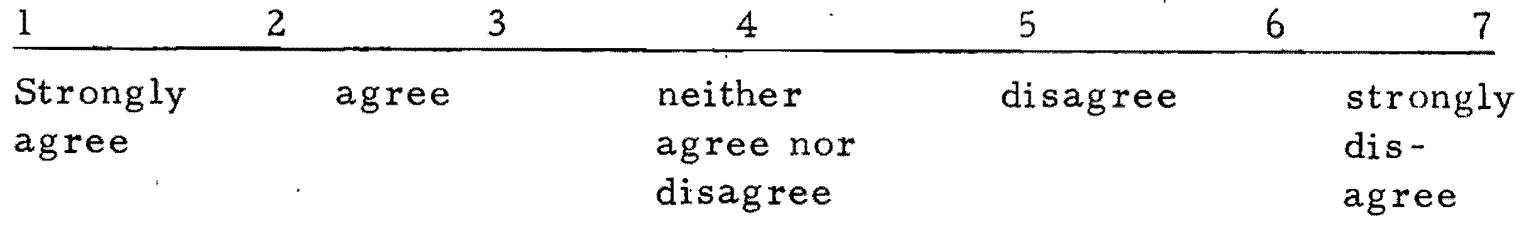


7. Poorly formed super-egos is a frequent cause of delinquency.

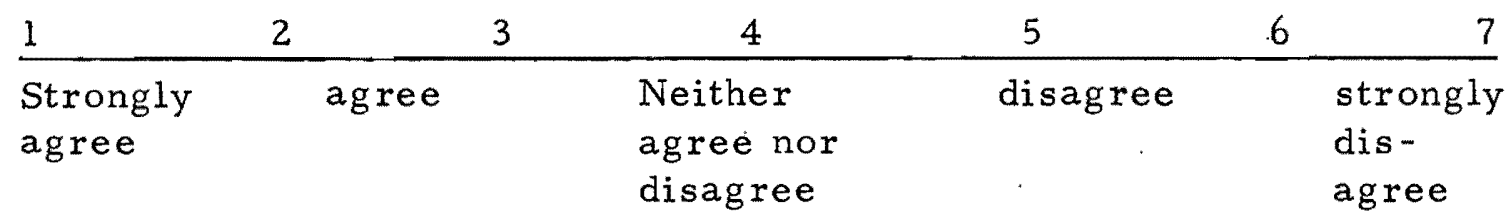

8. The breakdown of traditional family and social values is an important reason for the rise in juvenile delinquency.

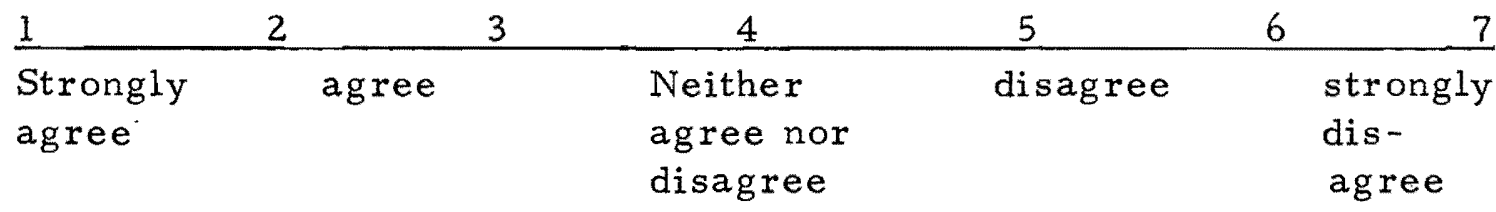

9. Too much questioning of social institutions among the young has led to increased delinquency.

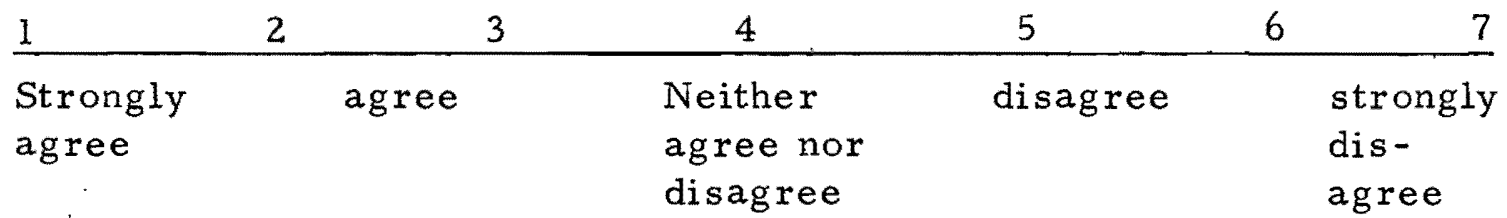

10. A morally permissive society sets the stage for delinquency.

\begin{tabular}{|c|c|c|c|c|c|c|}
\hline 1 & 2 & 3 & 4 & 5 & 6 & 7 \\
\hline $\begin{array}{l}\text { Strongly } \\
\text { agree }\end{array}$ & & agree & $\begin{array}{l}\text { Neither } \\
\text { agree nor } \\
\text { disagree }\end{array}$ & disagree & & $\begin{array}{l}\text { strongly } \\
\text { dis- } \\
\text { agree }\end{array}$ \\
\hline
\end{tabular}

11. The schools help to create delinquency through negative and somewhat arbitrary labeling of certain youth.

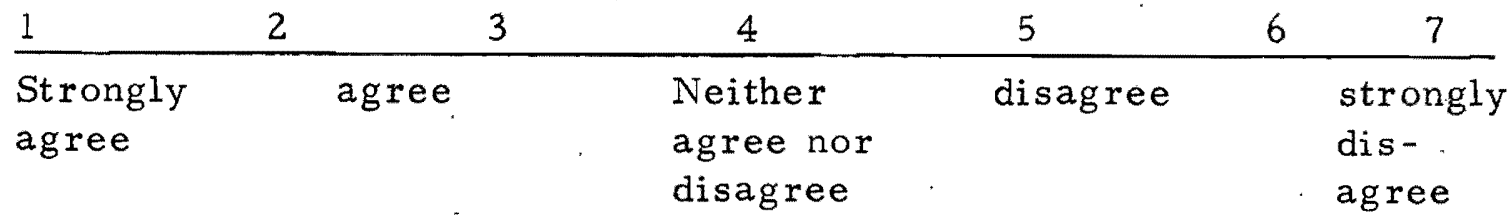


12. If a society doesn't teach the need to achieve and the need for personal responsibility it creates the environment necessary for delinquency.

$\begin{array}{lllllll}1 & 2 & 3 & 4 & 5 & 6 & 7 \\ \begin{array}{l}\text { Strongly } \\ \text { agree }\end{array} & \text { agree } & & \begin{array}{l}\text { Neither } \\ \text { agree nor } \\ \text { disagree }\end{array} & \text { disagree } & & \begin{array}{l}\text { strongly } \\ \text { dis - } \\ \text { agree }\end{array}\end{array}$

13. Delinquency is caused by a breakdown in community relations including dysfunctional schools and neighborhoods.

$\begin{array}{lllllll}1 & 2 & 3 & 4 & 5 & 6 & 7 \\ \begin{array}{l}\text { Strongly } \\ \text { agree }\end{array} & \text { agree } & & \begin{array}{l}\text { Neither } \\ \text { agree nor } \\ \text { disagree }\end{array} & \text { disagree } & \begin{array}{l}\text { strongly } \\ \text { dis - } \\ \text { agree }\end{array}\end{array}$

14. The values of ethnic and racial groups frequently predispose youth to delinquency.

$\begin{array}{lllllll}1 & 2 & 3 & 4 & 5 & 6 & 7 \\ \begin{array}{l}\text { Strongly } \\ \text { agree }\end{array} & \text { agree } & & \begin{array}{l}\text { Neither } \\ \text { agree nor } \\ \text { disagree }\end{array} & \text { disagree } & \begin{array}{l}\text { strongly } \\ \text { dis - } \\ \text { agree }\end{array}\end{array}$

15. A youth's immediate environment, especially poor family relationships and negative peer influences, are important in causing delinquent behavior.

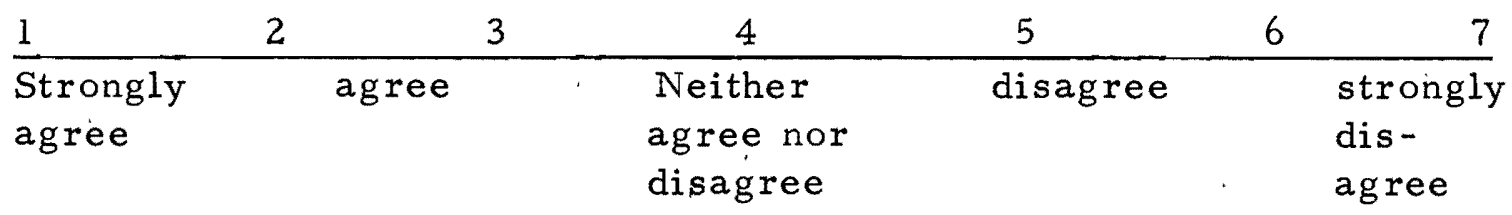

16. Psychological problems of youth such as a poor self-image and difficulties with self-identity are important in causing delinquency.

\begin{tabular}{lllllll}
1 & 2 & 3 & 4 & 5 & 6 & 7 \\
\hline $\begin{array}{llll}\text { Strongly } \\
\text { agree }\end{array}$ & agree & & $\begin{array}{l}\text { Neither } \\
\text { agree nor } \\
\text { disagree }\end{array}$ & disagree & & $\begin{array}{l}\text { strongly } \\
\text { dis - } \\
\text { agree }\end{array}$
\end{tabular}


17. Youth who lack employable skills are more likely to become delinquent.

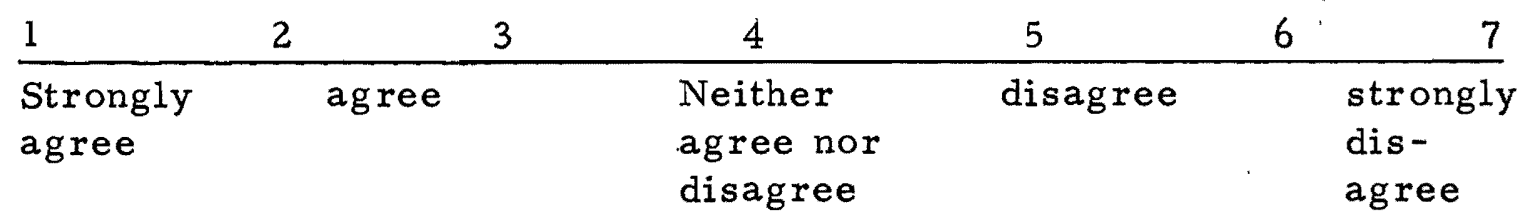

18. Peer group pressure frequently causes delinquent behavior.

$\begin{array}{llllll}1 & 2 & 3 & 4 & 5 & 6 \\ \begin{array}{l}\text { Strongly } \\ \text { agree }\end{array} & \text { agree } & & \begin{array}{l}\text { Neither } \\ \text { agree nor } \\ \text { disagree }\end{array} & \text { disagree } & \begin{array}{l}\text { strongly } \\ \text { dis - } \\ \text { agree }\end{array}\end{array}$

19. Delinquency results from unstable, dysfunctional family environment.

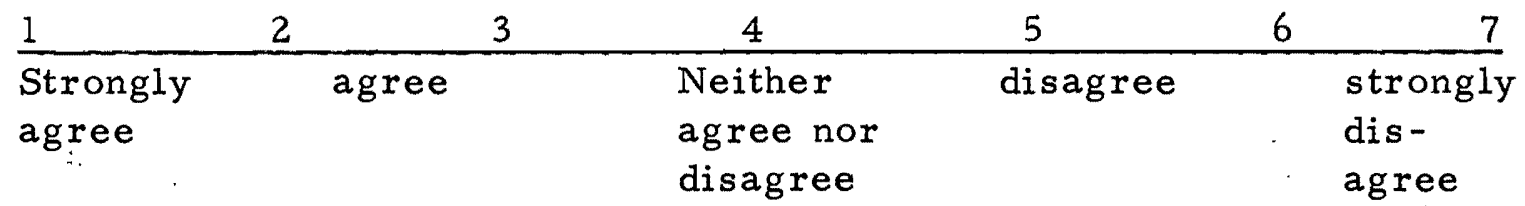

20. The lack of good parenting skills on the part of parents inadvertently leads children into delinquency patterns.

$\begin{array}{lllllll}1 & 2 & 3 & 4 & 5 & 6 & 7 \\ \begin{array}{llll}\text { Strongly } \\ \text { agree }\end{array} & \text { agree } & & \begin{array}{l}\text { Neither } \\ \text { agree nor } \\ \text { disagree }\end{array} & \text { disagree } & \text { strongly } \\ & & & & \begin{array}{l}\text { dis - } \\ \text { agree }\end{array}\end{array}$

21. Poor communication between the family and the schools often generates delinquent behavior.

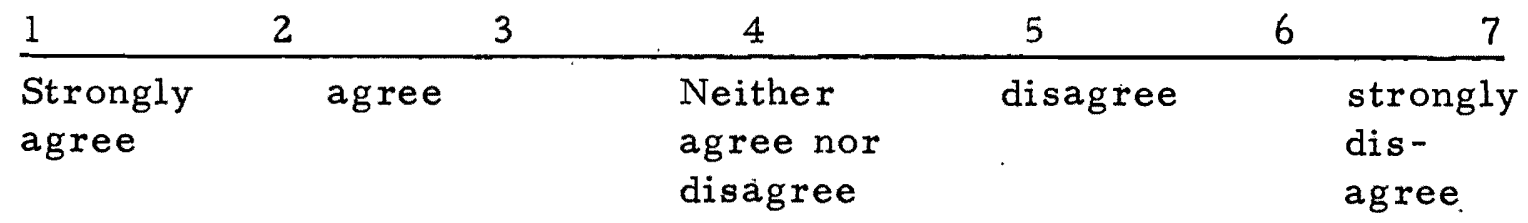


22. Our society provides few meaningful roles for youth, the reby increasing the potential for delinquency.

$\begin{array}{lllllll}1 & 2 & 3 & 4 & 5 & 6 & 7 \\ \begin{array}{l}\text { Strongly } \\ \text { agree }\end{array} & \text { agree } & \begin{array}{l}\text { Neither } \\ \text { agree nor } \\ \text { disagree }\end{array} & \text { disagree } & \begin{array}{l}\text { strongly } \\ \text { dis - } \\ \text { agree }\end{array}\end{array}$

23. The size, complexity and impersonality of most public schools inadvertently fosters delinquency.

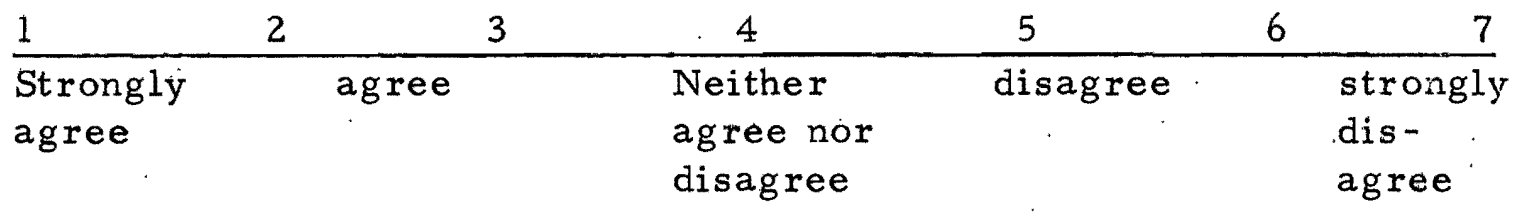

24. A lack of job opportunities for youth is important in generating delinquency.

$\begin{array}{lllllll}1 & 2 & 3 & 4 & 5 & 6 & 7 \\ \begin{array}{l}\text { Strongly } \\ \text { agree }\end{array} & \text { agree } & \begin{array}{l}\text { Neither } \\ \text { agree nor } \\ \text { disagree }\end{array} & \text { disagree } & \begin{array}{l}\text { strongly } \\ \text { dis - } \\ \text { agree }\end{array}\end{array}$

25. The police and the juvenile justice system frequently create delinquents instead of preventing delinquency.

$\begin{array}{lllllll}1 & 2 & 3 & 4 & 5 & 6 & 7 \\ \begin{array}{l}\text { Strongly } \\ \text { agree }\end{array} & \text { agree } & \begin{array}{l}\text { Neither } \\ \text { agree nor } \\ \text { disagree }\end{array} & \text { disagree } & \begin{array}{l}\text { strongly } \\ \text { dis }- \\ \text { agree }\end{array}\end{array}$

26. The causes of delinquency are ultimately to be found in the competitive norms and values of our economic institutions.

$\begin{array}{lllllll}1 & 2 & 3 & 4 & 5 & 6 & 7 \\ \begin{array}{l}\text { Strongly } \\ \text { agree }\end{array} & \text { agree } & \ddots & \begin{array}{l}\text { Neither } \\ \text { agree nor } \\ \text { disagree }\end{array} & \text { disagree } & \begin{array}{l}\text { strongly } \\ \text { dis- } \\ \text { agree }\end{array}\end{array}$


27. Inadequate communication among family members often creates the negative home environment which in turn leads to delinquent behavior.

$\begin{array}{lllllll}1 & 2 & 3 & 4 & 5 & 6 & 7 \\ \begin{array}{l}\begin{array}{l}\text { Strongly } \\ \text { agree }\end{array} \\ \text { agree }\end{array} & \begin{array}{l}\text { Neither } \\ \text { agree nor } \\ \text { disagree }\end{array} & \text { disagree } & \begin{array}{l}\text { strongly } \\ \text { dis - } \\ \text { agree }\end{array}\end{array}$

28. Delinquent youth frequently lack the ability to control anti-social impulses.

\begin{tabular}{|c|c|c|c|c|c|}
\hline 1 & 2 & 4 & 5 & 6 & $\quad 7$ \\
\hline $\begin{array}{l}\text { Strongly } \\
\text { agree }\end{array}$ & agree & $\begin{array}{l}\text { Neither } \\
\text { agree nor } \\
\text { disagree }\end{array}$ & disagree & & $\begin{array}{l}\text { strongly } \\
\text { dis- } \\
\text { agree }\end{array}$ \\
\hline
\end{tabular}

29. Juvenile delinquency reflects alienated youth striking back at an unjust system.

$\begin{array}{lllllll}1 & 2 & 3 & 4 & 5 & 6 & 7 \\ \begin{array}{l}\text { Strongly } \\ \text { agree }\end{array} & \text { agree } & \begin{array}{l}\text { Neither } \\ \text { agree nor } \\ \text { disagree }\end{array} & \text { disagree } & \begin{array}{l}\text { strongly } \\ \text { dis - } \\ \text { agree }\end{array}\end{array}$

30. There are no real psychological differences between delinquent and non-delinquent youth.

\begin{tabular}{|c|c|c|c|c|c|c|}
\hline 1 & 2 & 3 & 4 & 5 & 6 & 7 \\
\hline $\begin{array}{l}\text { Strongly } \\
\text { agree }\end{array}$ & & & $\begin{array}{l}\text { Neither } \\
\text { agree nor } \\
\text { disagree }\end{array}$ & disagree & & $\begin{array}{l}\text { strongly } \\
\text { dis- } \\
\text { agree }\end{array}$ \\
\hline
\end{tabular}

31. Delinquency represents learned behaviors, learned through inadequate family socialization.

\begin{tabular}{|c|c|c|c|c|c|c|}
\hline 1 & 2 & 3 & 4 & 5 & 6 & 7 \\
\hline $\begin{array}{l}\text { Strongly } \\
\text { agree }\end{array}$ & & & $\begin{array}{l}\text { Neither } \\
\text { agree nor } \\
\text { disagree }\end{array}$ & disagree & & $\begin{array}{l}\text { strongly } \\
\text { dis - } \\
\text { agree }\end{array}$ \\
\hline
\end{tabular}


32. In many wàys, delinquency reflects healthy youth making us aware of problems in our social system.

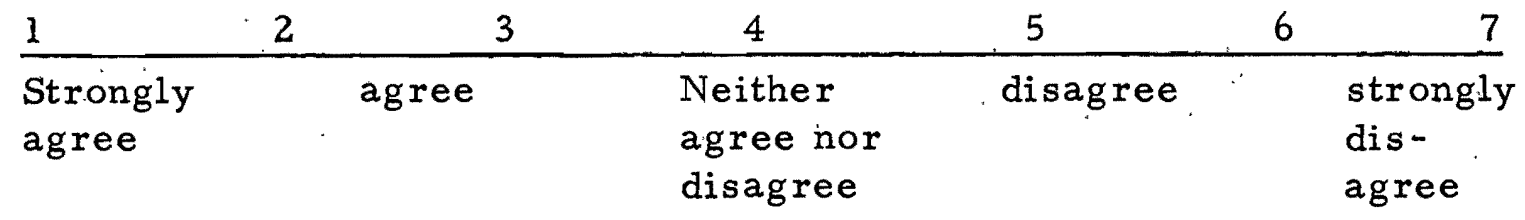

33. Until a social system can provide gainful dignified employment we can always expect delinquency.

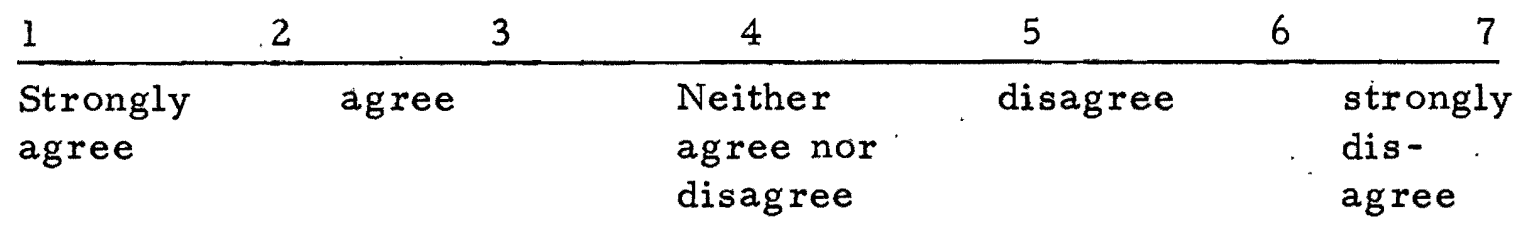

34. To the extent that capitalism can not function without a poverty or near poverty class it contributes importantly to the creation of delinquency.

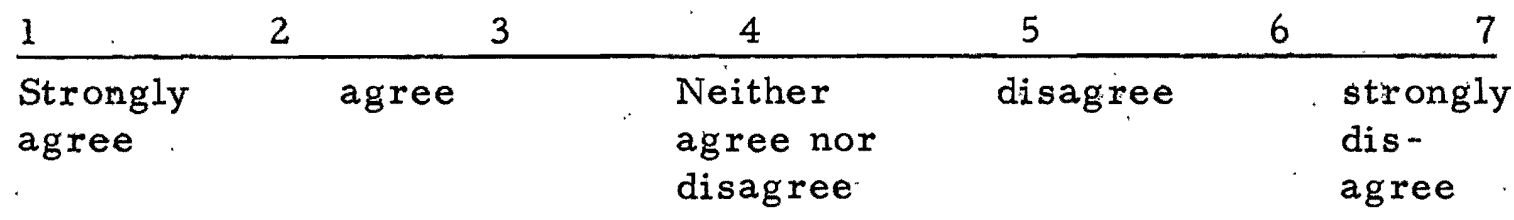

\section{Part II}

Here is another attitude scale. Note that a one (1) on this scale means that you strongly agree with the statement, while a seven (7) means that you strongly oppose the statement.

\section{PROGRAM AND POLICY CONSIDERATIONS}

1. In general, delinquency services have failed to demonstrate their effectiveness in ameliorating delinquency.

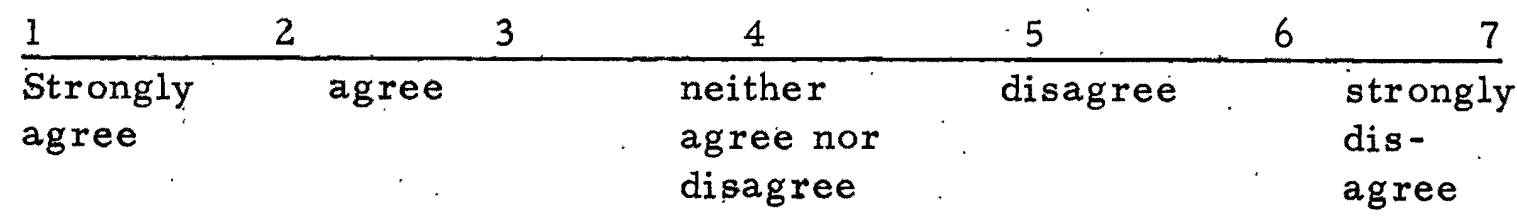


2. Delinquency programs have helped many youth back on the road to adult maturity.

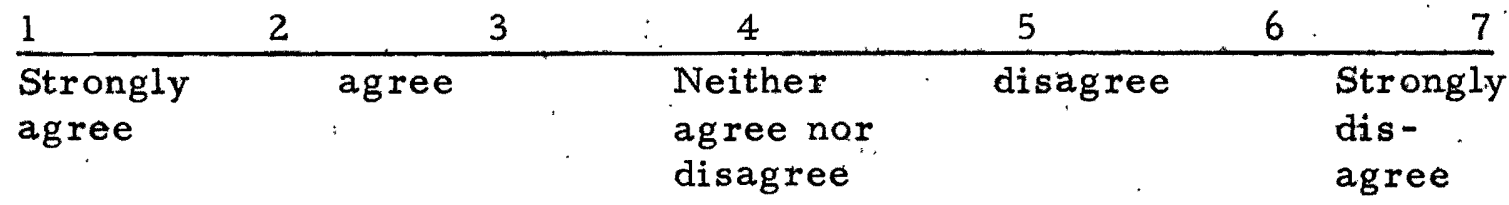

3. When delinquency programs fail, bureaucratic problems such as high caseloads, red tape, or excessive paper work are usually to blame.

\begin{tabular}{|c|c|c|c|c|c|c|}
\hline 1 & 2 & 3 & 4 & 5 & 6 & 7 \\
\hline $\begin{array}{l}\text { Strongly } \\
\text { agree }\end{array}$ & & agree & $\begin{array}{l}\text { Neither } \\
\text { agree nor } \\
\text { disagree }\end{array}$ & disagree & & $\begin{array}{l}\text { Strongly } \\
\text { dis - } \\
\text { agree }\end{array}$ \\
\hline
\end{tabular}

4. It is unlikely that any youth service can really eliminate delinquency.

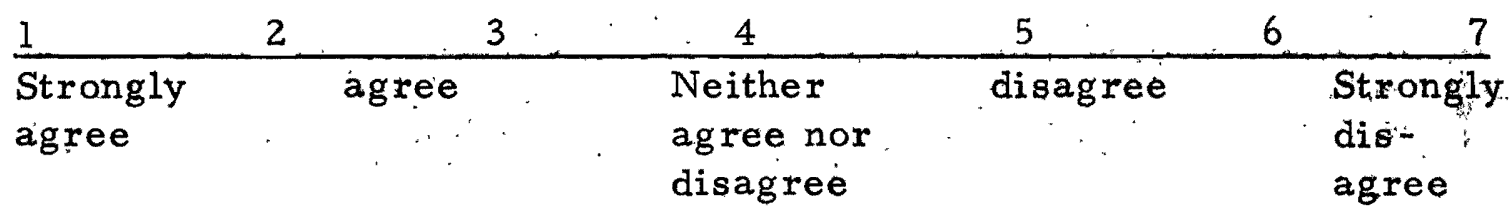

5. When delinquency programs fail, it is an indication that we need to improve counseling and casework techniques.

\begin{tabular}{|c|c|c|c|c|c|c|}
\hline 1 & 2 & 3 & 4 & 5 & 6 & 7 \\
\hline $\begin{array}{l}\text { Strongly } \\
\text { agree }\end{array}$ & & & $\begin{array}{l}\text { Neither } \\
\text { agree nor } \\
\text { disagree }\end{array}$ & disagree & & $\begin{array}{l}\text { Strongly } \\
\text { dis- } \\
\text { agree }\end{array}$ \\
\hline
\end{tabular}

6. When delinquency programs fail it is usually because there is a lack of community resources to help youth and their families overcome their problems.

$\begin{array}{llllll}1 & 3 & 4 & 5 & 6 & 7 \\ \begin{array}{l}\text { Strongly } \\ \text { agree }\end{array} & \text { agree } & \begin{array}{l}\text { Neither } \\ \text { sgree nor } \\ \text { disagree }\end{array} & \text { disagree } & \begin{array}{l}\text { Strongly } \\ \text { dis } \\ \text { agree }\end{array}\end{array}$


7. When delinquency programs fail it is because they fail to take into account and mitigate against the societal roots of delinquency.

\begin{tabular}{lllllll}
1 & 2 & 3 & \multicolumn{1}{c}{4} & 5 & 6 & 7 \\
\hline $\begin{array}{l}\text { Strongly } \\
\text { agree }\end{array}$ & agree & $\begin{array}{l}\text { Neither } \\
\text { agree nor } \\
\text { disagree }\end{array}$ & disagree & $\begin{array}{l}\text { Strongly } \\
\text { dis - } \\
\text { agree }\end{array}$
\end{tabular}

8. Providing effective services for youth is severely limited by the poor communication which exists among agencies providing juvenile services.

\begin{tabular}{|c|c|c|c|c|c|c|}
\hline 1 & 2 & 3 & 4 & 5 & 6 & 7 \\
\hline $\begin{array}{l}\text { Strongly } \\
\text { agree }\end{array}$ & & & $\begin{array}{l}\text { Neither } \\
\text { agree nor } \\
\text { disagree }\end{array}$ & disagree & & $\begin{array}{l}\text { Strongly } \\
\text { dis - } \\
\text { agree }\end{array}$ \\
\hline
\end{tabular}

9. The heart of a delinquency program is good individual and family casework or counseling.

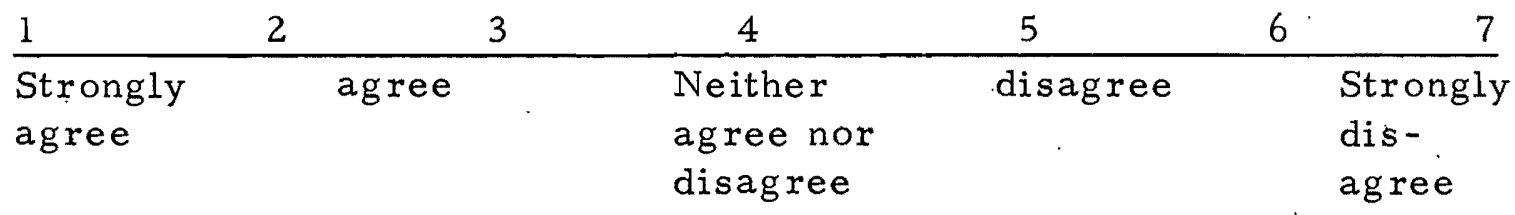

10. The traditional values of family life should be supported by social service programs.

\begin{tabular}{|c|c|c|c|c|c|c|}
\hline 1 & 2 & 3 & 4 & 5 & 6 & 7 \\
\hline $\begin{array}{l}\text { Strongly } \\
\text { agree }\end{array}$ & & & $\begin{array}{l}\text { Neither } \\
\text { agree nor } \\
\text { disagree }\end{array}$ & disagree & & $\begin{array}{l}\text { Strongly } \\
\text { dis - } \\
\text { agree }\end{array}$ \\
\hline
\end{tabular}

11. Programs that employ "compulsory treatment" should be eliminated.

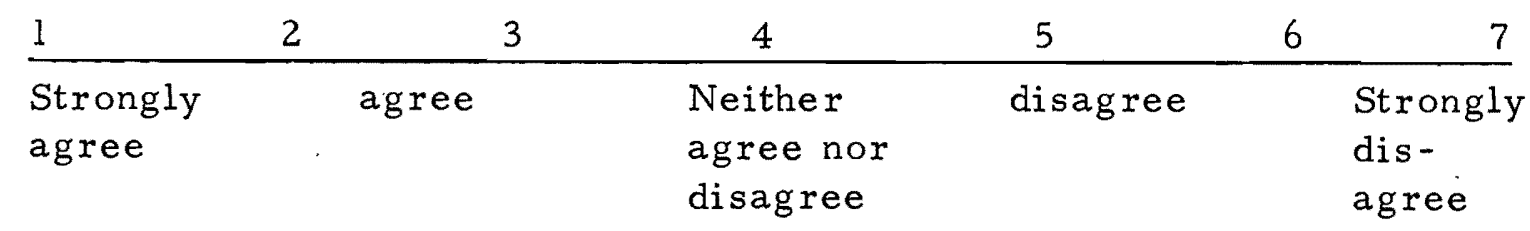


12. Delinquency programs should aim to educate the public about the societal conditions negating the ability of youth to reach their full potential.

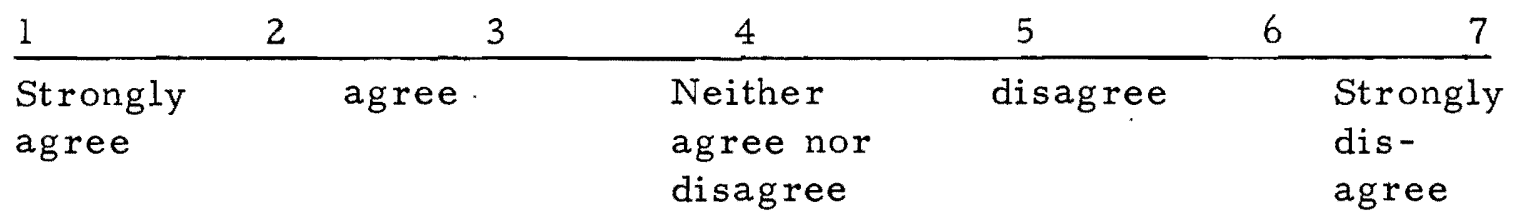

13. In order to make a large dent in the delinquency problem, we should apply family counseling and therapy techniques in order to stimulate an improved home environment.

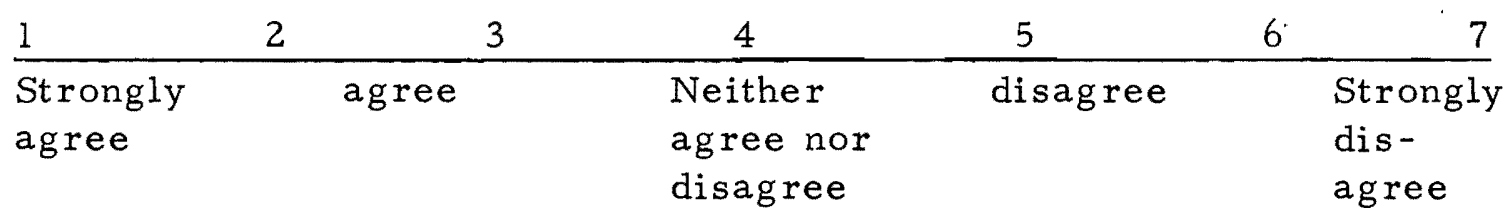

14. Programs should be designed to encourage the business community to increase employment opportunities for youth.

$\begin{array}{llllll}1 & 2 & 3 & 4 & 5 & 6 \\ \begin{array}{l}\text { Strongly } \\ \text { agree }\end{array} & \text { agree } & \begin{array}{l}\text { Neither } \\ \text { agree nor } \\ \text { disagree }\end{array} & \text { disagree } & \begin{array}{l}\text { Strongly } \\ \text { dis - } \\ \text { agree }\end{array}\end{array}$

15. Youth would best be served if programs attempted to create meaningful work and educational opportunities for them.

$\begin{array}{lrrllll}1 & 2 & 3 & 4 & 5 & 6 & 7 \\ \begin{array}{l}\text { Strongly } \\ \text { agree }\end{array} & \text { agree } & \begin{array}{l}\text { Neither } \\ \text { agree nor } \\ \text { disagree }\end{array} & \text { disagree } & \begin{array}{l}\text { Strongly } \\ \text { dis - } \\ \text { agree }\end{array}\end{array}$

16. In order to make a large dent in the delinquency problem, we . should apply psychological counseling and therapy techniques to individual youth.

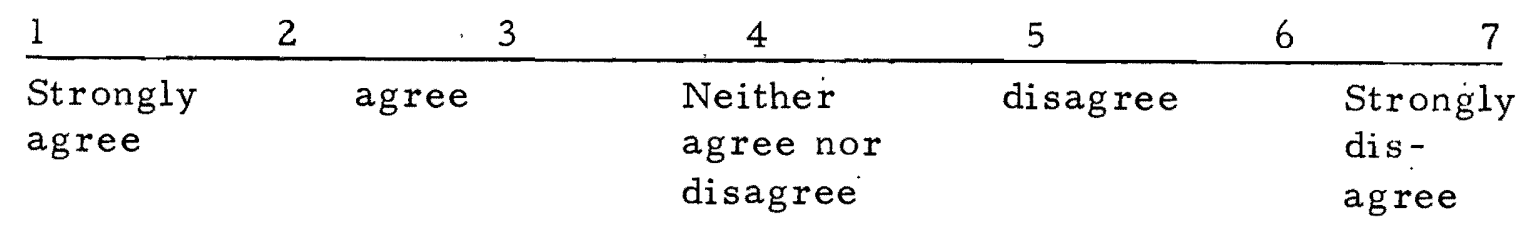


17. To a considerable extent, delinquents would be best served if policies were adopted that accepted greater diversity in youth behavior and narrowed exceedingly special delinquency law.

\begin{tabular}{|c|c|c|c|c|c|c|}
\hline 1 & 2 & 3 & 4 & 5 & 6 & 7 \\
\hline $\begin{array}{l}\text { Strongly } \\
\text { agree }\end{array}$ & & & $\begin{array}{l}\text { Neither } \\
\text { agree nor } \\
\text { disagree }\end{array}$ & disagree & & $\begin{array}{l}\text { Strongly } \\
\text { dis - } \\
\text { agree }\end{array}$ \\
\hline
\end{tabular}

18. Programs for youth should be designed to improve their interpersonal skills for communicating and getting along with others.

\begin{tabular}{|c|c|c|c|c|c|c|}
\hline 1 & 2 & 3 & 4 & 5 & 6 & 7 \\
\hline $\begin{array}{l}\text { Strongly } \\
\text { agree }\end{array}$ & & & $\begin{array}{l}\text { Neither } \\
\text { agree nor } \\
\text { disagree }\end{array}$ & disagree & & $\begin{array}{l}\text { Strongly } \\
\text { dis- } \\
\text { agree }\end{array}$ \\
\hline
\end{tabular}

19. Programs should address the breakdown in socializing influences by involving the whole community in the fight against delinquency.

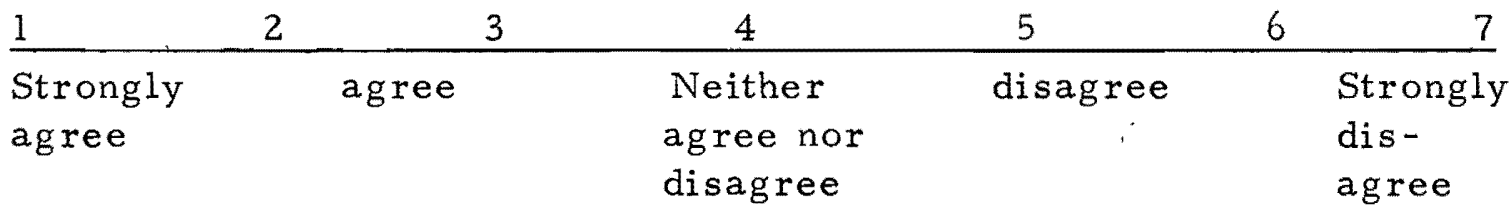

20. Delinquency programs should aim to educate the public about the psychological needs of youth.

\begin{tabular}{lllllll}
1 & 2 & 3 & 4 & 5 & 6 & 7 \\
\hline $\begin{array}{l}\text { Strongly } \\
\text { agree }\end{array}$ & agree & & $\begin{array}{l}\text { Neither } \\
\text { agree nor } \\
\text { disagree }\end{array}$ & disagree & & Strongly \\
& & & & dis - \\
agree
\end{tabular}

21. Delinquent youth are best served by programs that stress practical methods for competing in the work world.

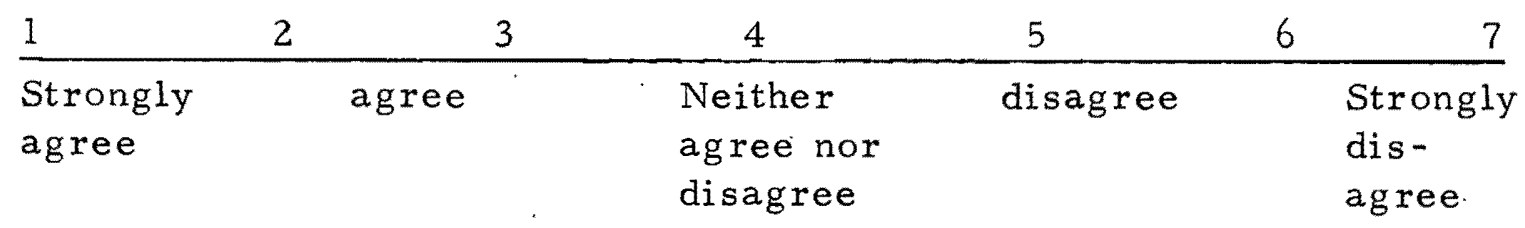


22. Although we should try to help all youth many are so set in their ways that little can be done to change them.

\begin{tabular}{lllllll}
1 & 2 & 3 & 4 & 5 & 6 & 7 \\
\hline $\begin{array}{llll}\text { Strongly } \\
\text { agree }\end{array}$ & agree & & Neither & disagree & & Strongly \\
& & & $\begin{array}{l}\text { agree nor } \\
\text { disagree }\end{array}$ & & dis - \\
& & & & agree
\end{tabular}

23. Conduct illegal only for a minor should be eliminated from juvenile court jurisdictions.

\begin{tabular}{|c|c|c|c|c|c|c|}
\hline 1 & 2 & 3 & 4 & 5 & 6 & 7 \\
\hline $\begin{array}{l}\text { Strongly } \\
\text { agree }\end{array}$ & & agree & $\begin{array}{l}\text { Neither } \\
\text { agree nor } \\
\text { disagree }\end{array}$ & disagree & & $\begin{array}{l}\text { Strongly } \\
\text { dis- } \\
\text { agree }\end{array}$ \\
\hline
\end{tabular}

24. Youth programs should work closely with the schools, especially for the early detection of potentially delinquent children.

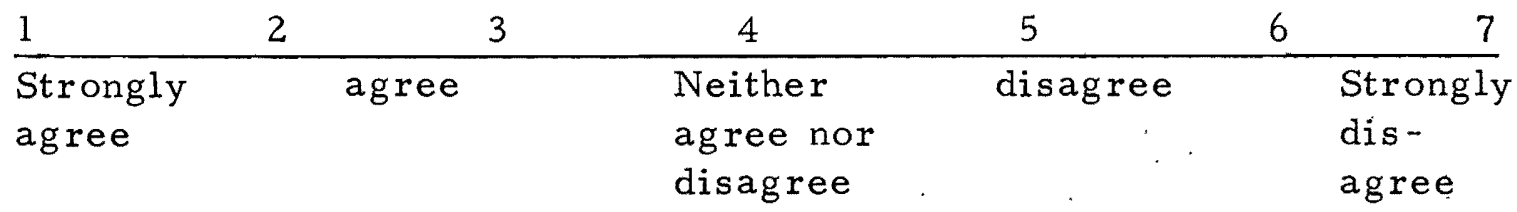

25. Programs for delinquents should provide the means to assure youth social status within the community.

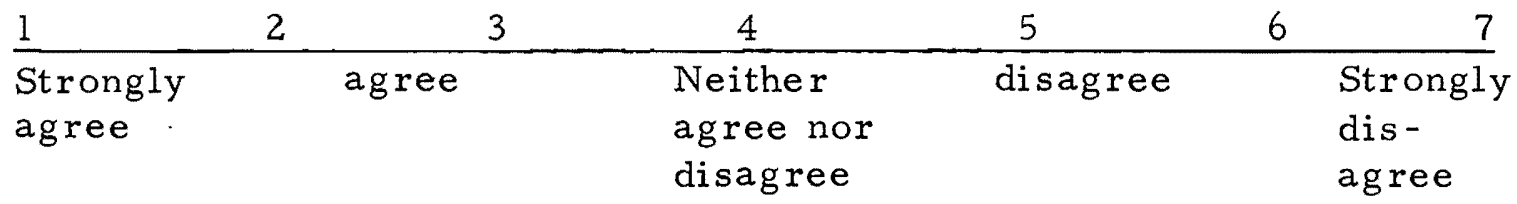

26. Youth programs should work closely with the schools to make them more receptive to the needs of youth and their families.

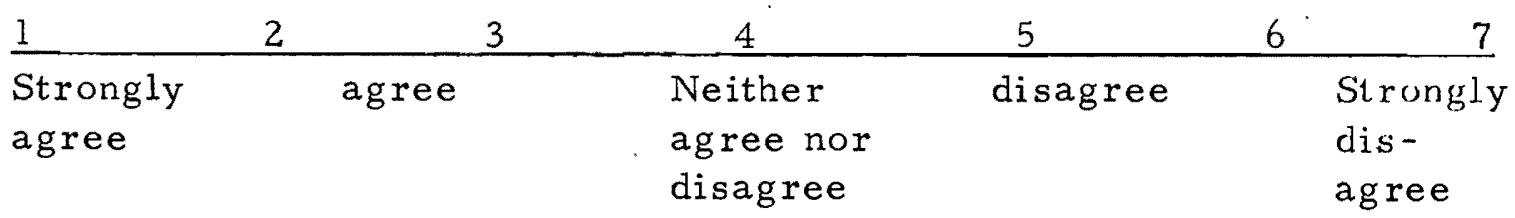


27. Every child should have the right to refuse treatment.

\begin{tabular}{lllllll}
1 & 2 & 3 & 4 & 5 & 6 & 7 \\
\hline $\begin{array}{l}\text { Strongly } \\
\text { agree }\end{array}$ & agree & & Neither & disagree & & Strongly \\
& & & agree nor \\
disagree & & & dis - \\
& & & & agree
\end{tabular}

28. Schools should be encouraged to develop alternative education programs.

\begin{tabular}{lllllll}
1 & 2 & 3 & 4 & 5 & 6 & 7 \\
\hline $\begin{array}{llll}\text { Strongly } \\
\text { agree }\end{array}$ & agree & & Neither & disagree & & Strongly \\
& & & agree nor & & & dis - \\
& & & & agree
\end{tabular}

29. Removing a delinquent child from a poor home environment will result in decreased delinquency.

\begin{tabular}{lllllll}
1 & 2 & 3 & 4 & 5 & 6 & 7 \\
\hline $\begin{array}{l}\text { Strongly } \\
\text { agree }\end{array}$ & agree & & Neither & disagree & & Strongly \\
& & & agree nor & & & dis - \\
& & & & agree:
\end{tabular}

30. Programs for youth should assure that the youth they serve have policy input.

$\begin{array}{llllll}1 & 2 & 3 & 4 & 5 & 6\end{array}$

31. Programs for youth should aim to be supportive of the emotional needs of youth.

$\begin{array}{lllllll}1 & 2 & 3 & 4 & 5 & 6 & 7 \\ \begin{array}{l}\text { Strongly } \\ \text { agree }\end{array} & \text { agree } & & \begin{array}{l}\text { Neither } \\ \text { agree nor } \\ \text { disagree }\end{array} & \text { disagree } & \text { Strongly } \\ & & & & \text { dis - } \\ & & & & \text { agree. }\end{array}$


32. Social service programs should stimulate better family functioning by helping promote better communication and better parenting skills.

\begin{tabular}{lllllll}
1 & 2 & 3 & 4 & 5 & 6 & 7 \\
\hline $\begin{array}{llll}\text { Strongly } \\
\text { agree }\end{array}$ & agree & & Neither & disagree & & Strongly \\
& & & $\begin{array}{l}\text { agree nor } \\
\text { disagree }\end{array}$ & & dis - \\
& & & & & agree
\end{tabular}

33. Counseling programs which help youth gain a greater critical understanding of our society would best serve the needs of youth.

\begin{tabular}{lllllll}
1 & 2 & 3 & 4 & 5 & 6 & 7 \\
\hline $\begin{array}{llll}\text { Strongly } \\
\text { agree }\end{array}$ & agree & & Neither & disagree & & Strongly \\
& & & $\begin{array}{l}\text { agree nor } \\
\text { disagree }\end{array}$ & & dis - \\
& & & & agree
\end{tabular}

\section{$\underline{\text { Part III }}$}

Please continue as before. Remember that a one (1) means that you strongly agree with a statement, and a seven (7) that you strongly disagree.

\section{ROLE OF THE WORKER}

1. The principal efforts of youth workers should be to help delinquents gain psychological, growth-producing insights into the causes of their misconduct.

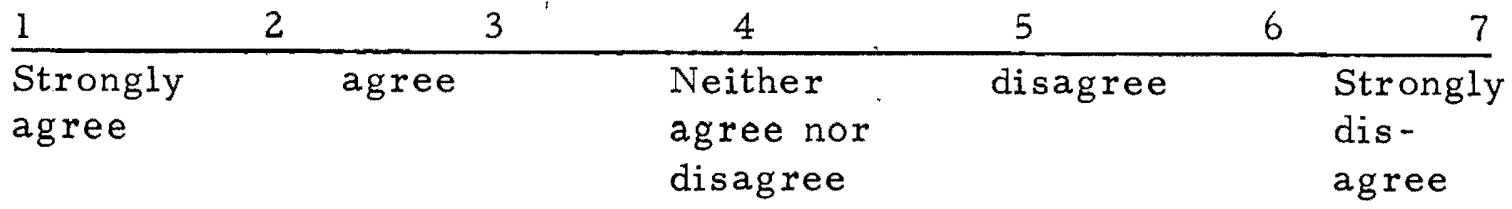


2. Youth workers would best help delinquents by involving themselves wholeheartedly in legitimate political activities aimed at producing a more equitable society.

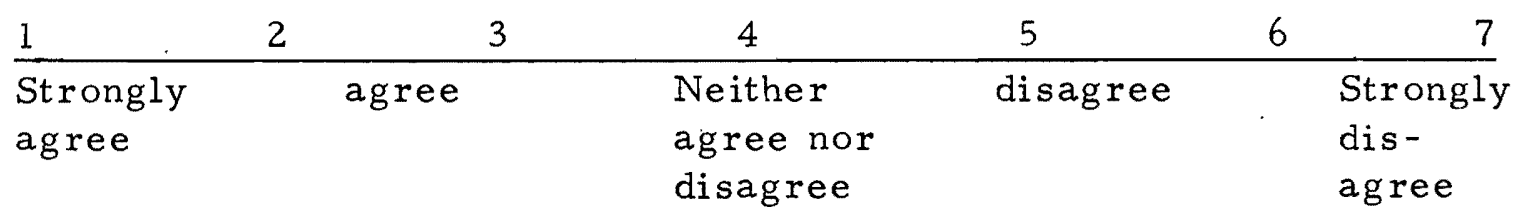

3. One important role dimension is to obtain the assistance of offenders'families, relatives, and friends so that they can help the offender to refrain from further delinquent behavior.

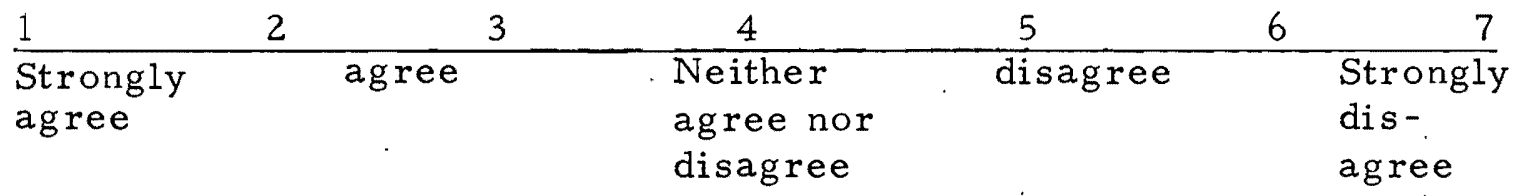

4. Self-responsibility is an important goal for workers to stress to their clients.

$\begin{array}{lllllll}1 & 2 & 3 & 4 & 5 & 6 & . \cdot 7 \\ \begin{array}{llll}\text { Strongly } \\ \text { agree }\end{array} & \text { agree } & & \begin{array}{l}\text { Neither } \\ \text { agree nor } \\ \text { disagree }\end{array} & \text { disagree } & \text { Strongly } \\ & & & & \begin{array}{l}\text { dis - } \\ \text { agree }\end{array}\end{array}$

5. Workers should speak to the leaders of the community who might be of service to the offender, for community leadership has a responsibility in the solution of youth delinquency.

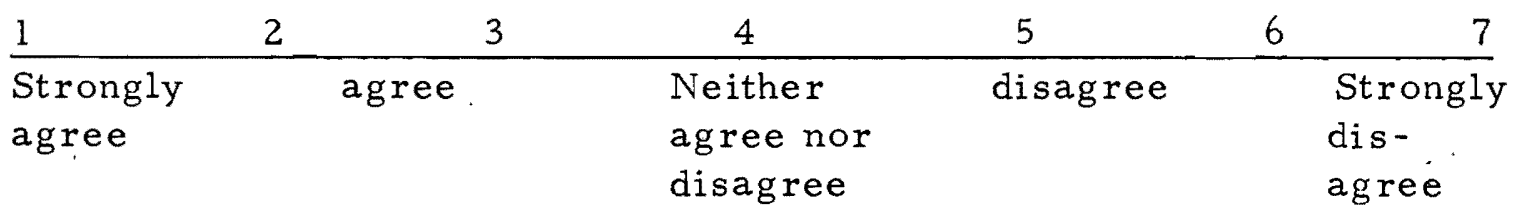

6. Workers should stress the traditional values of family solidarity and responsibility since much delinquent behavior is a function of the breakdown of the se values.

$\begin{array}{lllllll}1 & 2 & 3 & 4 & 5 & 6 & 7 \\ \begin{array}{l}\text { Strongly } \\ \text { agree }\end{array} & \text { agree } & & \begin{array}{l}\text { Neither } \\ \text { agree nor } \\ \text { disagree }\end{array} & \text { disagree } & \begin{array}{l}\text { Strongly } \\ \text { dis - } \\ \text { agree }\end{array}\end{array}$


7. Any worker should feel free to organize other workers around the issue of understanding the rights of offenders and be prepared to advocate the fulfillment of those rights.

\begin{tabular}{|c|c|c|c|c|c|c|}
\hline 1 & 2 & 3 & 4 & 5 & 6 & 7 \\
\hline $\begin{array}{l}\text { Strongly } \\
\text { agree }\end{array}$ & & & $\begin{array}{l}\text { Neither } \\
\text { agree nor } \\
\text { disagree }\end{array}$ & disagree & & $\begin{array}{l}\text { Strongly } \\
\text { dis - } \\
\text { agree }\end{array}$ \\
\hline
\end{tabular}

8. Workers should help offenders to understand that their misconduct is not the result of neurosis and bad mental health, but rather a function of blocked opportunity.

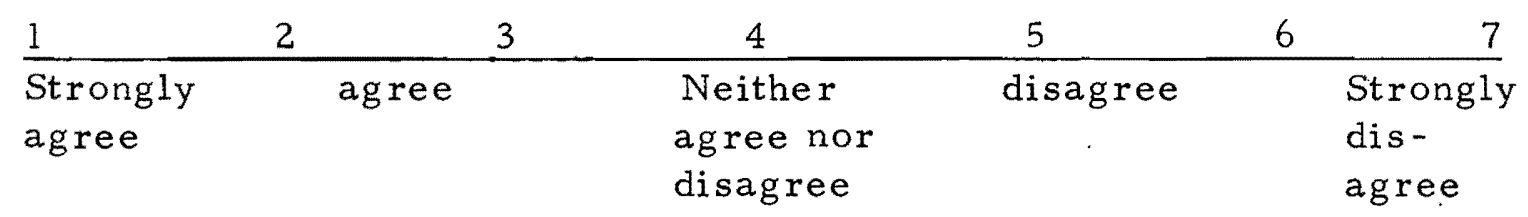

9. Workers need to include probationary rules in their dealings with offenders, since the structures and limits they introduce are important motivators for non-delinquent behavior.

$\begin{array}{llllll}1 & 2 & 3 & 4 & 5 & 6 \\ \begin{array}{l}\text { Strongly } \\ \text { agree }\end{array} & \text { agree } & \begin{array}{l}\text { Neither } \\ \text { agree nor } \\ \text { disagree }\end{array} & \text { disagree } & \begin{array}{l}\text { Strongly } \\ \text { dis - } \\ \text { agree }\end{array}\end{array}$

10. Workers should always stay within agency guidelines since they were developed in the best interests of youth.

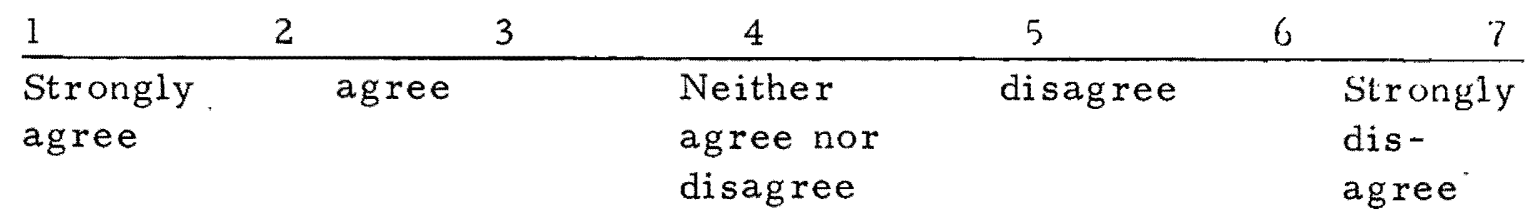

11. Workers have a responsibility to talk with business people about the role of business in helping delinquents.

$\begin{array}{lllllll}1 & 2 & 3 & 4 & 5 & 6 & 7 \\ \begin{array}{l}\text { Strongly } \\ \text { agree }\end{array} & \text { agree } & & \begin{array}{l}\text { Neither } \\ \text { agree nor } \\ \text { disagree }\end{array} & \text { disagree } & \begin{array}{l}\text { Strongly } \\ \text { dis - } \\ \text { agree }\end{array}\end{array}$


12. A major task of youth workers should be to reform their agency so that it is more responsive to youth.

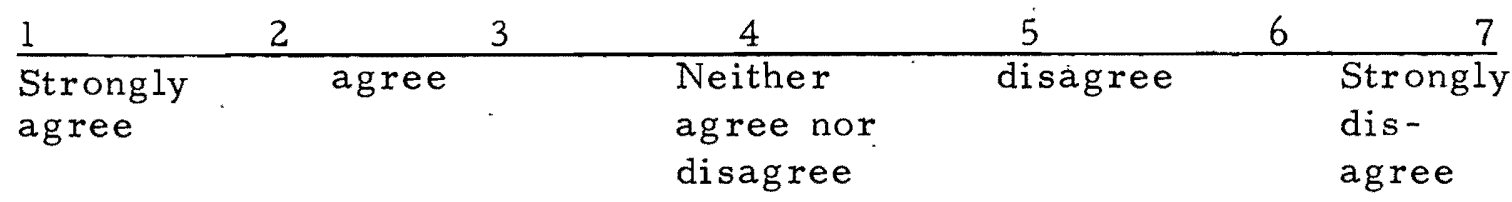

13. It is important that workers involve the families of youth in service programs in order to strengthen the family systems.

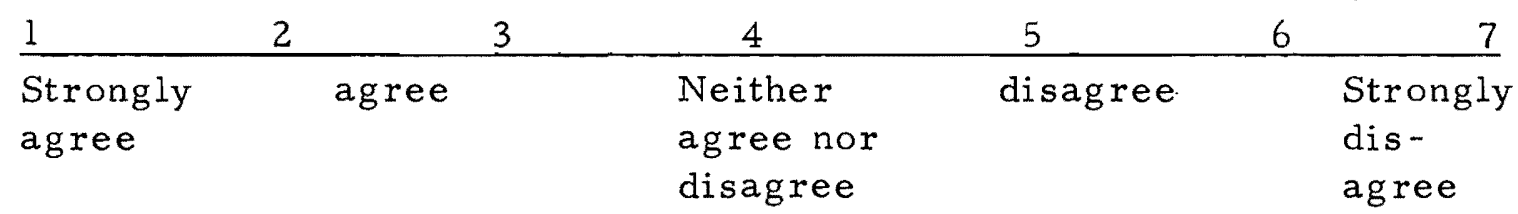

14. Youth workers should develop group counseling skills.

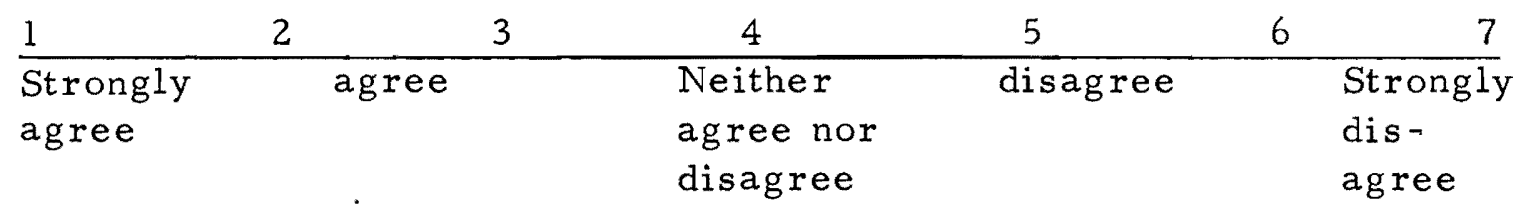

15. Workers should devote considerable attention to the development of job opportunities for delinquent youth.

\begin{tabular}{|c|c|c|c|c|c|c|}
\hline 1 & 2 & 3 & 4 & 5 & 6 & 7 \\
\hline $\begin{array}{l}\text { Strongly } \\
\text { agree }\end{array}$ & & & $\begin{array}{l}\text { Neither } \\
\text { agree nor } \\
\text { disagree }\end{array}$ & disagree & & $\begin{array}{l}\text { Strongly } \\
\text { dis- } \\
\text { agree }\end{array}$ \\
\hline
\end{tabular}

16. Effective workers should stress the "old" values, since such values still represent the backbone of this society.

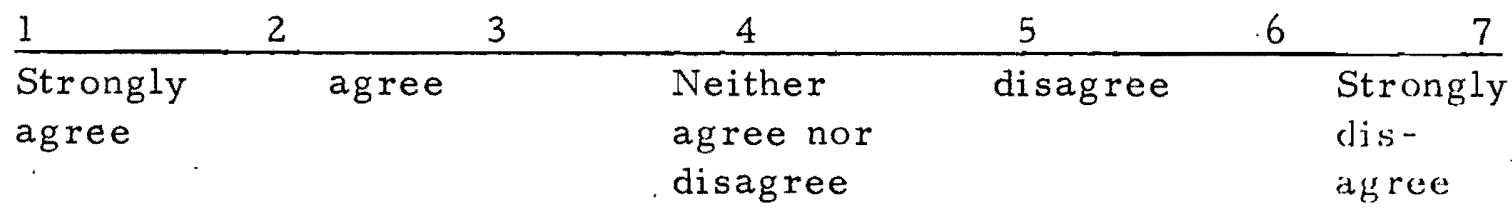


17. One of the principal efforts of youth workers should be centered around obtaining thorough psychological examinations of offenders before other plans are developed.

\begin{tabular}{lllllll}
1 & 2 & 3 & 4 & 5 & 6 & 7 \\
\hline $\begin{array}{llll}\text { Strongly } \\
\text { agree }\end{array}$ & agree & & $\begin{array}{l}\text { Neither } \\
\text { agree nor } \\
\text { disagree }\end{array}$ & disagree & Strongly \\
& & & & dis - \\
& & & & & agree
\end{tabular}

18. Workers should disseminate information on the injustices of the criminal justice system.

\begin{tabular}{lllllll}
1 & 2 & 3 & \multicolumn{1}{c}{4} & 5 & 6 & 7 \\
$\begin{array}{l}\text { Strongly } \\
\text { agree }\end{array}$ & agree & & $\begin{array}{l}\text { Neither } \\
\text { agree nor } \\
\text { disagree }\end{array}$ & disagree & $\begin{array}{l}\text { Strongly } \\
\text { dis - } \\
\text { agree }\end{array}$
\end{tabular}

19. A major function of workers should be to help develop community resources such as diversion centers, drop-in centers, and educational assistance programs for youth.

\begin{tabular}{lllllll}
1 & 2 & 3 & 4 & 5 & 6 & 7 \\
\hline $\begin{array}{llll}\text { Strongly } \\
\text { agree }\end{array}$ & agree & & $\begin{array}{l}\text { Neither } \\
\text { agree nor } \\
\text { disagree }\end{array}$ & disagree & $\begin{array}{l}\text { Strongly } \\
\text { dis - } \\
\text { agree }\end{array}$
\end{tabular}

20. Advocacy techniques should be used extensively in order to make organizations, such as schools, social services, and correctional facilities more receptive to the needs of youth.

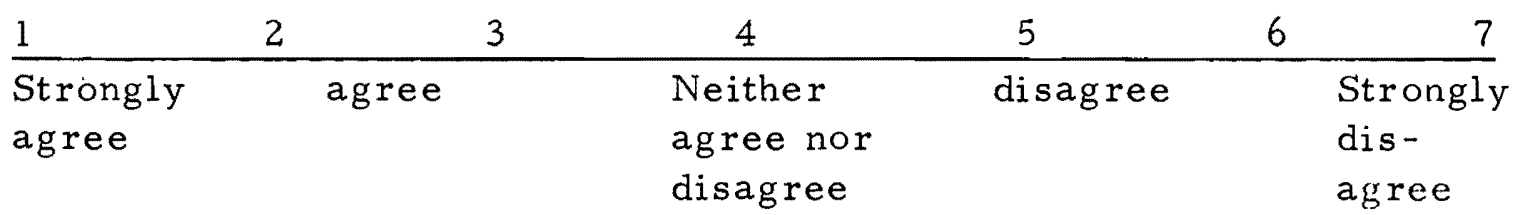

21. It is inappropriate for workers to permit offenders and their families to participate in probation and parole rule-setting, for their value system will conflict with those of youth.

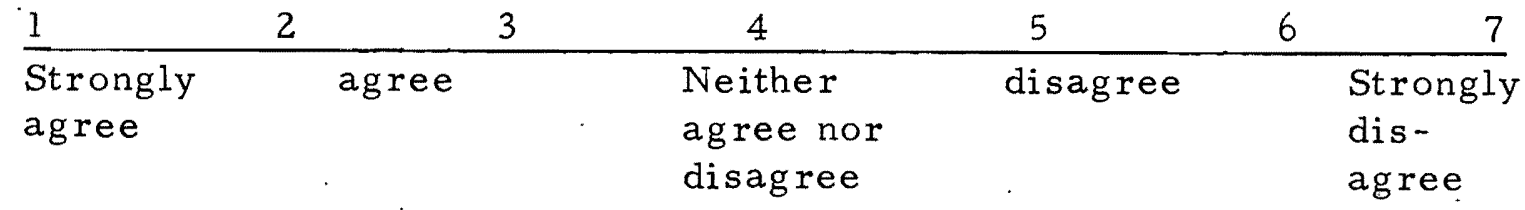


22. In many cases a youth worker inadvertently worsens the situation of an offender by becoming involved; therefore, the worker would best do nothing to offer the most useful service.

$\begin{array}{lllllll}1 & 2 & 3 & 4 & 5 & 6 & 7 \\ \begin{array}{l}\text { Strongly } \\ \text { agree }\end{array} & \text { agree } & & \begin{array}{l}\text { Neither } \\ \text { agree nor } \\ \text { disagree }\end{array} & \text { disagree } & \begin{array}{l}\text { Strongly } \\ \text { dis - } \\ \text { agree }\end{array}\end{array}$

23. Workers need to stress the importance of educational-training experiences for their clients so that they will be able to compete more effectively in the job market.

$\begin{array}{llllll}1 & 2 & 3 & 4 & 5 & 6 \\ \begin{array}{l}\text { Strongly } \\ \text { agree }\end{array} & \text { agree } & \begin{array}{l}\text { Neither } \\ \text { agree nor } \\ \text { disagree }\end{array} & \text { disagree } & \begin{array}{l}\text { Strongly } \\ \text { dis - } \\ \text { agree }\end{array}\end{array}$

24. It is extemely important for workers to inform clients of their legal rights and to see to it that their criminal rights are protected.

\begin{tabular}{|c|c|c|c|c|c|}
\hline 1 & 2 & 3 & 4 & 5 & 7 \\
\hline $\begin{array}{l}\text { Strongly } \\
\text { agree }\end{array}$ & agree & & $\begin{array}{l}\text { Neither } \\
\text { agree nor }\end{array}$ & disagree & $\begin{array}{l}\text { Strongly } \\
\text { dis- }\end{array}$ \\
\hline
\end{tabular}

25. Workers should assist delinquent youth in developing interpersonal and communication skills so that they can get along with others more effectively.

\begin{tabular}{|c|c|c|c|c|}
\hline 1 & 2 & 4 & 5 & 6 \\
\hline $\begin{array}{l}\text { Strongly } \\
\text { agree }\end{array}$ & agree & $\begin{array}{l}\text { Neither } \\
\text { agree nor } \\
\text { disagree }\end{array}$ & disagree & $\begin{array}{l}\text { Sirongly } \\
\text { dis- } \\
\text { agree }\end{array}$ \\
\hline
\end{tabular}

26. Workers should spend more time raising the consciousness level of their clients about delinquency than counseling them.

$\begin{array}{lllllll}1 & 2 & 3 & 4 & 5 & 6 & 7 \\ \begin{array}{llll}\text { Strongly } \\ \text { agree }\end{array} & \text { agree } & & \begin{array}{l}\text { Neither } \\ \text { agree nor } \\ \text { disagree }\end{array} & \text { disagree } & \begin{array}{l}\text { Strongly } \\ \text { dis - } \\ \text { agree }\end{array}\end{array}$


27. Youth workers should concentrate their efforts in the poorer districts of the community so that the youth there can receive needed counseling and other assistance.

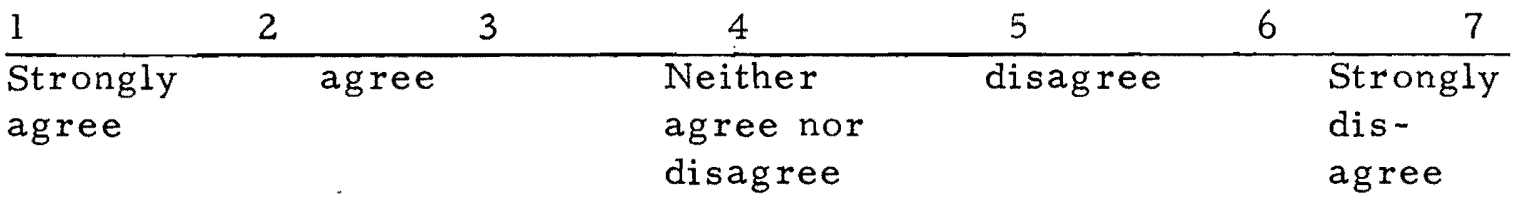

28. It is sound professional practice to interview and otherwise "work with" juvenile offenders in their neighborhoods and in their schools.

\begin{tabular}{lllllll}
1 & 2 & 3 & 4 & 5 & 6 & 7 \\
\hline $\begin{array}{llll}\text { Strongly } \\
\text { agree }\end{array}$ & agree & & $\begin{array}{l}\text { Neither } \\
\text { agree nor } \\
\text { disagree }\end{array}$ & disagree & Strongly \\
& & & & $\begin{array}{l}\text { dis - } \\
\text { agree }\end{array}$
\end{tabular}

29. Youth workers should know the resources of their community so that they can refer their clients for counseling and other services when they, themselves, cannot offer them.

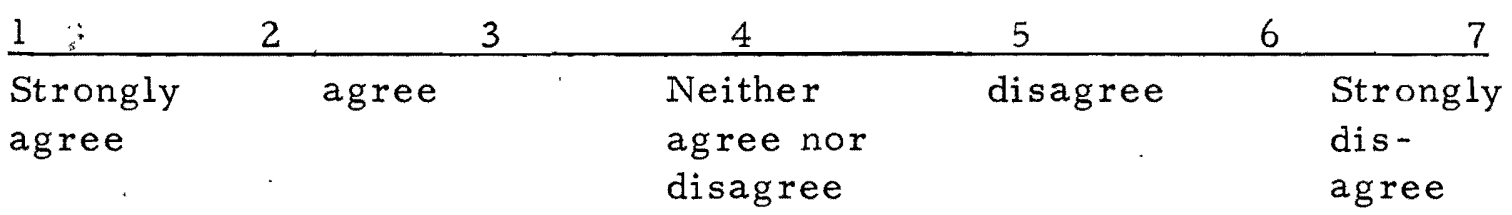

30. Linking clients to organizations, teaching them to get additional benefits if they are available and if not, attempting to change or alter the organization so that they will become available is a viable activity for youth workers.

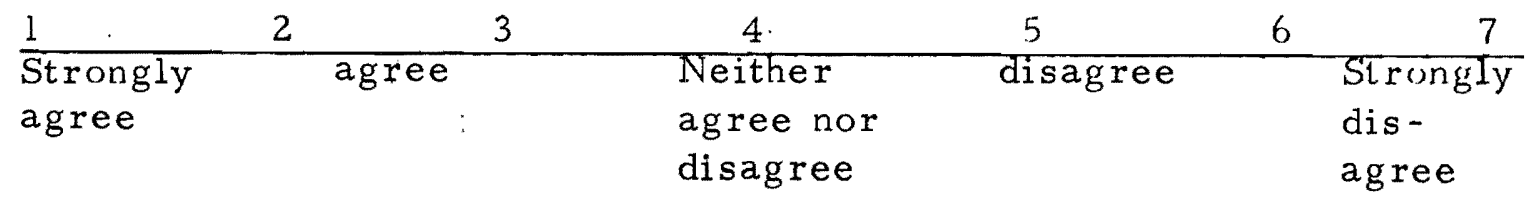

31. A first priority of workers should be to assist youth in preparing for and locating jobs rather than counseling the youth.

\begin{tabular}{|c|c|c|c|c|c|}
\hline 1 & 2 & 4 & 5 & 6 & 7 \\
\hline $\begin{array}{l}\text { Strongly } \\
\text { agree }\end{array}$ & & $\begin{array}{l}\text { Neither } \\
\text { agree nor } \\
\text { disagree }\end{array}$ & disagree & & $\begin{array}{l}\text { Strongly } \\
\text { dis- } \\
\text { agree }\end{array}$ \\
\hline
\end{tabular}


32. Workers should feel free to "bend" agency policies if they feel their actions will benefit the youth more.

\begin{tabular}{lllllll}
1 & 2 & 3 & 4 & 5 & 6 & 7 \\
\hline $\begin{array}{llll}\text { Strongly } \\
\text { agree }\end{array}$ & agree & & $\begin{array}{l}\text { Neither } \\
\text { agree nor } \\
\text { disagree }\end{array}$ & disagree & & $\begin{array}{l}\text { Strongly } \\
\text { dis - } \\
\text { agree }\end{array}$
\end{tabular}

33. Those who make delinquents "toe the line" and keep a watchful eye on their behavior get better results than those who are lenient.

\begin{tabular}{|c|c|c|c|c|c|c|}
\hline 1 & 2 & 3 & 4 & 5 & 6 & 7 \\
\hline $\begin{array}{l}\text { St rongly } \\
\text { agree }\end{array}$ & & & $\begin{array}{l}\text { Neither } \\
\text { agree nor } \\
\text { disagree }\end{array}$ & disagree & & $\begin{array}{l}\text { Strongly } \\
\text { dis- } \\
\text { agree }\end{array}$ \\
\hline
\end{tabular}




\section{APPENDIX II}

\section{REVISED QUESTIONNAIRE}

A new questionnaire is enclosed in the Appendix of this study in expectation that the new instrument will lead to a further refining of the theoretical framework.

The questions included in the new instrument are those items that had the highest factor loadings of the original questionnaire. The items also reflect most closely the hypothetical categories that the original questionnaire contained.

The advantages of the revised instrument are that it has been pre-tested and validated, and that it asks highly focused questions. 


\section{REVISED QUESTIONNAIRE}

Although we want to know something about your personal background, we are also very interested in your attitudes and beliefs about youth, and especially about delinquent youth. In particular, we are interested in your own personal views about the causes of delinquency, the types of programs needed to prevent delinquency, and the kinds of services which should be given to youth.

Let's take each of these one by one.

On the following pages is a series of statements related to the causes of delinquency. They are accompanied by an attitude scale ranging from 1 through 7 . The statements are intended to measure how much adjudicated delinquent behavior is at least partially explained by the statement. Notice that a one (1) means that you feel you strongly agree with the statement, while a seven (7) means that you strongly disagree. Read each statement and select which number best describes your position. Please circle your choice.

\section{THE CAUSE OF DELINQUENCY}

\section{$\underline{\text { Part } 1}$}

1. Biological factors such as brain abnormalities and chromosonal peculiarities play an important part in causing delinquency. (PIC)

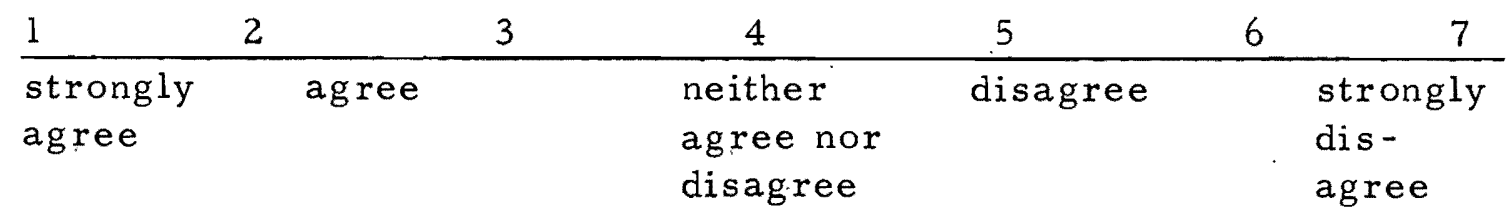

2. Innate aggression, if not channeled in a constructive way, is likely to manifest itself in delinquent behavior. (PIC)

\begin{tabular}{lllllll}
1 & 2 & 3 & 4 & 5 & 6 & 7 \\
\hline strongly & agree & & neither & disagree & & strongly \\
agree & & & $\begin{array}{l}\text { agree nor } \\
\text { disagree }\end{array}$ & & dis - \\
& & & & agree
\end{tabular}


3. Lower innate intelligence is an important factor in understanding delinquent behavior. (PIC)

\begin{tabular}{lllllll}
1 & 2 & 3 & 4 & 5 & 6 & 7 \\
\hline strongly & agree & & neither & disagree & & strongly \\
agree & & & agree nor & & & disagree \\
& & & & & agree
\end{tabular}

4. Poorly formed super-egos is a frequent cause of delinquency. (PIL)

\begin{tabular}{lllllll}
1 & 2 & 3 & 4 & 5 & 6 & 7 \\
\hline strongly & agree & & neither & disagree & & strongly \\
agree & & agree nor & & dis - \\
& & disagree & & agree
\end{tabular}

5. Delinquent youth frequently lack the ability to control anti-social impulses. (PIC)

\begin{tabular}{lllllll}
1 & 2 & 3 & 4 & 5 & 6 & 7 \\
\hline strongly & agree & & neither & disagree & & strongly \\
agree & & & agree nor & & dis - \\
& & disagree & & agree
\end{tabular}

6. A poor sense of morality leads to delinquent behavior. (PIL)

\begin{tabular}{lllllll}
1 & 2 & 3 & 4 & 5 & 6 & 7 \\
\hline strongly & agree & neither & disagree & strongly \\
agree & & agree nor & & dis - \\
& & disagree & & agree
\end{tabular}

7. Too much questioning of social institutions among the young has led to increased delinquency. (PIIC).

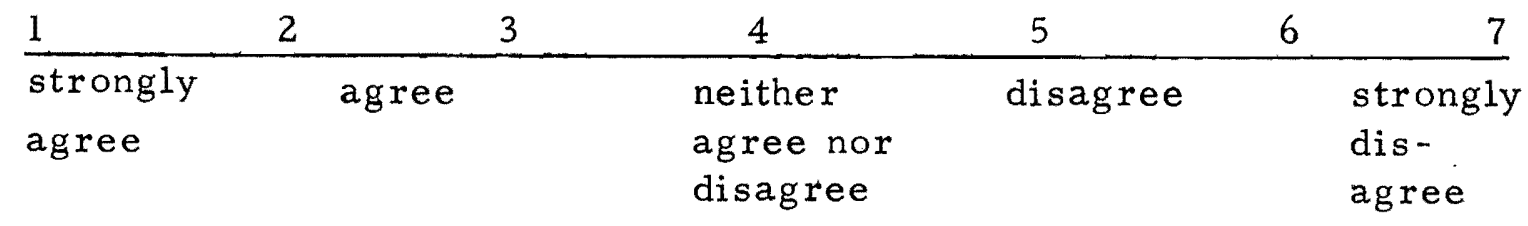

8. The lack of good parenting skills on the part of parents inadvertantly leads children into delinquency patterns. (PIIC)

\begin{tabular}{lllllll}
1 & 2 & 3 & 4 & 5 & 6 & 7 \\
\hline strongly & agree & & neither & disagree & strongly \\
agree & & agree nor & & dis - \\
& & disagree & & agree
\end{tabular}


9. Peer group pressure frequently causes delinquent behavior. (PIIC)

\begin{tabular}{lllllll}
1 & 2 & 3 & 4 & 5 & 6 & 7 \\
\hline $\begin{array}{l}\text { strongly } \\
\text { agree }\end{array}$ & agree & & $\begin{array}{l}\text { neither } \\
\text { agree nor } \\
\text { disagree }\end{array}$ & disagree & strongly \\
& & & & $\begin{array}{l}\text { dis - } \\
\text { agree }\end{array}$
\end{tabular}

10. The size, complexity and impersonality of most public schools inadvertantly fosters delinquency. (PIIL)

$\begin{array}{lllllll}1 & 2 & 3 & 4 & 5 & 6 & 7 \\ \begin{array}{l}\text { strongly } \\ \text { agree }\end{array} & \text { agree } & & \begin{array}{l}\text { neither } \\ \text { agree nor } \\ \text { disagree }\end{array} & \text { disagree } & & \begin{array}{l}\text { strongly } \\ \text { dis - } \\ \text { agree }\end{array}\end{array}$

11. A lack of job opportunities for youth is important in generating delinquency. (PIIL)

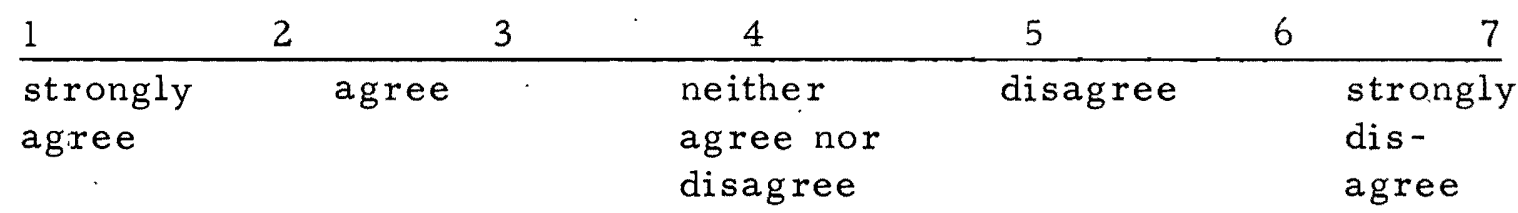

12. Delinquency is caused by a breakdown in community relations indlucing dysfunctional schools and neighborhoods. (PIIL)

$\begin{array}{llllll}1 & 2 & 3 & 4 & 5 & 6 \\ \begin{array}{lll}\text { strongly } \\ \text { agree }\end{array} & \text { agree } & \begin{array}{l}\text { neither } \\ \text { agree nor } \\ \text { disagree }\end{array} & \text { disagree } & \begin{array}{l}\text { strongly } \\ \text { dis - } \\ \text { agree }\end{array}\end{array}$

13. The causes of delinquency are ultimately to be found in the com-. petitive norms and values of our economic institutions. (PIIR)

\begin{tabular}{lllllll}
1 & 2 & 3 & 4 & 5 & 6 & 7 \\
\hline $\begin{array}{llll}\text { strongly } \\
\text { agree }\end{array}$ & agree & & $\begin{array}{l}\text { neither } \\
\text { agree nor } \\
\text { disagree }\end{array}$ & & disagree & strongly \\
& & & & dis - \\
& & & & agree
\end{tabular}


14. There are no real psychological differences between delinquent and non-delinquent youth. (PIIR)

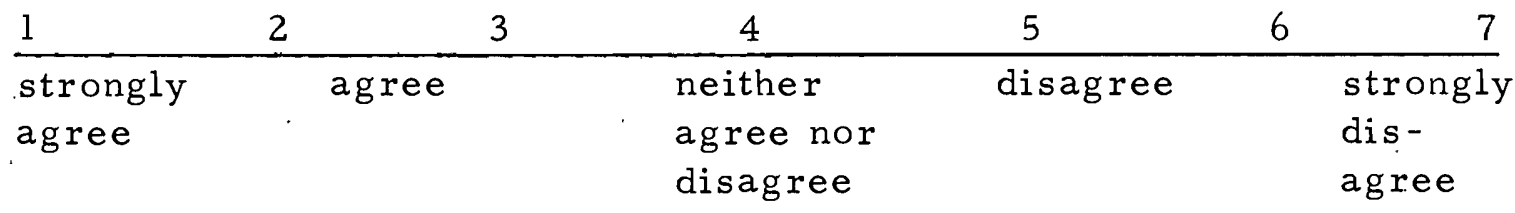

15. To the extent that capitalizm can not function without a poverty or near poverty class it contributes importantly to the creation of delinquency. (PIIR)

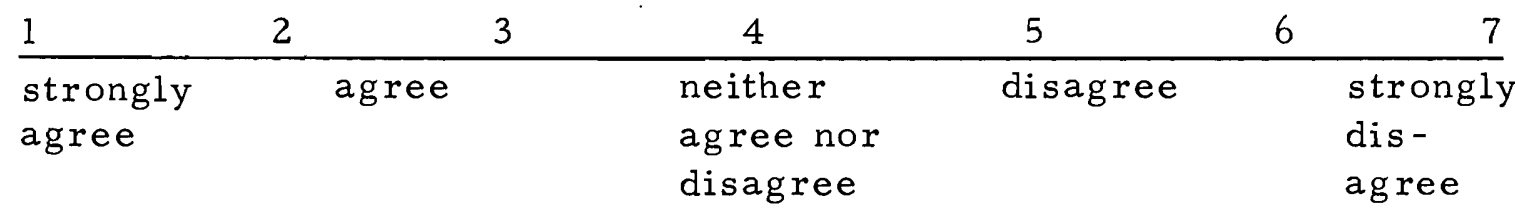

Part II

Here is another attitude scale. Note that a one (1) on this scale means that you strongly agree with the statement, while a seven (7) means that you strongly oppose the statement.

PROGRAM AND POLICY CONSIDERATIONS

16. Although we should try to help all youth many are so set in their ways that little can be done to change them. (PIC)

\begin{tabular}{lllllll}
1 & 2 & 3 & 4 & 5 & 6 & 7 \\
\hline strongly & agree & & neither & disagree & & strongly \\
agree & & & agree nor & & & dis - \\
& & & & & agree
\end{tabular}

17. The heart of a delinquency program is good individual and family casework or counseling. (PIL)

\begin{tabular}{lllllll}
1 & 2 & 3 & 4 & 5 & 6 & 7 \\
\hline strongly & agree & & neither & disagree & strongly \\
agree & & agree nor & & dis - \\
& & & & agree
\end{tabular}


18. Programs for youth should aim to be supportive of the emotional needs of youth. (PIL)

\begin{tabular}{lllllll}
1 & 2 & 3 & 4 & 5 & 6 & 7 \\
\hline strongly & agree & & neither & disagree & & strongly \\
agree & & agree nor & & dis - \\
& & disagree & & agree
\end{tabular}

19. Delinquent youth are best served by programs that stress practical methods for competing in the work world. (PIL)

\begin{tabular}{lllllll}
1 & 2 & 3 & 4 & 5 & 6 & 7 \\
\hline strongly & agree & & neither & disagree & & strongly \\
agree & & & agree nor & & & disagree \\
& & & & agree
\end{tabular}

20. Counseling programs which help youth gain a greater critical understanding of our society could best serve the needs of youth. (PIR)

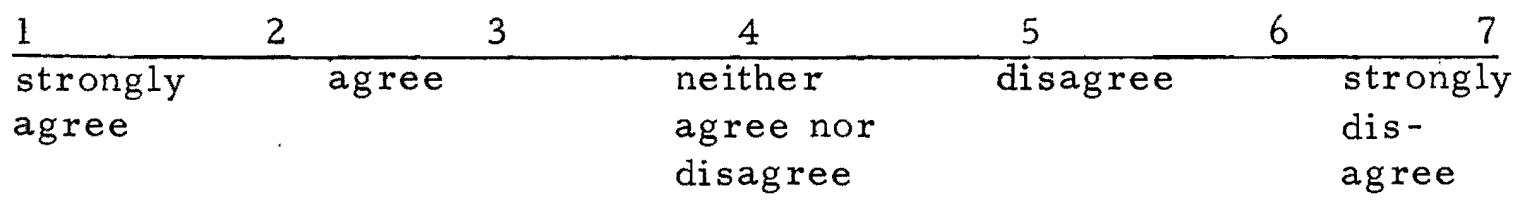

21. The traditional values of family life should be supported by social service programs. (PIIC)

\begin{tabular}{lllllll}
1 & 2 & 3 & 4 & 5 & 6 & 7 \\
\hline strongly & agree & & $\begin{array}{l}\text { neither } \\
\text { agree }\end{array}$ & & & disagree nor \\
disagree & & & strongly \\
& & & & dis - \\
agree
\end{tabular}

22. When delinquency programs fail it is usually because there is a lack of community resources to help youth and their families overcome their problems. (PIIL)

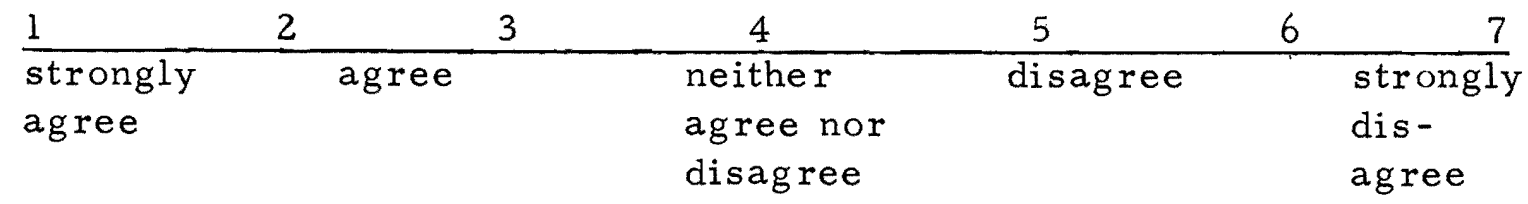


23. Programs should be designed to encourage the business community to increase employment opportunities for youth. (PIIL)

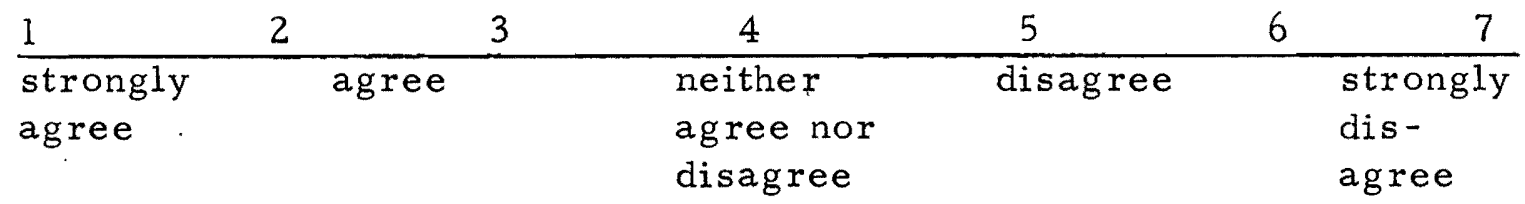

24. Youth programs should work closely with the schools, especially for the early detection of potentially delinquent children. (PIIL)

\begin{tabular}{lllllll}
1 & 2 & 3 & 4 & 5 & 6 & 7 \\
\hline strongly & agree & & neither & disagree & strongly \\
agree & & & agree nor & & & dis - \\
& & & & & agree
\end{tabular}

25. It is unlikely that any youth service can really eliminate delinquency. (PIIR)

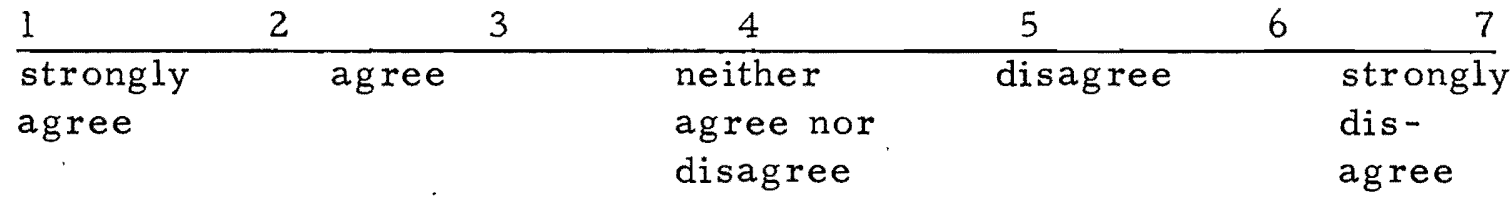

26. To a considerable extent, delinquents would be best served if policies were adopted that accepted greater diversity in youth behavior and narrowed exceedingly special delinquency law. (PIIR)

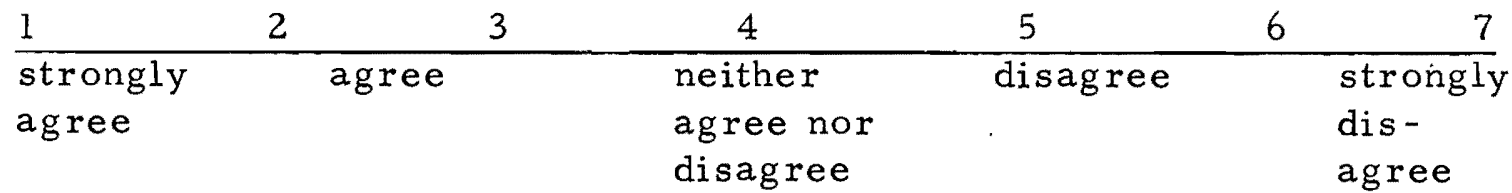

27. Every child should have the right to refuse treatment. (PIIR)

\begin{tabular}{lllllll}
1 & 2 & 3 & 4 & 5 & 6 & 7 \\
\hline strongly & agree & & neither & disagree & strongly \\
agree & & agree nor & & dis - \\
& & disagree & & agree
\end{tabular}


$\underline{\text { Part III }}$

Please continue as before. Remember that a one (1) means that you strongly agree with a statement, and a seven (7) that you strongly disagree.

\section{ROLE OF THE WORKER}

28. Workers should always stay within agency guidelines since they were developed in the best interests of youth. (PIC)

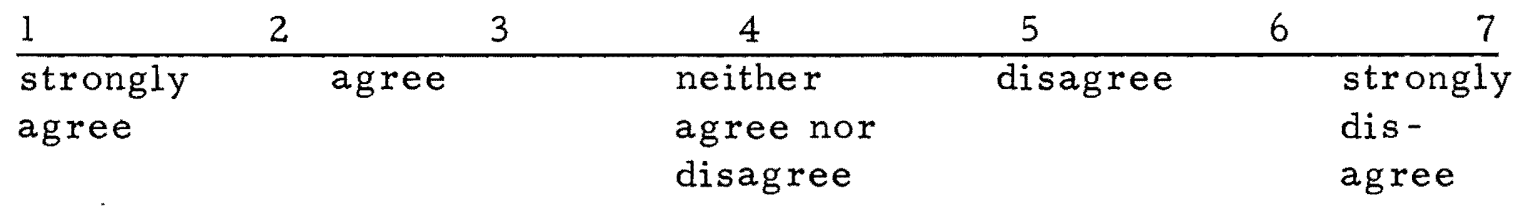

29. Self-responsibility is an important goal for workers to stress to their clients. (PIL)

\begin{tabular}{|c|c|c|c|c|c|c|}
\hline 1 & 2 & 3 & 4 & 5 & 6 & 7 \\
\hline strongly & & & neither & disagree & & strongly \\
\hline agree & & & $\begin{array}{l}\text { agree nor } \\
\text { disagree }\end{array}$ & & & $\begin{array}{l}\text { dis - } \\
\text { agree }\end{array}$ \\
\hline
\end{tabular}

30. Workers need to stress the importance of education/training experiences for their clients so that they will be able to compete more effectively in the job market. (PIL)

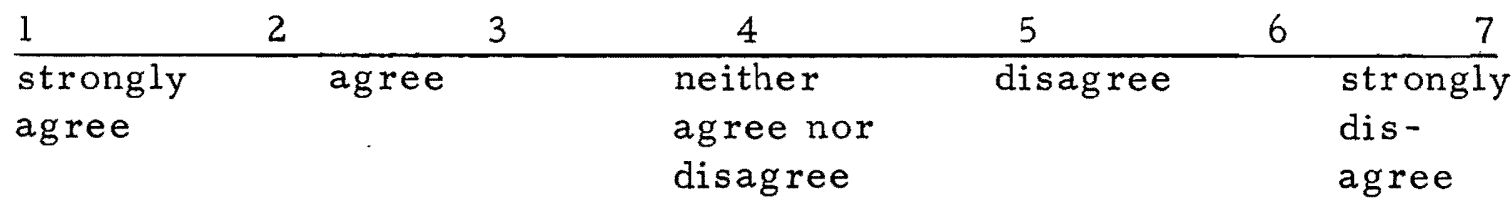

31. Workers should assist delinquent youth in developing interpersonal and communication skills so that they can get along with others more effectively. (PIL)

\begin{tabular}{|c|c|c|c|c|c|}
\hline 1 & 2 & 4 & 5 & 6 & 7 \\
\hline strongly & & neither & disagree & & $\overline{\text { strongly }}$ \\
\hline agreed & & $\begin{array}{l}\text { agree nor } \\
\text { disagree }\end{array}$ & & & $\begin{array}{l}\text { dis- } \\
\text { agree }\end{array}$ \\
\hline
\end{tabular}


32. Workers should help offendexs to understand that their misconduct is not the result of neurosis and bad mental health, but rathe $r a$ function of blocked opportunity. (PIR)

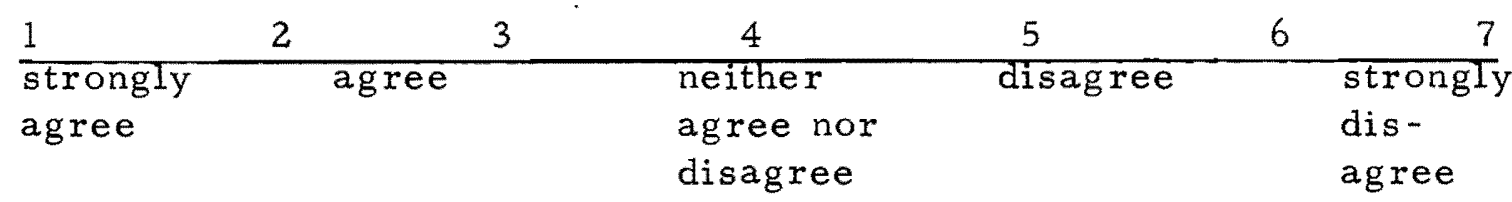

33. Workers should stress the traditional values of family solidarity and responsibility since much delinquent behaviox is a function of the breakdown of these values. (PIIC)

\begin{tabular}{lllllll}
1 & 2 & 3 & 4 & 5 & 6 & 7 \\
\hline $\begin{array}{llll}\text { strongly } \\
\text { agree }\end{array}$ & agree & & $\begin{array}{l}\text { neither } \\
\text { agree nor } \\
\text { disagree }\end{array}$ & disagree & $\begin{array}{l}\text { strongly } \\
\text { dis - } \\
\text { agree }\end{array}$
\end{tabular}

34. Effective workers should stress the "old" values, since such values still represent the backbone of this society. (PIC)

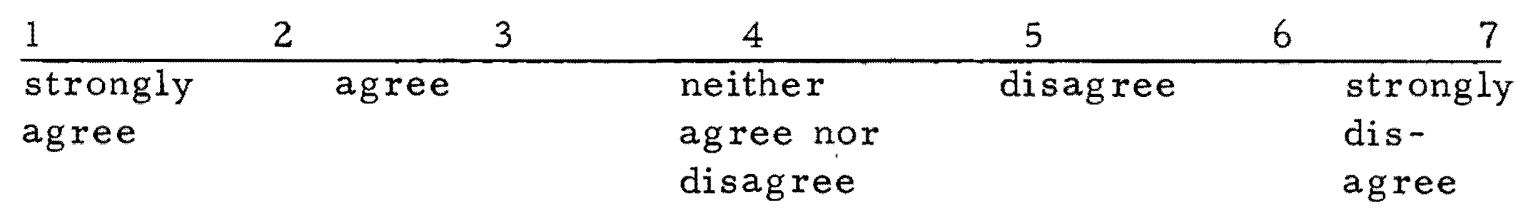

35. Workers have a responsibility to talk with business people about the role of business in helping delinquents. (PIIL)

\begin{tabular}{|c|c|c|c|c|c|c|}
\hline 1 & 2 & 3 & 4 & 5 & 6 & 7 \\
\hline $\begin{array}{l}\text { strongly } \\
\text { agree }\end{array}$ & & & $\begin{array}{l}\text { neither } \\
\text { agree nor } \\
\text { disagree }\end{array}$ & disagree & & $\begin{array}{l}\text { strongly } \\
\text { dis - } \\
\text { agree }\end{array}$ \\
\hline
\end{tabular}

36. Workers should devote considerable attention to the development of job opportunities for delinquent youth. (PIIL)

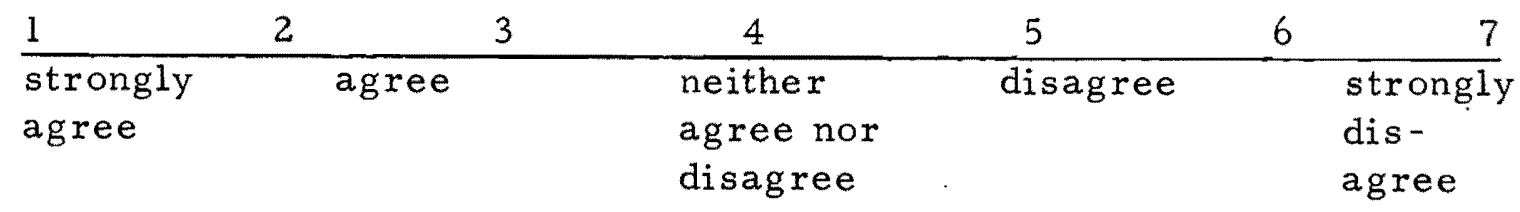


37. Linking clients to organizations, teaching them to get additional benefits if they are a vailable and if not, attempting to change or alter the organization so that they will become available is a viable activity for youth workers. (PIIL)

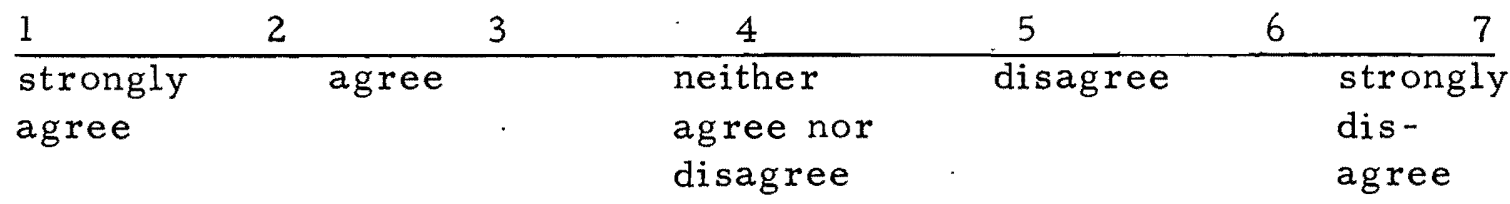

38. Youth workers would best help delinquents by involving themselves wholeheartedly in legitimate political activities aimed at producing a more equitable society. (PIIR)

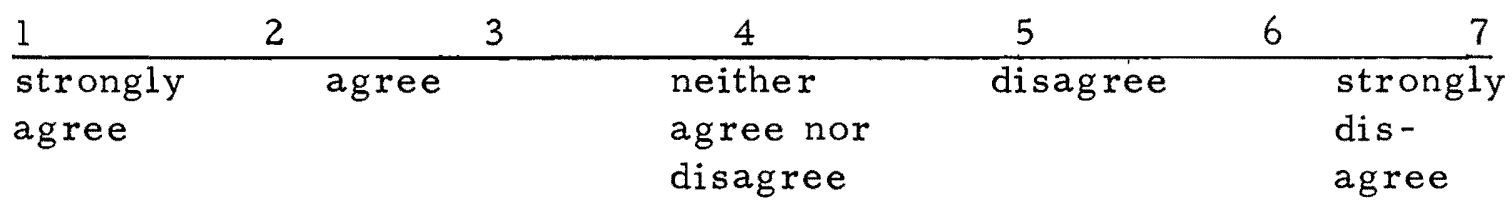

39. Any worker should feel free to organize other workers around the issue of understanding the rights of offenders and be prepared to advocate the fulfillment of those rights. (PIIR)

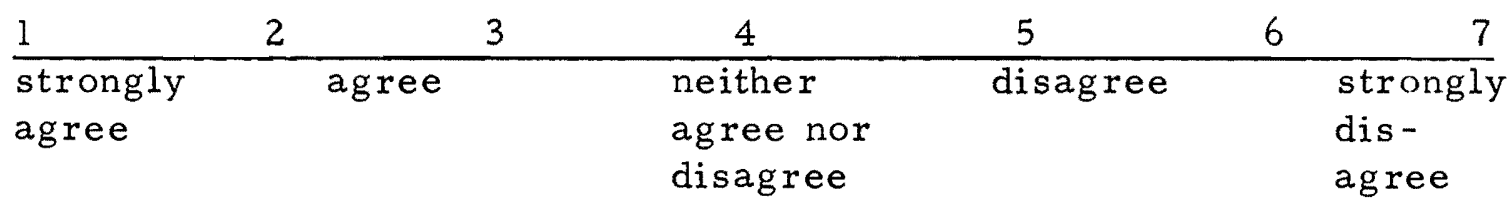

40. Workers should disseminate information on the injustices of the criminal justice system. (PIIR)

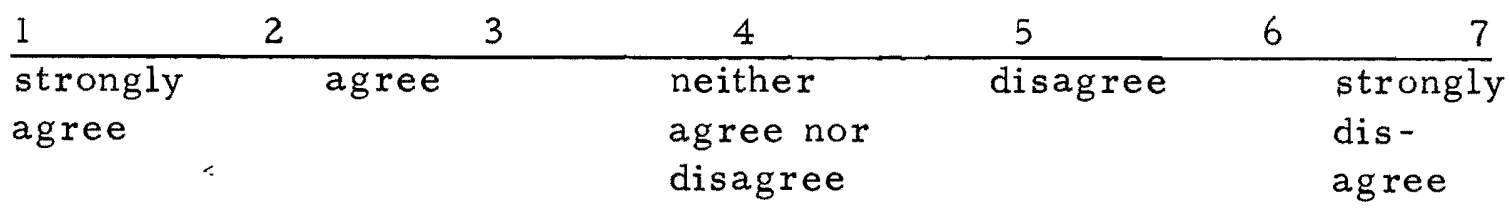


Mr. Graham Tewksbury, Director

Columbia County Juvenile Department

Old Court House

St. Helens, OR 97051

Dear Mr. Tewksbury,

We are requesting your assistance in administering a questionnaire about attitudes of juvenile workers towards the causes, programs, and role of the worker in regards to juvenile delinquency. We are conducting this research to gain further knowledge about attitudes of workers in this area towards their clients and programs.

Dr. Norman Wyers, PSU School of Social Work, our advisor for this research has suggested that we contact you. We would like to arrange with you a convenient time at which we could administer the questionnaire to your staff; completing the questionnaire should take about 30 minutes. Perhaps this could be best accomplished during a scheduled staff meeting for the convenience of the workers and to insure validity of our research.

We will be contacting you by telephone within the next week to see if time can be arranged with you for administering this questionnaire. If you have further questions regarding this request, Dr. Wyers will be available at the PSU School of Social Work, 229-4712.

Sincerely,

Michael O. Taylor

Graduate Student

School of Social Work
Gary L. Dominick

Graduate Student

School of Social Work

$M T: G D: j l r$ 